\title{
Evangelical Responses \\ to the Question of Religious Pluralism
}

By

\section{Cecily May Worsfold}

\author{
A thesis \\ submitted to the Victoria University of Wellington \\ in fulfilment of the \\ requirements for the degree of \\ Master of Arts \\ In Religious Studies
}

Victoria University of Wellington

2011 


\begin{abstract}
The relatively recent rise of religious pluralism has significantly affected the evangelical movement, the roots of which are traceable to the sixteenth century Reformation. In particular, the theological implications of religious pluralism have led to debate concerning the nature of core beliefs of evangelicalism and how these should be interpreted in the contemporary world. While evangelicals continue to articulate a genuine undergirding desire to "honour the authority of Scripture", differing frameworks and ideals have led to a certain level of fracturing between schools of evangelical thought.
\end{abstract}

This research focuses on the work of three evangelical theologians - Harold Netland, John Sanders and Clark Pinnock - and their responses to the question of religious pluralism. In assessing the ideas put forward in their major work relevant to religious pluralism this thesis reveals something of the contestation and diversity within the evangelical tradition. The authors' respective theological opinions demonstrate that there is basic agreement on some doctrines. Others are being revisited, however, in the search for answers to the tension between two notions that evangelicals commonly affirm: the eternal destiny of the unevangelised; and the will of God that all humankind should obtain salvation. Evangelicals are deeply divided on this matter, and the problem of containing seemingly incompatible views within the confines of "evangelical belief" remains. This ongoing division highlights the difficulty of defining evangelicalism in purely theological terms. 


\section{ACKNOWLEDGEMENTS}

Sincere thanks are due to Dr Geoff Troughton, Religious Studies programme at Victoria University of Wellington, for his assistance in the initial stages of the project and, more importantly, for continuing supervision and advice.

I especially thank Professors Harold Netland and John Sanders, U.S.A., for their prompt and willing responses to my appeals for biographical information which was unavailable from any other source.

Members of my family have been interested, particularly Luke, who found time in his own busy schedule to listen, and encourage. From time to time, my lack of computer skills has required Renee's patient "talking through" a procedure even though from a distance of two and a half thousand kilometres. My thanks are given to them all. 


\section{TABLE OF CONTENTS}

ABSTRACT

ACKNOWLEDGEMENTS

TABLE OF CONTENTS 1

CHAPTER ONE: INTRODUCTION 3

$\begin{array}{ll}\text { Religious Pluralism } & 5\end{array}$

Evangelicalism $\quad 9$

$\begin{array}{ll}\text { Methodology and Overview } & 12\end{array}$

CHAPTER TWO: HAROLD A. NETLAND, EXCLUSIVIST 16

$\begin{array}{ll}\text { Biographical } & 16\end{array}$

$\begin{array}{ll}\text { Exclusivism } & 19\end{array}$

Explaining the Drift from Exclusivism $\quad 26$

$\begin{array}{ll}\text { Cornerstone Exclusivist Doctrines } & 29\end{array}$

$\begin{array}{ll}\text { Further Issues at Stake } & 40\end{array}$

$\begin{array}{ll}\text { Summary } & 47\end{array}$

CHAPTER THREE: JOHN E. SANDERS, INCLUSIVIST 50

$\begin{array}{ll}\text { Biographical } & 50\end{array}$

$\begin{array}{ll}\text { Inclusivist Considerations } & 53\end{array}$

Universally Accessible Salvation versus Universalism 65

$\begin{array}{ll}\text { Open Theism } & 68\end{array}$

$\begin{array}{ll}\text { Summary } & 83\end{array}$

CHAPTER FOUR: CLARK H. PINNOCK, RADICAL INCLUSIVIST 87

$\begin{array}{ll}\text { Biographical } & 88\end{array}$

$\begin{array}{ll}\text { Inclusivism and its Appeal } & 91\end{array}$

The Wider Hope $\quad 96$

$\begin{array}{ll}\text { Summary } & 120\end{array}$ 
CHAPTER FIVE: CONCLUSION

BIBLIOGRAPHY 


\section{Chapter One}

\section{INTRODUCTION}

Since the late nineteenth century the increased diversity in Western societies, both cultural and religious, has generated a series of significant challenges for evangelical theology. Religious pluralism has become more acute during the twentieth and twenty-first centuries. Aspects of it have been embraced by some evangelical theologians as a potential solution to problems confronting Christianity. Engagement with religious pluralism has in turn produced discussion on a range of theological questions that have considerable practical significance. These questions include matters pertaining to Christian understandings of the atonement, the nature and scope of salvation, the place of conversion, and the status of non-Christian religions. Debates have become widespread within the evangelical community, and theologians have been prolific in publishing a range of views.

This thesis argues that, historically, evangelicals viewed their faith as simply orthodox Christianity, and the movement was marked by a high degree of theological coherence. The debate about pluralism provides key insights into the subsequent fracturing of this theological connectedness within evangelicalism. Arguably, pluralism and related debates, and the theological issues arising from them, have played a central role in the process of fragmentation.

Christian responses to challenges posed by religious pluralism are addressed in the work of three contemporary theologians - Harold Netland, John Sanders and Clark Pinnock - all of whom identify with the evangelical tradition. Their theological 
standpoints are explored and their responses to religious pluralism traced, indicating something of the immense breadth of evangelicalism. In terms of the question of religious pluralism, they can be placed at various points on the spectrum associated with three schools of thought that are often referred to as "exclusivism" (or "particularism"), "inclusivism," and "pluralism."

The writings of Netland, Sanders and Pinnock may be seen as a defence of traditional evangelicalism, or as presenting possible answers to the problem of the scope of salvation and atonement. Their work reveals deep doctrinal divisions within the wider evangelical movement. Evangelicals resist religious pluralism as an unqualified position, and numerous controversies have arisen where aspects of pluralistic ideas have been espoused. Notions of a "wider hope" and "open theism," for example, have attracted some theologians. Others consider that these arguments disturb fundamental tenets of Christian faith including classical understandings of the doctrine of God. The question as to whether God's love revealed in Jesus Christ may be experienced in the context of non-Christian religions has been contentious. Notions of salvation without specific knowledge of Christ, and rejection of the idea that one's eternal destiny is determined at the point of death, also impinge on distinctive evangelical emphases.

While contemporary evangelical theologians denounce religious pluralism as propounded by its leading exponents, there has emerged significant diversity within the evangelical movement on questions which relate to pluralistic ideas. The latitude given to proposed answers to contemporary questions on the doctrine of God, salvation, the final destiny of the unbeliever, and the authority of Scripture will be 
examined. The theological ground of historical evangelicalism shows signs of widening fissures which raise questions for its future as a theologically connected, unified and distinctive movement.

\section{Religious Pluralism}

There is a clear link between the increasingly liberal attitude towards other cultures and faiths within Western societies and the non-acceptance of traditional evangelical claims. During the twentieth century, public opinion increasingly encouraged and affirmed diversity in multi-ethnic communities. In keeping with this emphasis, some theological reflection became more uncomfortable with appearing to deny the sincerity of non-Christians in following their religions, or the salvific efficacy of their traditions. It became unacceptable to insist on traditional Christianity's truth claims of the authority of Scripture, salvation through Jesus Christ the only Saviour, and God's final judgment of all humanity. The offensiveness of these claims followed from social pluralism's demand for tolerance of all other views. One sociological analysis published in 1987 showed that the "ethic of civility," that is, the effort to be "tolerable" to others, was adversely affecting evangelicalism. While the latter was granted a legitimate place in the public arena, the ethic of civility blunted the edges of the theological "offensive" doctrines hitherto held by evangelicals. ${ }^{1}$

The fact of increased pluralism in society, and shifts in public attitudes, constitute one dimension of the challenge to evangelical theology. This thesis is primarily concerned, however, with religious pluralism as a particular doctrine. Religious

\footnotetext{
${ }^{1}$ James Davison Hunter, Evangelicalism: The Coming Generation (Chicago: University of Chicago Press, 1987), 34-40.
} 
pluralism of this kind is often associated with the views espoused by writers like John Hick, and may be contrasted with the exclusivism and inclusivism favoured by evangelicals.

\section{(1) All Traditions Lead to God}

Hick is widely recognised as the most vigorous exponent of religious pluralism, and has presented a case for normative religious pluralism since $1972 .^{2} \mathrm{He}$ is an influential writer who has caused much concern among evangelical theologians due to his proposals to solve the question of the universal salvific will of God. Hick considers that all religions lead to the same God. Therefore, he calls for a separation of the "Christ principle" from the "Christ event," which is uniquely Christian. The former, Hick argues, is available to all religious traditions, and although each has its own distinctive emphases, the traditions are equally valid.

Hick's model of religious pluralism argues for three claims: that there is an ultimate reality to which the different religions are legitimate responses; that the various religions are historically and culturally conditioned interpretations of this reality; that the soteriological transformation is occurring roughly to the same extent within the

\footnotetext{
${ }^{2}$ Dennis L. Okholm and Timothy R. Phillips, "Introduction," in More Than One Way? Four Views on Salvation in a Pluralistic World, ed. Dennis L. Okholm and Timothy R. Phillips (Grand Rapids: Zondervan, 1995), 13. John Hick was born in Scarborough, Yorkshire, in 1922. He converted to Christianity in 1940, and joined the evangelical InterVarsity Fellowship while studying Law at University College, Hull. His first "noticeable" departure from conservative theology occurred while at Princeton Theological Seminary, 1961, where he "questioned whether belief in the incarnation required one to believe in the literal historicity of the Virgin Birth." John Hick, "A Pluralist View," in More Than One Way? Four Views on Salvation in a Pluralistic World, ed. Dennis L. Okholm and Timothy R. Phillips (Grand Rapids: Zondervan, 1995), 32.
} 
major religions. ${ }^{3}$ Hick formerly held evangelical doctrines, and although he claims to remain Christian, he repudiates any notion that the uniqueness of Christ implies that Christ is the only Saviour. He accepts that Jesus is unique, but only for him and fellow Christians, "while others have their own independent insight into God."4

Over a period of some decades Hick has developed from his initial adoption of what Netland describes as a "vague theism" (the "Eternal One") to the use of the "Real" to denote the "religious ultimate." Salvation, for him, is a transformation from selfcentredness to Reality-centredness. ${ }^{6}$ He argues that other religions provide salvific access to the Real. "Christianity is not the one and only salvific path, but is one among others."

\section{(2) The Incarnation as Metaphor}

Religious pluralism questions a number of distinctive and foundational Christian doctrines - the incarnation, the atonement and the triune God, for example. The two natures of Christ, divine and human, are related to these. The Christian doctrine maintains that Jesus was fully divine and fully human. It has typically been assumed that the former, to be genuine, must possess all the attributes that define deity, including omnipotence, omnipresence and omniscience. Humanity must, likewise,

\footnotetext{
${ }^{3}$ Netland, Encountering Religious Pluralism: The Challenge to Christian Faith and Mission (Downers Grove, IL.: InterVarsity Press, 2001), 221.

${ }^{4}$ Okholm and Phillips, "Introduction," 18.

${ }^{5}$ Netland, Encountering Religious Pluralism, 169.

${ }^{6}$ Hick, “A Pluralist View," 44.

${ }^{7}$ Ibid., 52.
} 
possess all the attributes of a human being. Hick observes that the Council of Chalcedon (451 A.D.) never explained how this could be so. In his view the incarnation is merely a metaphor.

\section{(3) Morality and Salvation}

Hick rejects the view of conservative evangelicals who would differentiate between morality and salvation. His observations hinge largely on his perception of "salvation" which, he believes, is happening in all the world religions. Religious pluralism opens the door to the idea that salvation can be found in non-Christian religions, and that knowledge of God's provision of atonement for sin through the death of Christ is unnecessary. It endeavours to find a path between God's will to save all humankind and the belief that salvation is found only in Christ. Thus an attempt is made to avoid any attitude of elitism.

For Hick, a change from human selfishness (the cause of all evil) to a transformation centred in God, defines salvation. Some theologians offer answers built on emotional grounds, or by rules of morality. God's impartiality is brought into question if there is no alternative way to attain salvation. The final destiny of those who have never heard the gospel is the question that arises. "Religious pluralists," explains Netland, "repudiate the suggestion that there is anything superior, normative, or definitive about Christianity. Christian faith is merely one of the many equally legitimate human responses to the same divine reality."8

\footnotetext{
${ }^{8}$ Harold Netland, Dissonant Voices: Religious Pluralism and the Question of Truth (Vancouver, BC.: Regent College Publishing, 1997), 10.
} 


\section{Evangelicalism}

Evangelicals distinguish themselves from religious pluralists on this fundamental set of issues. As one recent interpreter notes, those who call themselves "evangelical" are "gospel (evangel) people," committed to a theology that John Stott asserts "goes back beyond the Reformation to the Bible itself." ${ }^{10}$ Historically, the ethos of evangelicalism can be traced from apostolic days to the Great Awakenings in North America, and in the revivalism of the nineteenth and early-twentieth centuries which spread through Britain, Europe and America. The roots of the evangelical movement are found in the sixteenth century Reformation. Although not a word found in Scripture, "evangelical" is derived from the Greek euangelion meaning "good news" which is clearly enunciated in the New Testament. As a term, "evangelicalism" has been in usage since the mid-eighteenth century when it referred to Christian communities within Protestant churches who were dedicated to "spreading the gospel."11

Theologically, evangelicalism (particularly in its Calvinistic forms) has laid emphasis on the sovereignty of God, obedience to the authority of Scripture, a personal experience of salvation through Christ's work on the cross, and the hope of Christ's visible return to rule the world in righteousness. Evangelicals generally

\footnotetext{
${ }^{9}$ Kevin J. Vanhoozer, “The Triune God of the Gospel," in The Cambridge Companion to Evangelical Theology, ed. Timothy Larsen and Daniel J. Treier (Cambridge: Cambridge University Press, 2007), 17.

${ }^{10}$ John R. W. Stott, Christ the Controversialist (London: Tyndale Press, 1970), 32.

${ }^{11}$ David W. Bebbington, Evangelicalism in Modern Britain: A History from the 1730s to the $1980 \mathrm{~s}$ (Oxford: Routledge, 1989), 1-2.
} 
adhere to orthodox Christian doctrines based on agreement with the early creedal confessions of the church. Commitment to maintain the supremacy of Scripture leads them to accept, with other Protestants, the sacraments of water baptism and the Lord's Supper.

Among the many definitions of evangelicalism one of the better known is given by Bebbington. He lists four "qualities": (a) "conversionism, the belief that lives need to be changed; (b) activism, the expression of the gospel in effort; (c) biblicism, a particular regard for the Bible; and (d) what may be called crucicentrism, a stress on the sacrifice of Christ on the cross."12 The second quality in Bebbington's list would be regarded by evangelicals as the expected outcome of the other three. According to the Statement of Faith of the Evangelical Alliance, founded in 1846, the human race is lost in sin. Only by the atoning death of Jesus Christ and his resurrection, and the work of the Holy Spirit, can there be any grounds for the individual's justification and salvation. The conversion experience need not be located in a particular date and time, but must be a genuine experience of repentance, and faith in Christ, nevertheless. ${ }^{13}$

The widespread desire for conversions to occur in prayer and preaching meetings, led to a focus on personal witness. This was considered to be the Christian's duty in spreading the gospel message both at home and on the "mission field." The Protestant missionary movement of the eighteenth and nineteenth centuries was a

\footnotetext{
${ }^{12}$ Bebbington, Evangelicalism in Modern Britain, 3.

${ }^{13}$ See http://www.worldevangelicals.org/aboutwea/statementoffaith.htm (accessed 29 June, 2010).
} 
result of these convictions. The Scriptural mandate of mission to all peoples is a continuing evangelical concern.

Historically, evangelicals considered reliance on the rites and rituals of the church to dispense God's grace to be insufficient, since it could not procure a "change of heart" and true regeneration. Therefore, they pulled away from the churchgoing respectability of "nominalism" and emphasised "heart experience." Evangelicals viewed ceremonies without personal understanding to be devoid of spiritual value. Therefore, the practice of infant baptism as a vehicle of regeneration was largely rejected. $^{14}$

Beliefs such as those listed here have remained basic to evangelicalism. There is no little concern among traditional evangelicals that the core of evangelical belief is under stress. While some are committed to historical views, others who also bear the name of evangelical question some of the basic doctrines. Disagreement has ensued, and continues to grasp the attention of evangelical communities and theologians alike. Many traditional notions are contested (by theologians especially), and the diversity now existing within evangelicalism - which has implications for the continuation of the movement - is thrown into sharp relief.

\footnotetext{
${ }^{14}$ G. W. Bromiley, "Infant Baptism," in Evangelical Dictionary of Theology, ed. Walter A. Elwell, $2^{\text {nd }}$ ed. (Grand Rapids: Baker Academic, 2009), 133. Exclusive Brethren, for example, practice baptism by immersion for infants of parents in fellowship with the community, on the grounds that it is not forbidden in Scripture. It is expected that a confession of faith will be made when the child reaches an age of understanding.
} 


\section{Methodology and Overview}

The methodology of this study is based on a close reading of the three evangelical theologians named above. Their respective writings are treated as examples of exclusivist, inclusivist and radical inclusivist (or pluralistic inclusivist) positions within evangelicalism. Discussions have evolved from the diverse viewpoints, and are presented by the authors as possible answers to the difficulty of finding a credible plan through which the saving God will reach all humankind.

The framework of exclusivism, inclusivism and pluralism reflects a spectrum of opinion on the question of salvation. The exclusivist (or particularist) school of thought maintains that salvation is obtained only through Jesus Christ who is the unique incarnation of God. A personal confession of faith in Christ and his substitutionary death is regarded as being necessary. Many questions arise from this view, one of the most pertinent being the final destiny of those who have not had the opportunity to hear of Jesus Christ. Inclusivists hold to the uniqueness of Jesus and acknowledge his person and work in procuring salvation for all humankind. However, this view argues that hearing about Jesus, and conscious faith in him, is not necessary. Therefore, inclusivists find efficacy in a "wider hope" for the unevangelised. As noted above, the pluralist school believes that there is moral and spiritual value in all religions. The idea that God has revealed himself in Jesus Christ is dismissed, and Christianity is judged to be one of many legitimate ways to the ultimate Reality. Traditional doctrines of the Christian church are dismantled in order to promulgate pluralism. 
It should be noted that the above are narrowly defined categories and no theologian fits neatly into any one paradigm. Important diversities within them will be apparent in many of the arguments that follow. Some theologians are frustrated by the three paradigms. For example, Terrance Tiessen has noted that the "usefulness of the classification is now frequently questioned," and attempted to construct his own categories. ${ }^{15}$ Netland has also stated his reservations: "I am increasingly unhappy with this taxonomy as it tends to obscure subtle, but significant, differences among positions and thinkers ... as the discussions become increasingly sophisticated and nuanced, it is often quite difficult to locate particular thinkers in terms of the three categories." ${ }^{, 16}$ Nevertheless, the device is useful for the purposes of this study since it helps to locate authors' views within a spectrum, and in relation to widely recognised categories.

The central chapters of the thesis examine and critique the ideas of Netland, Sanders and Pinnock respectively. Each of these theologians has written at least one substantial volume that directly addresses questions pertaining to religious pluralism from an evangelical perspective. ${ }^{17}$ The following chapters introduce each author, and analyse his stance on the basis of the relevant writings. The authors' particular views and assumptions are identified, as well as particular contributions which are made to

\footnotetext{
${ }^{15}$ Terrance L. Tiessen, Who Can Be Saved? Reassessing Salvation in Christ and World Religions (Downers Grove, IL.: InterVarsity Press, 2004), 31-32.

${ }^{16}$ Netland, Encountering Religious Pluralism: The Challenge to Christian Faith and Mission (Downers Grove, IL.: InterVarsity Press, 2001), 47.

${ }^{17}$ Netland, Encountering Religious Pluralism; John Sanders, No Other Name: An Investigation into the Destiny of the Unevangelised (Grand Rapids: Eerdmans, 1992); Clark H. Pinnock, A Wideness in God's Mercy: The Finality of Jesus Christ in a World of Religions (Grand Rapids: Zondervan Publishing House, 1992). Further relevant works by all three authors are noted in subsequent chapters.
} 
the broader debate. A final chapter recognises this sample of the great quantity of evangelical responses to the question of religious pluralism. It gives attention to evangelical theology and identity, and in particular, draws conclusions on evangelicalism's relevance to the twenty-first century.

The number of recent volumes addressing questions of religious pluralism is evidence of the issue's significance. The rapid spread of inclusive pluralistic ideas among evangelicals is also evident. While Netland, Sanders and Pinnock all reject some aspect, or aspects, of religious pluralism, there are signs of its influence. Exclusivist writers tend to be the most wary of these developments because of their potential to undermine orthodox views on the doctrine of God, and the person and work of Christ. As Netland notes, matters raised by religious pluralism are not inconsequential, nor are they the "latest theological fad" but are "here to stay ... touching every major area of theology." ${ }^{18}$ Netland considers that accommodation erodes Christian faith. Nevertheless, engagement with religious pluralism has yielded a range of responses. The incompatibility of some of these positions suggests both the importance of the topic, and its salience as a marker of divisions within the evangelical theological community.

These three theologians have each focused on areas of theology which they either see as needful to retain within evangelicalism, or recognise as doctrines which they believe are unhelpful in solving some of the theological problems of today, and therefore should be revisited. In the following chapters, discussion of the writers'

\footnotetext{
${ }^{18}$ Netland, Encountering Religious Pluralism, 14.
} 
viewpoints clarifies the theological matters on which they differ, and the extent to which their beliefs have reaffirmed, or have shifted from, the historical evangelical position. 


\section{Chapter Two}

\section{HAROLD A. NETLAND, EXCLUSIVIST}

Harold A. Netland is widely regarded as one of the foremost exponents of exclusivism, and has been a staunch defender of this position. In this chapter the restrictive nature of Netland's arguments for Christianity as the true religion will be examined. While he is unwilling to dismiss all non-Christian religions as being completely without value, his stance is that only Christianity offers salvation. Netland is aware that much of the world opposes his view, favouring instead more lenient approaches to other faiths. Nevertheless, he asserts that the foundation of Christian exclusivism is found in Scripture, not only in the New Testament but also in references to idolatrous practices which were denounced in the Old Testament. ${ }^{1}$ Before proceeding to explain the term "exclusivism" and to ascertain Netland's place in this evangelical grouping, it is necessary to acknowledge Netland's background and the influences which led to his rejection of both inclusivism and pluralism.

\section{Biographical}

Netland was nurtured in an atmosphere of traditional Christianity while surrounded by the Japanese world of multiple religions. This is evident from the Introduction to his most important work on the question of pluralism, Dissonant Voices. ${ }^{2}$ Netland's parents were evangelical missionaries with the Evangelical Alliance Mission

\footnotetext{
${ }^{1}$ Netland, Dissonant Voices, 10.

${ }^{2}$ Ibid., viii.
} 
(TEAM). ${ }^{3}$ The Mission's conservative theological emphases included the belief that the Bible was the inspired Word of God, being God's written revelation to humankind; that Jesus Christ was born into a sinful world to be the one and only Saviour of all humankind through his death and resurrection; that Jesus Christ is the incarnation of God, truly divine and truly human. The perceived need for the gospel to be preached to all adherents of other faiths was the reason for his parents being in Japan.

Born in Karuizawa, Japan, 1955, Netland lived primarily in Japan during his high school years but continued his education from 1973 to 1984 in California. He married Ruth Ford in Minnesota in 1981. Three years later, he and his wife moved to Japan to serve as educational missionaries with the Evangelical Free Church of America from February 1984 to June $1993 .{ }^{4}$ While in Japan, Netland was involved

\footnotetext{
${ }^{3}$ TEAM was founded in 1890 by Fredrik Franson, a young Swedish man who had initially settled with his parents in Nebraska, 1869. They had been members of the free, non-state church of Sweden. Fredrik later expressed his desire to train for church ministry which he did under D. L. Moody in Chicago. He returned for a time to Nebraska to work amongst Swedish immigrants, then to Utah where 30,000 Swedish immigrants had settled on inexpensive land. After hearing Hudson Taylor's challenge for missionaries to evangelise China, Fredrik formed six missionary sending agencies in European countries. All six agencies continue to send out missionaries to this day. Fredrik established a training class for work in cross-cultural missions in New York, 14 October, 1890. This date is recognised as the inauguration of TEAM. Currently, TEAM has 750 missionaries in forty three countries on six continents. See http://www.ministrywatch.com/profile/The Evangelical-AllianceMission.aspx (accessed 2 May, 2009).

${ }^{4}$ The Evangelical Free Church of America (EFCA) was founded in 1950. Two church bodies: the Evangelical Free Church of America (Swedish) and the Norwegian-Danish Evangelical Free Church Association merged to form the new body. Both churches had their roots in the revival movements of the late nineteenth century. EFCA is an association of 1500 autonomous churches, now in 50 countries, committed to fulfilling the Great Commission. See http://www.efca.org/about-efca/ourhistory (accessed 29 April, 2009). Theologically, there is no difference between TEAM and EFCA, except that the former lists the Sacraments (Water Baptism and the Lord's Supper), as well as the belief in ministering angels and the existence of Satan. It does not necessarily follow that EFCA denies these beliefs.
} 
in some church planting and worked with Japanese students through the Japanese InterVarsity movement (known as KGK). He taught at the Tokyo Christian University in basic theology, history of Western thought, comparative cultures and English conversation. Since 1993 he has been the Naomi Fausch Professor of Philosophy of Religion and Intercultural Studies at Trinity Evangelical Divinity School (TEDS) in Illinois. ${ }^{5}$

Dissonant Voices was written while in Japan as were a number of articles and chapters in books. ${ }^{6}$ Contrary to what some think, Netland explains that Dissonant Voices is not based on his $\mathrm{PhD}$ dissertation; that project was written under John Hick at Claremont, ${ }^{7}$ but addressed issues in the philosophy of language and theology. The book was partly a consequence of his time with Hick, but more particularly his subsequent ministry in Japan during which time it became clear to him that questions of the relation of Christian faith to other religions were unavoidable. "I felt that I

\footnotetext{
${ }^{5}$ TEDS is part of the Trinity International University operated by the Evangelical Free Church of America, accredited in 1973. The Divinity School Application Form states that "Trinity is a confessional school, and its faculty is committed to the historic creeds of the ancient church and to the major confessions of the Reformation period. Specifically, every faculty member signs the School's Statement of Faith and affirms his or her agreement with its articles." TEDS Statement of Faith accords with that of TEAM, except for TEAM's affirmation of (a) the belief in ministering angels, and (b) the existence of Satan and his opposition to the work of God. TEDS Standards of Conduct reveals a strict code of behaviour which demands teetotalism, morality in thought and action and a high degree of personal standards and conduct. See http://www.tiu.edu/sfe/pdfs/teds0506 app.pdf (accessed 30 April, 2009).

${ }^{6}$ See, for example, "Why Jesus Instead of Buddha? Christian Mission in a Religiously Plural World," in How Wide is God's Mercy? Christian Perspectives on Religious Pluralism, ed. Dale W. Little (Tokyo: Hayama Missionary Seminar $34^{\text {th }}$ Annual Report, 1993).

${ }^{7}$ Netland is careful to express his appreciation of Hick "as a person and as a scholar." Dissonant Voices, ix.
} 
needed to work through the issues," explains Netland, "so the book began as an article and then grew into a book in its own right.",

\section{Exclusivism}

Netland's exclusivist view emphasises that salvation is mediated exclusively through Christ and that there is no saving dimension in any other religion. These ideas, he argues, are based on the traditional doctrines of the Christian church. His encounter with non-Christian religions while in Japan was also crucial in formulating this position. Netland's knowledge and observation of what, to his mind, were the inadequacies of four religious traditions, namely, Hinduism, Buddhism, Islam and Shinto, led him to a detailed evaluation of each in terms of their truth claims.

Netland uses the term "truth claims" to define the fundamental affirmations and assertions operative within a particular religious tradition. The religious community accepts these beliefs which widen to the observance of rituals, behaviour patterns and expected outcomes for the community. However, for religions such as Hinduism and Buddhism, Netland explains, it is virtually impossible to define basic beliefs because of the many varieties in the sects and the unacceptability of some beliefs for the different members. ${ }^{9}$ Nevertheless, in Dissonant Voices, he addresses three important questions with respect to the major religions; that is, their view of the nature of the religious ultimate, the nature of the human predicament, and the nature of salvation (or alternatively enlightenment or liberation). These questions are not

\footnotetext{
${ }^{8}$ Netland, correspondence to C. Worsfold, 2 May, 2009.

${ }^{9}$ Netland, Dissonant Voices, 41.
} 
answered in the same way by the different religions. ${ }^{10}$ In other words, the problem of "conflicting truth claims" arises. While these inevitably and do exist, Netland argues that such differences effectively weaken the case for religious pluralism. ${ }^{11}$

Pluralists are often regarded as non-judgmental in accepting beliefs and practices of other faiths, but Netland disagrees that this is actually true. Rather, he emphasises the importance of the conflicting fundamental truth claims between Christianity and other religions. Pluralists, such as Paul Knitter, argue that this is not the case: there is one divine reality and this is central in the many religions; no tradition can claim definitive truth. ${ }^{12}$ This theocentric idea is put forward by other pluralist writers, too, including Wilfred Cantwell Smith, J. A. Robinson and R. Pannikar. ${ }^{13}$ Netland does not see this as accepting on the part of pluralists, for certain exclusivist Christian doctrines (the incarnation, for example) are viewed as incompatible with the other's tradition, and thus are rejected by such authors as false. ${ }^{14}$ The pluralist, R. Pannikar agrees with the theocentric idea but concedes that any claim to truth "has a certain built-in exclusivity. If a given statement is true, its contradictory cannot also be true. And if a certain human tradition claims to offer a universal context for truth, anything contrary to that 'universal truth' will have to be declared false." ${ }^{15}$ It

\footnotetext{
${ }^{10}$ Netland, Dissonant Voices, 36.

${ }^{11}$ Netland, Encountering Religious Pluralism, 188.

12 John H. Hick and Paul F. Knitter, eds, The Myth of Christian Uniqueness (Maryknoll, NY.: Orbis, 1987), 53.

${ }^{13}$ Netland, "Exclusivism, Tolerance and Truth," Missiology 15: 2 (April 1987): 250.

${ }^{14}$ Ibid., 251.

${ }^{15}$ Ibid., 250.
} 
appears, then, that Netland is justified in saying that pluralists do not accept, but rather contradict, certain Christian truth claims.

In a recent work, Netland explains that there is no single accepted definition of the term "exclusivism". Until the nineteenth and twentieth centuries when more open views of other religions were propagated by liberal Protestants and Vatican II, Netland claimed that the beliefs of the Christian church, both among Protestants and Roman Catholics, were that: “(a) The Bible comprises God's distinctive written revelation, and where the claims of Scripture are incompatible with those of other faiths, the latter are to be rejected; (b) Jesus Christ is the unique incarnation of God, fully God and fully man, and only through the person and work of Jesus Christ is there possibility of salvation; (c) God's saving grace is not mediated through the teachings, practices, or institutions of other religions." 16

The three categories of exclusivism, inclusivism, and pluralism, explains Netland, have been adopted relatively recently. "Exclusivism is often used for the view that only those who hear the gospel of Jesus Christ in this life and respond explicitly in faith to Christ can be saved. But many evangelicals reject this definition of exclusivism and recent discussions of soteriology have become sufficiently nuanced that trying to classify them in terms of just a few categories, is misleading." ${ }^{17} \mathrm{He}$ further points out that "defining the categories in terms of salvation makes it difficult

\footnotetext{
${ }^{16}$ Netland, "Religious Exclusivism," in Philosophy of Religion: Classic and Contemporary Issues, ed. Paul Copan and Chad Meister (Oxford: Blackwell Publishing, 2008), 68.

${ }^{17}$ Ibid., 69.
} 
to address other questions demanding attention." ${ }^{18}$ One might be an exclusivist in a particular area of belief while, at the same time, holding to an inclusivist view on another matter.

In the introduction to Dissonant Voices, Netland presents the work as a "kind of defense of Christian exclusivism" and follows with his definition in the first chapter:

Exclusivism maintains that the central claims of Christianity are true, and that where the claims of Christianity conflict with those of other religions the latter are to be rejected as false. Christian exclusivists also characteristically hold that God has revealed himself definitively in the Bible and that Jesus Christ is the unique incarnation of God, the only Lord and Saviour. Salvation is not found in the structures of other religious traditions. ${ }^{19}$

The above, for Netland, is evangelicalism in its exclusive form; traditional and orthodox Christianity. These ideas are set out as propositions later in Dissonant Voices, ${ }^{20}$ and reiterated in Encountering Religious Pluralism where Netland uses the categorisation of "Particularism.",21

Netland explains his use of the term "exclusivism" in Dissonant Voices. For, although he regarded the label of exclusivism as "unfortunate", he used the terminology at that time to avoid any confusion in the debate - in spite of the negativity directed toward the view as being arrogant and bigoted. Futhermore, he defended the terminology by referring to the Lausanne Covenant position from 1974,

\footnotetext{
${ }^{18}$ Netland, "Religious Exclusivism," 69.

${ }^{19}$ Netland, Dissonant Voices, 9.

${ }^{20}$ Ibid., 34.

${ }^{21}$ Netland, Encountering Religious Pluralism, 49.
} 
and the common use of the term at the time of writing. He argued that if Christian exclusivism was properly construed, it ought not attract negative connotations. ${ }^{22}$

Other authors have variously used the terms "particularism" and "restrictivism" in preference to exclusivism. ${ }^{23}$ Netland's more recent works finely tune his views on a theology of religions. In these, he expresses greater dissatisfaction with the three terms used in this thesis, noting that they are "too restrictive and distort the many varieties of perspectives offered." ${ }^{24} \mathrm{He}$ also observes that it is virtually impossible to sort into neat categories the range of evangelical answers to the question of salvation.

In Netland's view, exclusivism does not dismiss the notion that there is something of value to be learned from other faiths. He admits that there is disagreement among exclusivists on this point, and varied opinion about other religions. In the final analysis, though, exclusivists say that non-Christian religions "provide a false or inaccurate picture of reality and that salvation is not attained through the beliefs and practices of other religious traditions." 25 Clearly, there is the need for respect to be shown to other religious traditions and dignity afforded their adherents. At the same time, the notion is rejected that all are teaching the same truth, but in a different way; all roads do not lead to the top of the mountain for "one may lead over a precipice." This is illustrated by the fact that the three questions which Netland asks of major religions earlier in this chapter are given diverse treatment by various religions. He

\footnotetext{
${ }^{22}$ Netland, Dissonant Voices, 35.

23 Okholm and Phillips, "Introduction,” 19.

${ }^{24}$ Netland, correspondence to C. Worsfold, 2 May, 2009.

${ }^{25}$ Netland, Encountering Religious Pluralism, 49.
} 
rules out any semblance of a "power game" to which the search for truth can easily descend if one party desires to gain superiority over the other. For Netland, the most important question to be asked in view of the human predicament is the nature of salvation; and for him, exclusivism provides the answer.

Netland's observation that exclusivists' views vary considerably may be demonstrated with respect to differences concerning the matter of the relationship between a loving God and those who have never heard of his offered salvation. How does the exclusivist address the question of God's saving will for all humankind? Alongside that is the problem of millions who have died without hearing the Christian gospel and, therefore, have not had the opportunity to make any decision to accept Christ.

Netland notes that evangelicals are not in agreement on every points of belief, least of all on this matter of the eternal destination of those who have never heard or received the gospel. He sees the issue as remaining controversial and even becoming more divisive in the years ahead. His own view of this problem is not spelled out in Dissonant Voices, where he merely illustrates the many opinions held. In his later work, Encountering Religious Pluralism, he points out the importance of all evangelicals focusing on the ideas they share over this issue rather than on their disagreements. That is to say, all evangelicals believe: that humankind everywhere is in a sinful state; that Jesus Christ is the only Saviour; that salvation is offered and received because of God's grace and the faith in him that individuals express; and, that God is just in his dealings with those who have not accepted him. Netland appears to side-step the issue of the destiny of those who have never heard the 
gospel, and clearly takes a different view from Don Carson, an exclusivist colleague, who discusses and dismisses ideas put forward by the evangelicals who represent inclusivist thought, Sanders and Pinnock. ${ }^{26}$

In Encountering Religious Pluralism, Netland's thoughts on the destiny of those who have never heard the gospel message become clearer. He takes a moderate stance in that he does not deny the possibility of the knowledge of God revealed in general revelation being helpful in an individual's salvation. He sees that the former may elicit a response which could lead to faith for forgiveness. He is loath, however, to go further than what he believes the Scriptures allow, noting that the New Testament gospel stories tell of the Good News being heard before a response is made to God's grace, followed subsequently by saving faith. ${ }^{27}$

Some evangelical theologians who follow exclusivist thought in matters of the inerrancy and authority of the Scriptures, the sovereignty of God, and salvation through Jesus Christ, consider that there is a distinct possibility of general revelation contributing to, and perhaps leading to salvation. For example, J. I. Packer considers the notion that the explicit message of the gospel may not be necessary for salvation: "The answer seems to be, yes, it might be true.... If ever it is true, such worshippers will learn in heaven that they were saved by Christ's death and that their hearts were renewed by the Holy Spirit." But Packer cautions that there is no guarantee "that

\footnotetext{
${ }^{26}$ D. A. Carson, The Gagging of God: Christianity Confronts Pluralism (Grand Rapids: Zondervan, 1996), 285-300.

${ }^{27}$ Netland, Encountering Pluralism, 323.
} 
God will act thus in any single case where the gospel is not known or understood.,"28 Because the whole question underlines such serious implications, Netland urges humility in facing it, sorrow for those whose eternity will mean separation from God, and repentance over one's own lack of compassion which impedes the progress of preaching the gospel to all peoples. ${ }^{29}$

\section{Explaining the Drift from Exclusivism}

Netland does not concede that his exclusivism is merely a position taken on the relationship of Christianity to other faiths. Rather, he states that his stance is built on four propositional truths which he believes are Scripture-based. These beliefs, alluded to earlier in this chapter, are as follows: (a) Jesus Christ is the unique incarnation of God, fully God and fully man; (b) only through the person and work of Jesus Christ is there a possibility of salvation; (c) the Bible is God's unique revelation written, and thus is true and authoritative; and (d) where the claims of Scripture are incompatible with those of other faiths, the latter are to be rejected as false. $^{30}$

In Netland's opinion, a gradual departure from previously accepted Christian beliefs, and efforts to discredit the authority of Scripture assisted in exclusivism "falling on hard times." He states that in many quarters, exclusivism is regarded as "morally

\footnotetext{
${ }^{28}$ J. I. Packer, “'Good Pagans' and God's Kingdom,” Christianity Today (January 17, 1986): 25. Packer is a well-recognised theologian who is "unequivocally evangelical. Knowing God personally through the person and work of Jesus Christ is a hall mark of his labours." J. Mitchell Jr., "James Innell Packer," in Evangelical Dictionary, $2^{\text {nd }}$ ed., 881.

${ }^{29}$ Netland, Dissonant Voices, 277.

${ }^{30}$ Ibid., 34.
} 
questionable and out of touch with the realities of our pluralistic world."31 The opportunities to relate to adherents of other faiths which were previously little known, Netland suggests, helped to undermine the exclusivist point of view.

Netland places scepticism at the root of the challenges to important Christian doctrines pertaining to salvation. He notes that "the ideology of pluralism did not suddenly appear out of nowhere" and one important influence among others has been the deepening scepticism about the claims of orthodox Christianity. There is little doubt in Netland's mind that scepticism "has contributed to the erosion of confidence in the truth of the Christian faith." 32

Netland's analysis links the scepticism underlying "the ideology of pluralism" with postmodernity, arguing that the rise of postmodernity has intensified scepticism toward Christian belief and values. In this interpretation, postmodernity is primarily understood in terms of a sceptical attitude towards absolute authority, which increasingly affects trust in traditional doctrinal formulations. ${ }^{33}$ The "demise of exclusivism", he writes, is traceable to the same influence. ${ }^{34}$ Netland argues that, in the sceptical climate of postmodern culture, traditional Christianity became seen as irrelevant to personal values and thought, while the church' teachings were perceived as lacking credibility.

\footnotetext{
${ }^{31}$ Netland, Dissonant Voices, 33.

${ }^{32}$ Netland, Encountering Religious Pluralism, 15.

${ }^{33}$ Ibid., 125.

${ }^{34}$ Netland, Dissonant Voices, 28.
} 
Scepticism, however, has older antecedents. Netland accepts this, and notes its emergence in the modern world on several fronts, including, for example, the development of biblical criticism. He discusses Immanuel Kant (1724-1804) as one whose biblical criticism contributed significantly to the spread of scepticism. Kant downplayed any idea of the Bible as the revelation of God. Rather, it was a human record of history and could therefore be scrutinised and criticised as such. Kant allowed for a kind of rational faith on moral grounds but "explicitly rejected the scandal of particularity of orthodox Christianity, with its claims about special revelation and a particular incarnation.",35

Criticism of the New Testament, also in the late seventeenth and eighteenth centuries, gave rise to the suspicion that it was not possible to base a theological position on Scripture. Doubt was cast on the reliability of the gospels and efforts were made to discredit traditional Christian doctrines and pronounce them fraudulent. If this could be successfully accomplished the records of Jesus' life and ministry in the gospels would be disproved. ${ }^{36}$

This scepticism is prominent in pluralist thought, as found in the writings of Hick. Hick dismisses the idea that any authentic knowledge of Jesus can be gained from the New Testament. He believes that imagination has played a large part in constructing "pictures" of Jesus, and that it was the "cultural environment" of the

\footnotetext{
${ }^{35}$ Netland, Encountering Religious Pluralism, 139.

${ }^{36}$ An example is found in the writings of Hermann Samuel Reimarus (1694-1768), the German theologian and philosopher who sought to present Jesus as nothing more than a moral religious teacher and questioned the reliability of the gospels. See Alister McGrath, Christian Theology: An Introduction, $3^{\text {rd }}$ ed. (Oxford: Blackwell, 2001), 175.
} 
ancient world which deified Jesus. ${ }^{37}$ Hick views the New Testament documents as being mostly constructs of the early Christians, or that they recorded the beliefs of the early church but cannot now be relied upon to give an accurate record of what Jesus said and did. Netland repudiates these positions. ${ }^{38}$ He contends that the Bible is God's self-revelation; consequently, Christians are rightfully able to base their beliefs on Scripture. He also thinks that the ideas of other Christians should be measured against the outlines of Scripture-based truths. Pluralists in turn reject this position and call into question early church formulations of doctrine, arguing that the incarnation of a divine Saviour, for example, was required merely to deal with early beliefs of sin, the fall and redemption.

\section{Cornerstone Exclusivist Doctrines}

The following three traditional Christian doctrines are particularly important to exclusivists. For Netland, they comprise the cornerstone of biblical truth. He believes that these truths can in no way be denied or tampered with, for that would lead to an inadequate understanding of salvation which is available to all human beings, even if they are effective only for those who believe.

\section{(1) The Incarnation}

Of all the traditional theological ideas that Netland considers are threatened by religious pluralism, the doctrine of the incarnation is arguably the most central. Importantly, the erosion of this orthodox Christian doctrine arose from the post-

\footnotetext{
${ }^{37}$ Netland, Dissonant Voices, 244.

${ }^{38}$ Ibid., 245.
} 
Enlightenment scepticism already discussed. The exclusivist notion of Jesus of Nazareth being the incarnation of God became highly contentious. Hick argues that a literal incarnation could be formulated in ways to fit better with modern thought, as well as with other cultures. ${ }^{39}$ In any case, the incarnation is not clearly spelled out in Scripture. He regards the incarnation as myth, albeit a profound myth; it is "an image or idea which is applied to something or someone but which does not literally apply, but which invites a particular attitude in its hearers. ${ }^{" 40}$ Hick concedes that Jesus was "intensely and overwhelmingly conscious of the presence of God ... his life vibrated, as it were, to the divine life; and as a result his hands could heal the sick, and the poor in spirit were kindled to new life in his presence."41 In other words, the incarnation should be understood in a mythological or metaphorical sense as holding that God was present and active in Jesus in a manner similar to the ways in which God is present in other religious leaders. ${ }^{42}$

Netland points out that if Hick were to subscribe to the traditional view of the incarnation, he would find it difficult to reconcile other religious traditions with Jesus, the New Testament and the Christian faith. Hick would be in the position of having to revise his ideas surrounding other ways to obtain salvation. ${ }^{43}$ However, Hick does not subscribe to the literal view of God incarnate. His problem is that if it

\footnotetext{
${ }^{39}$ Netland, Encountering Religious Pluralism, 174.

${ }^{40}$ John Hick, "Jesus and the World Religions," in The Myth of God Incarnate, ed. John Hick (London: SCM, 1977), 178.

${ }^{41}$ Ibid., 172.

${ }^{42}$ Ibid., 178.

${ }^{43}$ Netland, Encountering Religious Pluralism, 171-172.
} 
were true, only the Christian faith would provide "a doorway to eternal life." The result of such thinking implies that "the large majority of the human race so far have not been saved." 44

Netland claims that the doctrine of Jesus Christ as the unique incarnation of God, fully human and fully God, has been the dominant view of Christ in the creeds of the Christian faith since the fourth century. The doctrine cannot be dispensed with because from it other doctrines flow, such as the deity of Jesus, the efficacy of the cross, the resurrection and the uniqueness of Jesus. It is thus crucial to exclusivist thought. But Netland is also aware that "profound mystery" surrounds it, and that it presents a problem for other religions that may be willing to acknowledge Jesus as an historical figure, and a moral and great teacher, but cannot accept the notion of Jesus being God incarnate. The latter is not seen as a truth which is intelligible and therefore is not to be regarded as secure for all time. For the pluralist, Jesus is one Christ among others. Netland believes that the exclusivist stance is firmly rooted in traditional Christian doctrine, therefore, the latter is to be upheld. He notes that I. Howard Marshall concurs, as in Christ the Lord, where he writes:

We have found that the concept of incarnation i.e. that Jesus Christ is the Son of God made flesh, is the principle of Christological explanation in the writings of John, the writings of Paul including the Pastoral Epistles, the Epistle to the Hebrews, and $1^{\text {st }}$ Peter. The view that it is found merely on the fringe of the New Testament is a complete travesty of the facts. ${ }^{45}$

\footnotetext{
${ }^{44}$ Hick, "Jesus and the World Religions," 180.

45 I. Howard Marshall, "Incarnational Christology in the New Testament," in Christ the Lord: Studies in Christology Presented to Donald Guthrie, ed. Harold H. Rowdon (Leicester: InterVarsity Press, 1982), 13.
} 
Netland maintains that theological scepticism regarding the incarnation results in a defective Christology. ${ }^{46}$ It is precisely because he is recognised as the incarnate Word of God, Netland argues, that the truth of Christ's words are also recognised. If the Scriptures which Netland lists in Marshall's reference are discounted, regarded as metaphorical, or become an option, then he believes that the whole range of traditional Christian doctrine becomes inessential. However, Netland holds to the belief that the incarnation is an essential characteristic of Christianity, distinguishing it from other religions and, in that sense, becoming offensive to a pluralistic world. In exclusivist thought God became human to bear upon himself the sins of the world by way of the cross, seen as God's love clearly displayed, which leads to what Netland identifies as a second key exclusivist doctrine.

\section{(2) The Centrality of the Cross}

Netland is adamant that the Cross of Christ is the only avenue open for individuals to be reconciled to God, although precisely how Jesus' death mediates forgiveness for sin is difficult to define unless one looks to the typology of the Old Testament. This foreshadows Paul's declaration of atonement in his letter to the Corinthians where Christ is depicted as the offering for $\sin ,{ }^{47}$ brought about by an act of God in which Christ became the substitute for sinners. Arguments against this conviction mean that there is no Good News to preach. "The cross," writes McGrath, "is seen as the centre of all Christian thought, in that from its centre radiate Christian statements on ethics, anthropology, the Christian life and so on. The doctrines of revelation and

\footnotetext{
${ }^{46}$ Netland, Dissonant Voices, 261.

${ }^{47} 2$ Cor 5:21.
} 
salvation, so easily detached from one another, converge on the cross." ${ }^{\text {"48 }}$ It is true that the early orthodox view depicted an offended and angry God who demanded appeasement for the sins of humankind against him, and that only the cross could bring about a placation. "The greatest merit [of this notion] was the serious view it took of sin," comments James Stewart, "its greatest defect was its disastrous view of God. ${ }^{49}$ Scripture does not support the primitive idea deplored by Stewart. Therefore, Netland sees in Scripture the view taken by exclusivists, that Christ became the substitute for humankind and paid the price of sin, and that the initiative was taken by a gracious and merciful God. In this way, and this way only, Netland argues, humankind is reconciled to God. ${ }^{50}$

It cannot be said that similar weight to the importance of the cross is given by nonexclusivist thinkers. Rather there is a departure from the fourth of Bebbington's evangelical distinctives, crucicentrism, listed in Chapter One of this thesis. For example, the inclusivist, John Sanders, writes in The God Who Risks, "Although Scripture attests that the incarnation was planned from the creation of the world, this is not so with the cross. The path of the cross comes about only through God's interaction with humans in history. Until this moment in history other routes were, perhaps, open ... Though the incarnation ... may have been in God's plan all along,

\footnotetext{
${ }^{48}$ Alister E. McGrath, A Passion for Truth: the Intellectual Coherence of Evangelicalism (Leicester: Apollos, 1996), 41.

${ }^{49}$ James S. Stewart, A Man in Christ: The Vital Elements of St. Paul's Religion (London: Hodder and Stoughton, 1964), 216.

${ }^{50}$ Netland, Encountering Pluralism, 319.
} 
the cross as the specific means of death may not have been." ${ }^{, 51}$ This interpretation ignores, in Netland's opinion, the record of Scripture. Netland, with all exclusivists, sees God's plan of salvation as involving Christ's sacrificial death on the cross, which is to say that the acceptance of the cross by Jesus was because of the will and purpose of God. This, of necessity, must be downplayed by inclusivists because the idea of Jesus' death being planned from eternity, and offered as a substitute for sinners, impinges on inclusivism's important points of view regarding freedom of will and the nature of $\sin ^{52}$

In No Other Name, Sanders devotes a portion of one chapter to five basic theological considerations in support of inclusivism. ${ }^{53}$ This chapter does not address the significance of the cross and Jesus' subsequent rising from the tomb, in the apostle Paul's terms, as the scene of God's supreme demonstration of his love for sinful humankind. The omission is consistent with the inclusivist emphasis that God's love and forgiveness are effective through other religions, so that knowledge of Jesus and the cross are not necessary for salvation.

Hick's pluralist view gives less credence to the cross and atonement. There is no theory required, he suggests, about forgiveness of sins through Jesus' death on the cross, neither was this historical event in any sense an atoning sacrifice. In support of his point, Hick quotes the Lord's Prayer where no mention of a sacrifice is made,

\footnotetext{
${ }^{51}$ John Sanders, The God Who Risks: A Theology of Divine Providence, $2^{\text {nd }}$ ed. (Downers Grove, IL.: InterVarsity Press, 2007), 102.

${ }^{52}$ Ibid., 106.

${ }^{53}$ John Sanders, No Other Name: An Investigation into the Destiny of the Unevangelised (Grand Rapids: Eerdmans, 1992), 224-249.
} 
and the prodigal son (Luke 15:11-32) who was received and forgiven at once. It is thus possible for Hick to avoid denying any other spiritual leader who inspires and models the life of a citizen in God's kingdom for another religious tradition. ${ }^{54}$

For Paul, the cross was where forgivenesss was offered, and humankind's reconciliation to God was made possible. The controversial but influential Catholic theologian, Hans Kung, supports this view of the centrality of the cross in Pauline theology when he writes:

For the Apostle Paul, regarding himself as chosen to preach the Gospel among the Gentiles, the Christian message is essentially the message of the Crucified ... to put it briefly and epigrammatically, the Christian message is the word of the cross. It is a word which may not be cancelled or emptied of meaning, nor may it be suppressed or mythicized.... This crucified and living Jesus then is for believers the foundation which is already laid and which cannot be replaced by any other... He is indeed the centre and norm for what is Christian. ${ }^{55}$

The exclusivist position is in accord with the above quote, and argues that an inadequate treatment of the doctrine of the cross puts some strain on a theology of atonement. For, as Donald Baillie once noted, "God was uniquely present in the passion and death of Jesus, making Atonement, reconciling the world unto Himself." ${ }^{56}$ Netland points to atonement as taught in the New Testament, and rightly observes that it is "one of the great mysteries in Scripture." ${ }^{57}$ He maintains that the atoning sacrifice on the cross was a once only act of God, completed in its purpose

\footnotetext{
${ }^{54}$ Hick, "A Pluralist View," 58-59.

${ }^{55}$ Hans Kung, On Being Christian (Glasgow: William Collins Sons \& Co Ltd, 1974), 399-400.

${ }^{56}$ D. M. Baillie, God Was in Christ (London: Faber \& Faber, 1956), 191.

${ }^{57}$ Netland, Encountering Religious Pluralism, 319.
} 
and to which nothing can be added. The express purpose of the incarnation, told in the New Testament, was that Jesus came into the world to offer his life as a sacrifice, in order that humankind would not suffer eternal separation from God. ${ }^{58}$

\section{(3) The Authority of the Scriptures ${ }^{59}$}

Third in exclusivism's cornerstone of biblical truth is the recognition of divine authority of the Scriptures. This is central to exclusivist thought together with God's revelation to the world through the incarnation, and the cross of Christ. The scepticism directed towards these doctrines, and abhorrence of exclusivism have contributed, as Netland sees it, to the rise of religious pluralism. The authority of the Scriptures was never doubted by the early Christians because as Biblical scholar, F. F. Bruce explains, the authority of the Old Testament Scriptures was "ratified by the teaching and example of the Lord and his apostles. The teaching and example of the Lord and his apostles, whether conveyed by word of mouth or in writing, had axiomatic authority for them."60 Netland holds to the belief that the Bible is the revelation of God to humankind, written by human writers inspired by the Holy Spirit. He sees the might and sovereignty of God, the sinful state of humankind and God's redemptive plan culminating in the birth, life, death and resurrection of Jesus, and the forming of Christ's body, the church on earth, portrayed in the Scriptures.

\footnotetext{
${ }^{58}$ Mark 10:45; 1 John 3:5.

${ }^{59}$ N. T. Wright, The Last Word: Beyond the Bible Wars to a New Understanding of the Authority of Scripture (N.Y.: HarperCollins, 2005), 23-34. This is a "familiar phrase" Wright points out, but is enveloped in a larger divine authority. He suggests that a starting point is to accept the term "authority of Scripture" as shorthand for "God's authority exercised through Scripture."

${ }^{60}$ F. F. Bruce, The Canon of Scripture (Glasgow: Chapterhouse, 1988), 255.
} 
Evangelical opinions vary, for some say that a form of dictation was used by God, with words being chosen for the authors. Others believe that the personality and background of an individual author is clearly apparent, but that the influence of the Holy Spirit caused them to produce the infallible truth of God's mind and will for the world. Be that as it may, exclusivist evangelicals would not generally dismiss the human element. It is not the purpose of this discussion to explore the archaeological explanations of historical records in the Old Testament, nor the geographical questions raised in the New Testament stories. Suffice it to say that exclusivists believe the Bible to be the final authority and God's self-revelation to humankind. From the Scriptures they derive their conservative stance on three principles, discussed below, which Netland maintains were upheld by traditional Christianity until the mid-1900s. ${ }^{61}$ The first of these claims is that Scripture is divinely authoritative and must of necessity begin with God, for exclusivists admit to no authority outside of God. "If the claims of Scripture are incompatible with those of other faiths, the latter are to be rejected. ${ }^{, 62}$ Furthermore, the self-revealing God can be known only by revelation, through the guidance of the Holy Spirit as recorded in the original writings. The authority of the Old Testament is carried through to the New, shown by Christ's treatment of the Old Testament texts concerning himself and the work he came to do, thus fulfilling the prophecies. New Testament writers refer to Christ and the Good News as the word of God. Exclusivists like Netland thus declare their recognition of the authority of Scripture as borne out by Statements of

\footnotetext{
${ }^{61}$ Netland, Encountering Religious Pluralism, 48.

62 Ibid.
} 
Faith of TEAM, EFCA and TEDS. The inerrancy of the Scriptures is attested to, but with the qualifying phrase "without error in the original writings."

The third quality of evangelicals as given in Chapter One of this thesis concerns commitment to the Bible; evangelicals believed that all spiritual truth was to be found therein. ${ }^{63}$ Agreement on this point, states Bebbington, was characteristic among "all generations" of evangelicals, and up to the early nineteenth century, no debate on theories of infallibility or inerrancy of the Bible had surfaced. However, by the mid-nineteenth century, evangelical opinion was insisting on inerrancy, verbal inspiration and literal interpretation. The evangelical world divided, which led to "something approaching schism in their ranks." ${ }^{64}$ Immediately prior to the start of the twentieth century, a Bible League was formed for the express purpose of resisting attacks made on the "Inspiration, Infallibility and Sole Sufficiency" of the Scriptures as the Word of God. ${ }^{65}$ Bebbington's history details the crises in evangelicalism that followed, and records that the central issue concerned the infallibility of Scripture. When the InterVarsity Fellowship was established in 1928, the first clause of its basis of faith affirmed "the infallibility of Holy Scripture as originally given." 66

The relationship between the terms "infallible" and "inerrant" have been much debated; it has been an important consideration in evangelical theology, and of

\footnotetext{
${ }^{63}$ Bebbington, Evangelicalism in Modern Britain, 3.

${ }^{64}$ Ibid., 14.

${ }^{65}$ Ibid., 187, citing The Record (25 June 1909): 673.

${ }^{66}$ Ibid., 259.
} 
considerable relevance to the debate about pluralism. According to P. D. Feinberg, the two are essentially synonymous. Defining "inerrancy" Feinberg writes, "When all the facts become known, they will demonstrate that in its original autographs and correctly interpreted [Scripture] is entirely true and never false in all it affirms, whether that relates to doctrine or ethics or to the social, physical and life sciences." ${ }^{67}$ Feinberg's conclusion is that to deny the authority of the original text is to undermine the authority of the Bible the Christian has today.

The Chicago Statement on Biblical Inerrancy produced similar material in 1978, and was adopted by the Evangelical Theological Society (ETS) membership in 2005. The issue arose in 2003 when Sanders and Pinnock, members of the ETS, were propounding the "openness of God" position which, in the opinion of that Society, undermined biblical inerrancy.

In Netland's chapter, "Toward an Evangelical Theology of Religions” he lists among other biblical themes the written Scriptures which are "the definitive revelation for us. ${ }^{, 68} \mathrm{He}$ discusses the general revelation of God which can be discerned in nature pointing to the eternal Creator, and the human conscience which is the possession of every man, woman and child. "Special revelation" normally refers to the Scriptures, because the revelation of God took "definitive shape in the incarnation of Jesus" and for Netland, understanding this event rests upon the record of Scripture.

\footnotetext{
${ }^{67}$ P. D. Feinberg, "Inerrancy and Infallibility of the Bible," in Evangelical Dictionary, $2^{\text {nd }}$ ed., 156159.

${ }^{68}$ Netland, Encountering Religious Pluralism, 316.
} 
Netland believes it is the word of truth and he sees no reason to depart from the traditional Christian view held by exclusivists. "Christian exclusivists," he writes, "characteristically hold that God has revealed himself definitively in the Bible." 69 His defence of the foregoing doctrines is based on his view of the authority of Scripture. If this record is deemed to be unreliable, Netland sees difficulties arising in the doctrines of orthodox Christianity.

\section{Further Issues at Stake}

It has already been noted that religious pluralism is not a new phenomenon. In the last fifty years, evangelicals have not written widely on the subject, except to discuss matters relating to the destiny of the unevangelised. However, Netland notes that should this matter be settled, there remain other doctrines which are also important to discussions surrounding religious pluralism. Late in the twentieth century the World Evangelical Fellowship called theologians from nearly thirty countries to confer on the relationship between Christianity and other religions. The consensus was that a more adequate theology of religions was needed. In 2001 Netland took up this challenge and suggested that two conditions must be met: (1) that an evangelical theology of religions must be based on the Bible and, (2) that it must be faithful to beliefs of the Christian church as held through the centuries. ${ }^{70}$ With this in mind the following issues are considered:

\footnotetext{
${ }^{69}$ Netland, Dissonant Voices, 9.

${ }^{70}$ Netland, Encountering Religious Pluralism, 313.
} 


\section{(1) The Uniqueness of Jesus}

Referring to his concerns regarding scepticism, Netland explains that the Christian doctrine of the uniqueness of Jesus is questioned. This central truth claim is that God was definitively, uniquely, in the Jesus who lived his life in Palestine and was crucified, and raised to be "both Lord and Messiah.",71 Netland affirms that Jesus was, and is, uniquely significant; that he was not only sent by God, but was God, or in other words, God incarnate as formulated in John's gospel. ${ }^{72}$ To some, it is an inconceivably narrow view but for Netland, the uniqueness of Christ is not about bigotry, it is about truth. In his opinion, Scripture allows for no other means of salvation than that which comes through the person of Jesus Christ. Inevitably, this is a doctrine which evokes opposition, an example of which is expressed in a comment of Mark Thompson: "It is scandalous in the current climate to claim that Jesus of Nazareth is the unique revealer of the living God."73

The term "unique" has come under scrutiny as to its usefulness in correctly conveying the intended theological meaning. Discussion ranges from "a degree of impatience with the word" to "the abundant sloppiness in the use of the term, especially in theological writing." considers many alternatives and their implications, but returns to what he has found

\footnotetext{
${ }^{71}$ Acts 2:36.

${ }^{72}$ John 1:1-18.

${ }^{73}$ Mark D. Thompson, "The Uniqueness of Christ as the Revealer of God," in Christ the One and Only: a Global Affirmation of the Uniqueness of Jesus Christ, Sung Wook Chung, ed. (Grand Rapids: Baker Academic, 2005), 90.

${ }^{74}$ Bob Robinson, "What Exactly is Meant by the 'Uniqueness of Christ'? Part One," Evangelical Review of Theology 25 (October 2001): 362-365.
} 
to be "the best available." Robinson maintains that Christ is "absolutely different in every possible respect", "is not defined by anything else", "has an absolute and universal significance." Therefore, he argues, the concept of uniqueness is "worth defending and using., ${ }^{, 75}$

Robinson's comprehensive study accords with Netland's argument for the uniqueness of Jesus, which is derived from the New Testament assertions about him. While Netland deplores disparagement directed at the religious figures of other faiths, he contends for the statements made about Jesus Christ in the Scriptures, and the claims that Jesus made about himself. Netland's stance is that no other religious leader, although revered by his followers, can "claim to be universally normative for all peoples in all cultures." 76 The point is also made that the Christian doctrines of salvation and the uniqueness of Jesus, the Saviour of the world, need to be seen against the background of a sinful world. ${ }^{77}$ Netland emphasises that the basic problem of suffering and evil, which is spread through all humanity, stems from the sin of rebellion against God. Humankind is unable to remedy the resultant separation from God, and God's wrath and condemnation rest on the human race. ${ }^{78}$ Netland

\footnotetext{
${ }^{75}$ Robinson, "What Exactly is Meant by the 'Uniqueness of Christ'? Part Two," 86.

${ }^{76}$ Netland, Dissonant Voices, 260.

${ }^{77}$ Netland, Encountering Religious Pluralism, 318.

${ }^{78}$ Modern usage has corrupted the biblical meaning of "wrath". Rather than a sudden outburst of anger, God's wrath is a settled, controlled opposition to all evil. God has resolved to show the world that he is ready to forgive and that he has made provision for reconciliation with him through the life, death and resurrection of Jesus Christ. cf. John Stott, The Cross of Christ, $20^{\text {th }}$ Anniversary ed. (Nottingham: InterVarsity Press, 2006), 124, 202.
} 
sees the uniqueness of Jesus deriving from "the one-time event in which the eternal Creator who became man and took upon himself the sins of the world.",79

\section{(2) Propositional Truth}

Netland rejects the opinions of theologians who say, in various ways, that God does not reveal truths or propositions about himself but, rather, God reveals himself. Exclusivism's dependence on notions of faith and truth, they say, is "inadequate and misleading" in the field of religion. ${ }^{80}$ Propositional truth must contribute to a clear understanding of religious faith and belief. Netland is particular about his meaning of "proposition" and explains that, in his view, "statements" and "propositions" are virtually synonymous. The meaning expressed in a declarative sentence can be either implicitly or explicitly asserted. "In the logically basic sense," he writes, "truth is a quality or property of propositions. That is, a proposition is true only if the state of affairs to which it refers, is as the proposition asserts it to be; otherwise it is false. All propositions are either true or false and, strictly speaking, only propositions are either true or false. Propositions can thus be thought of as the minimal vehicle of truth." ${ }^{\prime 1}$

Netland takes issue with the Canadian theologian and professor of comparative religion, Wilfred Cantwell Smith, who opposed the idea of propositional truth and de-emphasised beliefs and doctrines in favour of the "inner subjective faith of persons." ${ }^{, 2}$ For Netland, this attitude to personal truth would lead to the embracing

\footnotetext{
${ }^{79}$ Netland, Encountering Religious Pluralism, 319.

${ }^{80}$ Netland, Dissonant Voices, 115.

${ }^{81}$ Ibid., 114-115.

${ }^{82}$ Netland, Encountering Religious Pluralism, 199.
} 
of pluralistic ideas and dispensing with a traditional Christian viewpoint on matters of belief. These would include the authority of Scripture which would be challenged if the inner faith of the believer were to take precedence over the revelation of God as written in the Bible. Christian doctrines could not be defined as true except to individuals who allowed these doctrines to direct their way of living. All traditions would be true for their adherents. For Netland, the above viewpoint is not a valid alternative to interpreting religious truth as propositional truth. ${ }^{83}$ Smith accepts that propositional truth is proper and, in fact, necessary in certain other fields, but inappropriate in the context of religion. Personal truth is dynamic, however, which means that any religious proposition or tradition might be true (or become true) for one individual, but not for another.

The argument against propositional truth is taken up by sceptical theologians and philosophers who question cognitive knowledge of God. This idea cuts across Christian tradition, which allows that God reveals information about himself through true propositions and the human ability, given by God, to receive that information. In Netland's view it is entirely possible for knowledge about God to be gained by humankind. He disagrees with those who say that "either one has propositional truth about God, or one has an existential encounter with God, but not both." 84 On the contrary, Netland argues that some knowledge of God is of primary importance if the individual is to respond appropriately to God. The ontological necessity of Christ for salvation is maintained independently of an epistemological understanding of Christ;

\footnotetext{
${ }^{83}$ Netland, Encountering Religious Pluralism, 198.

${ }^{84}$ Ibid., 201.
} 
both, for Netland and other evangelical exclusivists, are essential for salvation. ${ }^{85}$ Netland is convinced that the rejection of propositional truth is assisted by the idea of a non-propositional view of divine revelation: "If revelation is informative about God, then it must be capable of being expressed propositionally." 86

It is reasonable to expect that evangelicals would support the authority of the Scriptures and Christian tradition, though some inclusive evangelicals add culture to tradition and Scripture as a third source for theology. ${ }^{87}$ In Netland's exclusivist thought, Scriptural truth is not to be set aside for culture. He concedes that culture and religious issues are closely connected which leads to questions about relating the Christian faith to indigenous religious beliefs and practices. ${ }^{88}$ However, he contends that one particular religious figure and one religious perspective can be universally valid and normative for all peoples in all cultures, and is not surprised that this latter idea is dismissed by a pluralistic world as "morally and intellectually untenable." 89

\section{(3) Relativity}

Netland comments that the contemporary theological climate is accommodating and relativistic. Relativism tends to dismiss any claim that Christianity is uniquely true;

\footnotetext{
${ }^{85}$ The epistemological basis concedes that one must know about Christ and have some understanding of God's plan of redemption, while ontologically, the truth of the cross and resurrection must be accepted. All evangelicals do not agree with this exclusive stand, and pluralists believe individuals can be redeemed without necessarily knowing or ever hearing about Jesus Christ.

${ }^{86}$ Netland, Dissonant Voices, 126.

${ }^{87}$ An example being Stanley J. Grenz, Revisioning Evangelical Theology: A Fresh Agenda for the $21^{\text {st }}$ Century (Downers Grove: IL.: InterVarsity Press, 1993), 71-72.

${ }^{88}$ Netland, Encountering Religious Pluralism, 329.

${ }^{89}$ Ibid., 156.
} 
neither does it accept that salvation is available only through the Christ of the Gospels or that Christianity is valid for all time and for all cultures. Rather, it opens the door to uncritical evaluation of the beliefs of others. "[Religious] pluralism thrives," Netland asserts, "within a relativistic ethos that rejects traditional Christianity as untenable but is open to new religious alternatives." 90

The idea of relativism is discussed at length in Netland's works, where he observes that its influence on contemporary society is enormous. ${ }^{91}$ Netland distinguishes various types. He writes of "descriptive" relativism, that is, the recognition of diversity between people and cultures. Beyond that, "normative" relativism argues that what is morally right or wrong depends on the views of the culture in question. ${ }^{92}$ Of more concern to Netland is "cognitive" relativism, meaning that truth, knowledge and norms are relative to particular contexts. In fact, there is "no truth, knowledge or norms independent of particular contexts. ${ }^{, 93}$ Exclusivism, that is, a strict adherence to traditional Christian doctrines, has become unpopular while relativism is gaining influence. This is due to the promoting of tolerance of all other religions and an air of incredulity that religious truth can be viewed as unchanging. Cultural and religious diversity cannot be denied, therefore Netland poses the question as to whether human kind can rise above the many effects of particular "contexts and apprehend truths that

\footnotetext{
${ }^{90}$ Netland, Encountering Religious Pluralism, 129.

${ }^{91}$ Netland, Dissonant Voices, 166; for a full discussion on Relativism, see 166-180.

${ }^{92}$ Ibid., 169.

93 Ibid.
} 
... are independent of all such contexts?"94 If this is not possible, then relativism is inevitable.

Relative truth means that it differs according to place, person and time. If this is so, there can be no universal truth. The consequence, Netland believes, is that divinely revealed absolutes are questioned, while cultural conditioning becomes a more crucial factor. This idea means that commitment to the God of the Bible loses ground as a valid universal truth, and a more humanistic worldview develops.

\section{Summary}

This chapter has looked at the views of Harold Netland, which have been discussed as a model of a particular exclusivist stance. According to Netland, this position is founded on traditional orthodox Christianity; variance in evangelical opinion is primarily interpreted in terms of the effects that secularisation on the Christian doctrines of the church. In presenting his case for exclusivism, Netland draws upon his experience of many years living and working in the pluralistic religious world of Japan. He sets out to show what is not good about diversity which, he suggests, "is itself an effect of the Fall and sin." $" 95$ The call for pluralism to be embraced is based on a desire to find a way to deal with such diversity. Netland recognises the call to tolerance and to refrain from negative judgments of other religions, stems from genuine concern over violence and abuse among the religions, Christianity included. He wholeheartedly agrees that the Christian church ought to uphold truth and justice,

\footnotetext{
${ }^{94}$ Netland, Encountering Religious Pluralism, 290.

95 Ibid., 345.
} 
supporting the rights of others to follow religions of their choice. At the same time, he believes that the church's mission is to encourage religious others to be reconciled to God through Jesus Christ as Saviour and Lord. $^{96}$

Netland has found that some evangelicals have difficulty resisting the contemporary viewpoint, which he argues veers away from affirming the sovereignty of Jesus Christ. His adherence to traditional Christian doctrines epitomises exclusivity which does not give way on what he considers to be matters of faithfulness to Scripture. He is aware of secularism's influence and looks for an agreement among evangelicals on the meaning of the gospel and the authority of Scripture. However, Netland rejects any notion of dispensing with the Christian doctrines discussed in this chapter in order for that agreement to come about. He maintains that historical theology does not make room for non-Christian ideas as ways of salvation, but sees other religions as "human rebellion against God" rather than being a reasonable response to God. ${ }^{97}$

Netland's analysis does not exhaustively address the last fifty or sixty years' important discussion among evangelicals on the destiny of the unevangelised. One reason for this can be detected in his comment regarding religious pluralism and theological debates which, in his view, have not focused on the issues of pluralism to any great extent apart from one or two exceptions. Rather, Netland notes,

\footnotetext{
96 Netland, Encountering Religious Pluralism, 347.

${ }^{97}$ Ibid., 345.
} 
theologians addressing this subject "usually focus upon the destiny of the unevangelised, as if a clear answer on this matter resolves all remaining problems."98

This is not satisfactory to Netland, and while he fully supports the evangelical insistence on evangelism in Christian mission, Netland highlights other important dimensions of the church's mission in matters of social, economic and political deprivations in the world. ${ }^{99}$ Yet, for Netland, the last mentioned issues do not negate his perception of evangelicalism's need to retain its historic adherence to orthodox Christian doctrines. He argues that no saving dimension is found outside of Christianity, while on the other hand, he is not willing to close the door on the possibility of salvation for some who have not heard the gospel. If any are saved in this way, which is by no means certain in Netland's view, they have turned in faith to God because of what they have learned through general revelation. He maintains that the biblical method is to first hear the gospel, and then respond in faith to God's grace. ${ }^{100}$ It is clear from these observations that the stipulations Netland laid down in 2001 regarding the evangelical theology of religions, remain his guiding principles in his pursuit of exclusivist evangelicalism. ${ }^{101}$

\footnotetext{
${ }^{98}$ Netland, Encountering Religious Pluralism, 308.

${ }^{99}$ Netland, Dissonant Voices, 278.

${ }^{100}$ Netland, Encountering Religious Pluralism, 323.

${ }^{101}$ Ibid., 313-323.
} 


\section{Chapter Three}

\section{JOHN E. SANDERS, INCLUSIVIST}

Evangelicals do not agree on any single definition of "inclusivism" but the term generally refers to a diverse group of theological positions that support the possibility of general revelation enabling the unevangelised to appropriate God's saving grace. In common with all evangelicals, inclusivists agree on the love of God for humanity and the redemptive purpose of God. However, differences arise with other evangelicals when inclusivists claim that the saving God is revealed in other religions. The centrality of Jesus Christ in the plan of salvation is not disputed, but it is argued that individuals need not have explicit knowledge of Jesus, nor make a confession of faith in him, in order to gain salvation. Inclusivists are generally critical of stances like Netland's, which they consider give insufficient weight to the universal saving will of God. The question then focuses on the eternal destiny of those who have not been reached by the gospel, usually termed "the unevangelised." It is precisely this matter which led John Sanders to adopt his inclusivist position.

\section{Biographical}

John Ernest Sanders was born in Illinois, in 1956. His parents were not committed church attenders, but, infrequently, Sanders' mother would attend the First United Methodist church in Hoopeston, Illinois, taking the family with her. The Sanders home did not practise religious teaching for the children, neither were any prayers or religious rites part of family life. While in his sixth grade, Sanders attended weekly classes at the Methodist church, becoming confirmed as a member, although 
somewhat unenthusiastic. Towards the end of the twelfth grade, Sanders states that he became serious about Christianity. He left the Methodist Church and attended a fundamentalist Baptist community. A profound effect on Sanders' life came about through the evangelical Christian student association which he joined during his first year at college. He has remained among evangelical Christian communities since that time. ${ }^{1}$

Sanders' academic education commenced at Trinity College, Hartford, Connecticut, where he graduated with a B.A. qualification in 1979. He continued at Wartburg Theological Seminary of the Evangelical Lutheran Church in America, Iowa, achieving a Masters' degree. Sanders' doctorate in theology was awarded by the University of South Africa in 1996, and his name is listed among their notable alumni. ${ }^{2}$ Sanders has been at Hendrix College, Conway, Arkansas, since 2006 and he is currently Professor of Religion there. Hendrix College is affiliated with the United Methodist Church, their motto being "Unto the whole person," which is a translation of Ephesians 4:13b.

Since the 1970s, Sanders has endeavoured to settle in his own mind the biblical evidence concerning God's desire to save humankind on the one hand but, on the other, the seeming lack of accessibility of salvation to the unevangelised which raises questions about God's justice and the problem of evil. ${ }^{3}$

\footnotetext{
${ }^{1}$ Sanders, correspondence to C. Worsfold, 31 July 2009.

2 The University of South Africa is a Public Distance Education university, established in 1873, with a faculty of 4,000 and enrolled students numbering over 200,000.

${ }^{3}$ Sanders, No Other Name, xvii.
} 
In the mid-1980s Sanders wrote his first paper on this topic, in which he presented three views. ${ }^{4}$ He was encouraged to expand his ideas into a book, and spent the next six years researching the subject of the unevangelised. Questions regarding their final destiny frequently occupied the minds of his students but, more particularly, the same enquiry from his adopted daughter, centering on her birth mother, spurred Sanders on to attempt a more "complete answer." At the time of writing No Other Name, Sanders claimed that no studies on the subject had been published for over ninety years, and the pressing question remained.

Known as an evangelical Christian theologian, Sanders' inclusivist views include the affirmation that salvation and truth are to be found in other religions. He emphasises the significance of general revelation and believes that because all humankind is aware of creation, for example, the possibility is there for the unevangelised to be led to salvation. He supports the "fulfilment" theory which maintains that spiritual searching in non-Christian religions can be realised in Christian salvation. While rejecting the notion of salvation after death, Sanders teaches a "wider hope", meaning that salvation is accessible to all, including those who have never heard the gospel and, therefore, have not had the opportunity to express faith in Christ. In 2003, Sanders' support of "open theism" brought him into conflict with the Evangelical Theological Society (ETS) although he was permitted to remain in membership. ${ }^{5}$

\footnotetext{
${ }^{4}$ Ibid., xviii.

${ }^{5}$ On this see, for example, David Neff, “Open to Healing," Christianity Today (January 2004): 22-23.
} 
It should be noted here that Sanders prefers to refer to exclusivists as "restrictivists." He uses this term mainly because the view held within evangelicalism restricts the unevangelised to hearing the gospel and exercising faith in Christ before they die, otherwise there is no hope of salvation for them. ${ }^{6}$

\section{Inclusivist Considerations}

\section{(1) The Ontological/Epistemological Question}

Although there are variations in belief among evangelicals, one central tenet holds inclusivists together: salvation comes only through Jesus Christ. Sanders agrees with the central evangelical theological convictions that salvation is obtained through Christ alone; that salvation is the work of God's grace; that salvation is appropriated by faith. Evangelicals are on common ground in viewing the death and resurrection of Christ as the divine solution to the otherwise irreversible problem of sin. They affirm that salvation - and reconciliation with God - comes from Christ appropriated through faith on the part of the individual, and by the work of the Holy Spirit.

Differences arise between evangelical stances, however, on questions surrounding the level of knowledge required by an individual in order to experience salvation, whether salvation can be attained in non-Christian religions, and if the opportunity for forgiveness and reconciliation with God lapses at death. Inclusivists do not think it necessary to have specific knowledge of Christ's work, but that God works

\footnotetext{
${ }^{6}$ Sanders, No Other Name, 37. According to Sanders, the term "restrictivism" also means that access to salvation is not universal. Netland has discussed the difficulties with terms and notes that some have suggested "Particularism" in place of either "Exclusivism," or "Restrictivism." On this see, Encountering Religious Pluralism, 46-47.
} 
redemptively in the lives of all people. ${ }^{7}$ In the light of God's universal will that no one should perish, the point is made that salvation must be accessible to all. ${ }^{8}$

Sanders' analysis discusses six theological themes which concern the restrictive notions of biblical propositions: special revelation; the insufficiency of general revelation; the act of faith before death; the condemnation of those who reject the light they have; the motivation for missions and the universal accessibility of salvation. ${ }^{9}$ Although he affirms that exclusivism has strengths in upholding the particularity of salvation in Jesus Christ, the necessity of an act of faith, and the importance of missions, he believes that there is not sufficient weight given to the universal salvific will of God. If 1 Tim 2:2 is to be believed, there must be biblical ways in which God's desire for none to perish can be carried out. Some Scriptures support God's “universal desire for each and every human being who has ever lived, to experience redemptive grace." 10

Sanders agrees with exclusivists' belief in the ontological necessity of Jesus for salvation; there is no other way except through Christ, his cross and his resurrection. But epistemological necessity, firmly held by exclusivists, is dismissed. Is it necessary, given that God knows Jesus is the way to salvation, for believers in other religions to have that knowledge too? "Saving faith," replies Sanders, "does not

\footnotetext{
${ }^{7}$ Sanders, No Other Name, 241.

${ }^{8}$ Ibid., 216.

9 Ibid., 42-50.

${ }^{10}$ Ibid., 30.
} 
necessitate knowledge of Christ in this life."11 Again, "people can receive the gift of salvation without knowing the giver or the precise nature of the gift."12 There can be ignorance of the work of Christ, but the redemption he provides will still benefit the individual. $^{13}$

Exclusivists repudiate Sanders' position, arguing that Christ is both ontologically and epistemologically necessary for salvation. In support of this view, they refer to John 14:6, where the reported words of Jesus - "I am the way and the truth and the life" - show the epistemological necessity of Christ's salvific work. Sanders does not recognise any epistemological content here. On the contrary, while he agrees with exclusivists that salvation is obtained only through the atonement of Jesus, he states that "it is not certain from these passages that one must hear of Christ in this life to obtain salvation." 14 This position, which is also held by some other inclusivists, is refuted by the exclusivist, Ronald $H$. Nash. He contends that there is an epistemological component in the words "way", "truth" and "life"; none of these is of any worth, if one does not know of them. ${ }^{15}$ Nash believes that the stance which Sanders affirms disallows the redemptive work of Christ, and negates Jesus' own words which include the statement, "No one comes to the Father except by me."

\footnotetext{
${ }^{11}$ Sanders, No Other Name, 252.

12 Ibid., 215.

${ }^{13}$ Ibid., 282.

${ }^{14}$ John Sanders, "Is Belief in Christ Necessary for Salvation?," The Evangelical Quarterly 60 (1988): 246.

${ }^{15}$ Ronald H. Nash, Is Jesus the Only Saviour? (Grand Rapids: Zondervan, 1994), 147-148.
} 
In addition, contention exists between exclusivists and inclusivists because the former see the authority of Scripture, as well as the tradition of the Christian church, as being set aside. However, Sanders believes in the authority of Scripture. This means that the Scriptures are the source of Christian theology and Christianity's authority in everything to do with life and godliness. The Scriptures reveal God in creation, through the prophets of the Old Testament who spoke his will, and ultimately, in the culmination of the revelation of Christ as God's remedy for the sinfulness of humanity. The authority of Scripture is stressed by Sanders because he claims that exclusivists have accused "wider hope" proponents of placing human reason above biblical authority.

\section{(2) The Unevangelised}

The term "unevangelised" is used by Sanders in the hope that pejorative connotations of "pagan" and "heathen" will be avoided. He therefore refers to the unevangelised as those who have died without hearing about, or understanding, the redeeming work of Jesus Christ. Not all who hear will come to understand the gospel, for example, the mentally or psychologically incapable, and a recitation of "gospel facts" does not necessarily lead to an understanding of the gospel. ${ }^{16}$

There are differences of opinion between evangelical exclusivists and evangelical inclusivists on the position of the unevangelised, and variations of belief in both schools of thought. Some demand explicit knowledge and response to Christ which grants the individual assurance of salvation, while others do not wish to make

\footnotetext{
${ }^{16}$ Sanders, No Other Name, 15, n2.
} 
pronouncements on something which is unclear in Scripture. Some concede that there may be those whom God will save in spite of their not hearing the gospel. One of the most prominent evangelical scholars of the twentieth century, J. I. Packer, comments on this idea by saying:

We may safely say (i) if any good pagan reached the point of throwing himself on his Maker's mercy for pardon, it was grace that brought him there; (ii) God will surely save anyone he brings thus far; (iii) anyone thus saved will learn in the next world that he was saved through Christ. But what we cannot safely say is that God ever does save anyone in this way. We simply do not know. ${ }^{17}$

Again, other evangelicals hold to a "post-mortem" hope which will be discussed in Chapter Four.

\section{(3) General Revelation}

The problem surrounding the credibility of God's saving plan for humankind is not resolved, even though Sanders holds to two non-negotiable truths: (1) the finality of Jesus Christ, and (2) God's universal salvific will. This difficulty is partly addressed by the inclusivist contention that general revelation is sufficient for salvation - an emphasis that conflicts with exclusivist views, as exemplified by Netland. ${ }^{18}$ General revelation is understood to mean the disclosure of God in nature, in history and the moral law within every individual's conscience. Thus, it is available to everyone in all places and at all times. Even so, it is possible for the individual to fail to acknowledge the external evidences of God's eternal power and glory, and to refuse

\footnotetext{
${ }^{17}$ J. I. Packer, God's Words: Studies in Key Bible Themes (Downers Grove, IL.: InterVarsity Press, 1981), 210 .

${ }^{18}$ Netland, Encountering Religious Pluralism, 316-320.
} 
to recognise and to embrace God's witness of himself. This, then, becomes a point of contention between exclusivists and inclusivists.

Exclusivists create difficulties for Sanders by claiming on the one hand that general revelation confirms to the individual that he or she is condemned, whilst on the other hand denying that general revelation is sufficient for salvation. He rejects this distinction, arguing instead that if the source of general revelation is the saving God it must therefore be salvific. On this point, Sanders cites Alan Richardson, who contends that since all revelation is from God, all revelation is "saving revelation." Richardson maintains that "there is no such thing as a non-saving knowledge of God," but qualifies this by saying, "of course, it is not the complete knowledge of God, for this comes only by his special revelation through the prophetic history of Israel and its culmination in Christ." ${ }^{19}$ Revelation does not save or condemn, Sanders notes, but God does so, and individuals will experience salvation or damnation depending on their response to general revelation. This is in line with the inclusivist belief that general revelation, which dispenses knowledge of the Creator God, is brought about by God's own instruction (Rom 1: 18-19). There is no place for moral works or efforts to bring about salvation; inclusivist thought does not deny the sinfulness of human nature. ${ }^{20}$

Acceptance of general revelation as sufficient for salvation provides an answer to the inclusivist concern, articulated by Clark Pinnock, that exclusivists often present God "as if he did not care that most people perish through no fault of their own ... which

\footnotetext{
${ }^{19}$ Alan Richardson, ed. A Dictionary of Christian Theology (London: SCM Press, 1969), 295.

${ }^{20}$ Sanders, No Other Name, 234-235.
} 
distorts the nature of God and the heart of the good news."21 Gavin D'Costa, the Roman Catholic inclusivist, asks "Can we really accept that the God revealed in Christ ... has denied so many millions the means to salvation - through no fault of their own?" 22 Netland has acknowledged the troublesome nature of this question, but remains wary of embracing the inclusive idea of general revelation in response. Rather, he notes the diversity of evangelical opinion on the matters, and that disagreement has not been "definitively settled.",23

Others, however, have challenged the representation of exclusivist understandings in debates on this matter. Christopher Wright, Old Testament scholar and one time Principal of All Nations Christian College, Hertfordshire, labels the condemnation on those who have never heard of Jesus a "distortion" of the exclusivist view (that Christ is ontologically and epistemologically necessary for salvation). Salvation is for those who hear the gospel, and believe in Jesus. Wright points out that human sinfulness and wickedness is universal and those who finally experience God's wrath "will do so, not because of what they did not know and could not do (i.e. trust in Jesus), but because of all they did know and nevertheless did (i.e. sin against the light of conscience)." In other words, Wright maintains "nobody will go to hell because they have never heard of Jesus." ${ }^{24}$ Paul writes in this vein in Romans, where

\footnotetext{
${ }^{21}$ Pinnock, "An Inclusivist View," in More Than One Way? Four Views on Salvation in a Pluralistic World, ed. Dennis L. Okholm and Timothy R. Phillips (Grand Rapids: Zondervan, 1995), 143-144.

${ }^{22}$ Gavin D'Costa, Theology and Religious Pluralism: The Challenge of Other Religions (Oxford: Basil Blackwell, 1986), 67.

${ }^{23}$ Netland, Dissonant Voices, 264.

${ }^{24}$ Christopher Wright, The Uniqueness of Jesus, Thinking Clearly Series, ed. Clive Calver (London: Monarch Books, 2001), 43.
} 
evidence of human disregard for general revelation is presented. The passage in 1:18-32 refers to "what may be known of God" (v.19), "[God] being understood" (v.20), "they knew God" (v.21) and "knowing the righteous judgment of God" (v.32), all of which point to the knowledge of God that human beings possess, and understand with the mind.

Response to general revelation can determine an individual's destiny, Sanders believes, because God has directed human reasoning in the acceptance of knowledge of God. However, for exclusivists, this in no way deals with the world's sinfulness. General revelation, they say, reveals no path to salvation, nor leads to a change of heart from rebellion against God. The limitations of general knowledge noted above give way in exclusivists' thinking to the solution found in the sacrificial death of Jesus, which "satisfies" God's moral law and provides for the regeneration of humankind. While Sanders agrees that "all have fallen short of God's glory" and all are under God's judgment, he nevertheless claims that the first three chapters of Romans imply that individuals can respond appropriately to general revelation and so receive God's forgiveness. ${ }^{25}$ This approach eases the inclusivists' dilemma of finding a way to obtain salvation without an individual hearing the gospel.

Inclusivists take as an example Cornelius, a devout and God-fearing Gentile described in the book of Acts; one who Sanders sees as a "saved" believer prior to Peter's coming, did not know Christ or his saving work, but "became a Christian after receiving Christ and being baptised." ${ }^{26}$ Christopher Wright has a different

\footnotetext{
${ }^{25}$ Sanders, No Other Name, 235.

${ }^{26}$ Sanders, No Other Name, 222.
} 
perspective. The whole point of this story, he believes, was to show that Cornelius needed to hear the gospel. He writes that, "The detailed description of Cornelius' piety, generosity and prayers present him as, in a sense, the best that Gentile paganism could offer." ${ }^{, 27}$ Cornelius would never have received the specific gifts of forgiveness of sins (Acts 10:43), and of the Holy Spirit falling on him (v.44), if the special revelation of Jesus and the promise of salvation had not been brought to him by Peter. $^{28}$

However, the fear of God, and the righteousness Cornelius possessed had come about, in Sanders' view, through general revelation, which signalled the work of the Holy Spirit in the life of the unevangelised Cornelius. ${ }^{29}$ Exclusivists agree with inclusivists that the Holy Spirit is always at work in the world seeking to draw humankind to God, but argue that repentance, forgiveness of sins and the promise of the Holy Spirit in one's life, is not brought about by general revelation. They say that the pious life of Cornelius was evidence of preparation by the Holy Spirit for the further revelation of Jesus brought by Peter, and it was the knowledge of Jesus which gave Cornelius the joy of salvation.

According to Sanders, Cornelius became a "Christian believer" following Peter's preaching, his subsequent acceptance of the same, and his baptism. "To argue that Cornelius could not have been saved, is to exhibit precisely the sort of narrowness

\footnotetext{
${ }^{27}$ Christopher J. H. Wright, "The Christian and Other Religions," Themelios 9 (February 1984): 14.

${ }^{28}$ Ibid.

${ }^{29}$ Sanders, "Is Belief in Christ Necessary for Salvation?," 254.
} 
that God worked to overcome in the early Jewish church." ${ }^{30}$ However, to infer that Cornelius was saved by his own righteousness is not inclusivists' intention. If this were so, they would be saying that Cornelius' virtuous life, his right standing and behaviour in the community, had saved him. But inclusivists do maintain that "it is not necessary to understand the work of Christ to be saved" and see the story of Cornelius as supporting their view, that the unevangelised may be saved by Christ, without their knowing about Christ.

Exclusivists, on the other hand, maintain that certainty of Cornelius' saved status is stated in Acts 11:14. It is contended that Cornelius, pious and full of good works though he was, still needed to heed the "divine instruction" (Acts 10:22, 33) and to hear "all the things commanded by God", delivered by Peter (vv. 34-41). "Remission of sins" (v.43) followed acceptance of the word, the "Holy Spirit fell on all who heard the word" (v.44) and they were "commanded to be baptised" (v.48).

It is argued by exclusivists that Paul's writings to the Romans (Rom 1:20-23) and also to the Corinthians ( 1 Cor $1: 21 ; 2: 8$ ) do not support the idea that general revelation alone can lead to a precise understanding of the predicament of humankind, or of God's requirements for reconciliation. Rather, general revelation gives to humankind an awareness of the Creator God, but not of the saving God. The innate moral conscience which humans possess may, or may not, be heeded. Because sin entered the world, the image of God in humankind has been marred. Exclusivists do not accept that general revelation of God in nature, history and moral conscience

\footnotetext{
${ }^{30}$ Sanders, No Other Name, 222.
} 
offers a way of bridging the gulf between a righteous God and sinful humanity. It was necessary for God's plan of salvation to be presented, first, in the Old Testament prophecies and then, more fully, in God's revelation of Christ and the salvation offered to humanity through Christ's sacrificial death and resurrection.

The inclusivist position, however, is that general revelation can draw an appropriate response from human beings, and that special revelation is not necessary in order that salvation be granted to an individual. What then is the significance of special revelation?

\section{(4) Special Revelation}

Some exclusivists, Netland for example, consider that in specific cases of Old Testament characters (including, but not limited to the patriarchs and prophets), special revelation was afforded them because God "appeared to, or otherwise communicated with" them in some way. ${ }^{31}$ Suffice it to say that the message of the church has always been that the complete and highest revelation of God the Father is seen in Jesus Christ. Wolfhart Pannenberg illustrates this point:

The Christian tradition affirms that it is precisely through the biblical witness and definitively through Jesus Christ that this God is known to us. It does not deny that there is some dim and provisional knowledge of God in all humankind, but even the fact that it is this one God who is also otherwise known in provisional ways, can be stated only on the basis of his revelation in Christ.",32

\footnotetext{
${ }^{31}$ Netland, Encountering Religious Pluralism, 318.

${ }^{32}$ Wolfhart Pannenberg, "Religious Pluralism and Conflicting Truth Claims," in Christian Uniqueness Reconsidered: The Myth of a Pluralistic Theology of Religions, ed. Gavin D'Costa (Maryknoll, NY.: Orbis, 1990), 97.
} 
Today, special revelation usually refers to the text of the Bible, "the sacred writings that are able to instruct you for salvation through faith in Christ Jesus." 33 It is in Christ Jesus that God's special revelation has been given definitive shape. In addition, the Scriptures need to be heard or read in order for God to reveal himself in Jesus Christ, the incarnate Word of God. Peter confirms that the Old Testament Scriptures taught the early church God's plan of redemption. "Concerning this salvation," he writes, "the prophets ... made careful search and inquiry."34

In No Other Name, Sanders examines a number of biblical texts which exclusivists understand to affirm that unless special revelation of the gospel is received by an individual, there is no salvation. ${ }^{35} \mathrm{He}$ also considers further texts which underline the importance of hearing the gospel and repenting of sin, and the narrowness of the path to God. These Scriptures, Sanders contends, present a "bleak picture of humanity out of reach of the gospel." 36

According to Sanders, Old Testament believers enjoyed the same forgiveness as Christian believers today. God is the object of Christians' faith as he was in Abraham's experience, and the trust in God that Christians practice is identical with that of Abraham and David. However, others note that, in the case of Abraham, Scripture states that he believed God and it was reckoned to him for righteousness. ${ }^{37}$

\footnotetext{
${ }^{33} 2 \operatorname{Tim} 3: 15$.

${ }^{34} 1$ Pet $1: 10$.

${ }^{35}$ Sanders, No Other Name, 39-41.

${ }^{36}$ Ibid., 41.

${ }^{37}$ Rom 4:22.
} 
His obedience was response to the divine revelation through special messengers and through the covenant God made with him and his descendants. Carson points out that "these believers on the Old Testament side were responding in faith to special revelation, and were not simply exercising some sort of general faith in an undefined God." ${ }^{38}$ Nevertheless, Sanders maintains that the Scriptures do not enunciate the precise amount of knowledge required for salvation. All "believers" have Christ implicitly, whether they were Old Testament or unevangelised people of faith. ${ }^{39}$

\section{Universally Accessible Salvation versus Universalism}

Sanders' view of the "destiny of the unevangelised" emphasises the notion of a universally accessible salvation. His plea for a more open proclamation of this salvation by the church is based at least in part on the unprecedented "wider hope" position of the apostle Paul in his dealings with the Gentiles (Acts 15:23-29). As Sanders points out, however, there is some difficulty among exclusivists on the difference between universally accessible salvation and universalism. The latter view is not one which Sanders upholds. Universalism endeavours to reconcile the scope of God's salvific will with the lost state of the unevangelised optimistically, teaching that all will be redeemed regardless of belief or behaviour. Universalism maintains that no human being will be eternally separated from God, for being under God's condemnation is not a final state and because justification will ultimately be applied to all people. ${ }^{40}$ The notion of universalism has been welcomed in many areas of the

\footnotetext{
${ }^{38}$ Carson, The Gagging of God, 298.

${ }^{39}$ Sanders, "Is Belief in Christ Necessary for Salvation?," 259.

${ }^{40}$ Sanders, No Other Name, 84.
} 
Christian community and Sanders suggests this is because the "harsh, unloving God of exclusivism" is one extreme to be deplored, but the "loving God of universalism" is a more palatable choice. ${ }^{41}$

Although attractive in some respects, the case for universalism lacks biblical evidence. If the teaching of universalism were to be seriously considered, Sanders believes it would be necessary to dispense with a number of traditional Christian concepts. For example, universalists do not make it clear that while Christ died for all, salvation is only for those who believe. ${ }^{42}$ Universalism is also unclear about the act of faith which is necessary to appropriate that salvation (Rom 5:17). ${ }^{43}$ A third difficulty in universalism's arguments is that the Scriptures indicate eternal separation from God for those who remain impenitent (Matt 25:46). ${ }^{44}$ There are numerous warnings in Scripture which refer to God's final judgment and the hopelessness for those "who ultimately reject God's grace." ${ }^{45}$ The universalist claim that there will be no final impenitents lacks an understanding of divine judgment and the purpose of hell. In fact, Sanders asserts, universalism has no biblical basis: "The Bible seems to provide substantial warrant for the concept of divine retributive justice. ${ }^{" 46}$ His inclusivist stance suggests that the universal accessibility of salvation is all that is needed to harmonise God's universal salvific will and the plight of the

\footnotetext{
${ }^{41}$ Ibid., 106.

${ }^{42}$ Ibid., 107.

${ }^{43}$ Ibid.

${ }^{44}$ Ibid., 114.

${ }^{45}$ Ibid., 109.

${ }^{46}$ Sanders, No Other Name, 114.
} 
unevangelised. Thus, salvation of the unevangelised is possible without adopting a universalist position. ${ }^{47}$ Sanders remains opposed to universalism, but insists that salvation must be universally accessible and hence obtainable without the knowledge of Christ. $^{48}$

Sanders agrees that the "wider hope" theory mentioned above is not clearly taught in the Old Testament, but criticism of the ideas, including the necessary distinguishing of "believers" from "Christians," does not unduly concern Sanders. In his opinion some degree of cognitive informative is required for saving faith but he maintains that only Christians have knowledge about the name of Jesus. "Believers have not experienced salvation in its fullness" as they have not become aware of the work of Christ. ${ }^{49}$ Charles Kraft argues that although "allegiance to God is central to the message, God allowed in Scripture, and allows today, for a range of understanding of himself." God reveals himself to people who move toward a given goal on a "directional" basis rather than a "positional" one: that is to say, God is not concerned with the specific knowledge individuals possess but, rather, the direction in which they are headed. ${ }^{50}$ Exclusivists resist this distinction between believer and Christian, for they reject the idea that salvation may be experienced apart from knowledge and confession of Christ.

\footnotetext{
${ }^{47}$ Ibid., 107.

${ }^{48}$ Ibid., 137.

${ }^{49}$ Ibid., 229-230.

${ }^{50}$ Charles Kraft, Christianity in Culture: A Study in Biblical Theologizing in Cross-Cultural Perspective, $2^{\text {nd }}$ ed. (Maryknoll, N.Y.: Orbis Books, 2005), 186-187.
} 
While Sanders dismisses ideas of an opportunity to obtain salvation after death, he reiterates, "if God intends this salvation to be genuinely universal, then it must be possible for every individual who has ever lived personally to receive that salvation regardless of the historical era, geographical region or cultural setting in which these people have lived." ${ }^{51} \mathrm{He}$ is unsympathetic to theologians who prefer to take an agnostic viewpoint on the wider hope as defined early in this chapter, observing that there is "a desire to relieve the tension on this issue, without paying the theological price." 52

\section{Open Theism}

The doctrine of God as understood by evangelicals came under scrutiny in the late twentieth century, partly as the result of a search for a compromise between what was considered to be an exaggeration of God's transcendence, and ideas which insisted on radical immanence. ${ }^{53}$ It is fair to say at this point that all inclusivists are not open theists, but all open theists are inclusivists. Among the open theists there was a desire for a literal give-and-take relationship between God and human beings so that God was not viewed as "an aloof monarch" but rather, as a "caring parent."

\footnotetext{
${ }^{51}$ Sanders, No Other Name, 216.

52 Ibid., 77.

${ }^{53}$ Clark Pinnock, "From Augustine to Arminius: A Pilgrimage in Theology," in The Grace of God and the Will of Man, ed. Pinnock (Minneapolis: Bethany House Publishers, 1995), 26.
} 
Sanders was one of the five evangelical theologians who contributed to The Openness of God which will be discussed more fully in Chapter Four. ${ }^{54}$

As an open theist, Sanders has sought a more acceptable interpretation of the problem of human suffering and how God relates to humankind. His search extends to that part of the problem of evil which is the final destiny of the unevangelised. It is an unsatisfactory situation, in that this subject has never reached a consensus of opinion at any stage in the history of the church. There were disputations in the early church concerning the salvation of the unevangelised Gentiles, for example, but no decisive pronouncement was made, nor has it since. ${ }^{55}$ For Sanders, the pressing question of the unevangelised is interwoven with his open theistic views of the attributes of God as discussed below, while keeping hold on two essential truths: the particularity of salvation only through Jesus, and God's universal salvific will. ${ }^{56}$

Development of the open theistic school of thought has been marked by deep division between evangelicals. Arguably, the most controversial departure from orthodox Christian doctrine propounded by open theism concerns the exhaustive foreknowledge of God. This particular debate has contributed significantly to the process of fragmentation in evangelicalism and shows little sign of losing impetus. God's foreknowledge is limited, open theists say, to the degree of probability, because the future depends on the choices human beings have not yet made. This

\footnotetext{
${ }^{54}$ Clark H. Pinnock, Richard Rice, John Sanders, William Hasker and David Basinger, The Openness of God: A Biblical Challenge to the Traditional Understanding of God (Downers Grove, IL.: InterVarsity Press, 1994).

${ }^{55}$ Sanders, No Other Name, 18.

${ }^{56}$ Ibid., 25-27.
} 
follows open theistic ideas of human free will which suggest that God is in a selfimposed position of risk. This, in turn, impinges on the historic Christian doctrine of the sovereignty of God, and the authority of Scripture which portrays the nature of God. Justin Taylor asserts that the open theism debate is not concerned with "minutiae or peripheral matters" but is a debate "about God and the central features of the Christian faith." ${ }^{57}$ To the evangelical who takes a position on historic Christian doctrine, open theism suggests that God is not sovereign, not immutable, not all-knowing or infinite in power.

In his teens, Sanders was deeply affected by the accidental death of his brother. ${ }^{58} \mathrm{He}$ describes his dismay at being presented (when at Bible College) with a view of God's nature which immediately raised questions for him. The idea that God was not affected by his creatures, and never responded to them in any way, was contrary to the "evangelical piety" which he had practiced, and had believed was supported by Scripture. After two decades of wrestling with the theological arguments concerning God's interaction with humankind, Sanders came to the conclusion that there was need for some modification.

His most developed explanation of open theism begins with the broad statement "that God is open to what creatures do." ${ }^{, 59}$ Sanders presents a triune God who is

\footnotetext{
${ }^{57}$ Justin Taylor, "Introduction," in Beyond the Bounds: Open Theism and the Undermining of Biblical Christianity, ed. John Piper, Justin Taylor, and Paul Kjoss Helseth (Wheaton, IL.: Crossway Books, 2003), 13.

${ }^{58}$ Christopher A. Hall and John Sanders, Does God Have a Future? A Debate on Divine Providence (Grand Rapids: Baker Academic, 2003), 11.

${ }^{59}$ Sanders, The God Who Risks: A Theology of Providence, rev. ed. (Downers Grove, IL.: InterVarsity Press, 1998), 14.
} 
loving, almighty, and sovereign over all. Because of his sovereignty, God had the freedom to create human beings with freedom of will, so that a relationship of love would be formed between God and human beings. The libertarian nature of the latter means that God's intentions towards them are not always realised. Human beings are not tightly controlled by God in all that takes place; God takes risks, changes his plans and cooperates with human beings to bring about his plans for the future. ${ }^{60}$ Thus, it is God and humans who decide the future. In open theistic thought God knows all that is possible to be known. That is, the past and present are known to God comprehensively, but the future is partly open and partly closed to God's knowledge. The decisions of human beings have a bearing on what happens in the future. $^{61}$

Although he was not the first to advance open theistic ideas, Sanders met with considerable opposition from evangelicals. He attracted publicity through his connection with the ETS, whose members largely disagreed with these notions. Both Sanders and Clark Pinnock, whose views will be examined in the next chapter, had formal charges brought against them in 2002 by founding ETS member Roger Nicole, who labeled open theism as "a cancer on the soul of the ETS."62 Christianity Today reported that previous discussions with Sanders centred "on his belief that biblical prophecies were not certain (since God does not actually know the future),

\footnotetext{
${ }^{60}$ Sanders, The God Who Risks, 14-15.

${ }^{61}$ Hall and Sanders, Does God Have a Future?, 12-13.

${ }^{62}$ Neff, “Open to Healing," 21.
} 
but were instead probabilistic." ${ }^{, 63}$ It was agreed by the ETS committee that this meant Sanders' affirmation of biblical inerrancy "implied something quite different" from the ETS doctrinal basis. The Society failed, however, to define inerrancy, which enabled both Sanders and Pinnock to remain in membership. ${ }^{64}$

The accusation is made by Robert B. Strimple that open theism has been revived from the writings of Faustus Socinus (1539-1604) and that at least one of its central tenets has its roots in Socinianism. ${ }^{65}$ Socinus maintained that future decisions to be taken by individuals with freedom of will were not yet knowable, and God's omniscience did not allow him to foreknow these decisions. This idea is held by open theists, but Sanders rejects the association with Socinianism because they also denied doctrines such as the deity of Christ, his atoning death and justification through Christ's righteousness. These are quite clearly part of Sanders' beliefs, and accord with historic evangelical teachings.

Sanders was still formulating his open theistic ideas in the early 1990s when he wrote that, "The Bible presents us with a God who makes himself vulnerable by creating creatures who have the freedom to reject him. This God takes risks and leaves himself open to being despised, rejected and crucified." ${ }^{66}$ A decade later, Sanders gave two concise definitions. The first was of classical theism, which

\footnotetext{
${ }^{63}$ Neff, "Open to Healing," 22.

${ }^{64}$ Ibid., 22.

${ }^{65}$ Robert B. Strimple, "What Does God Know?," in The Coming Evangelical Crisis: Current Challenges to the Authority of Scripture and the Gospel, R. Kent Hughes and John H. Armstrong (Chicago: Moody Press, 1996), 139-153.

${ }^{66}$ Sanders, No Other Name, 112.
} 
affirms God's immutability, impassibility, timelessness, sovereignty and exhaustive foreknowledge: God's will never fails, neither does he take risks, and the desires of humankind are determined by the will of God. ${ }^{67}$ It was this model that was troublesome for Sanders at the time of personal grief. The second definition concerned open theism, which, for him, reveals God's "flexible strategies" that accommodate the libertarian freedom God has given human beings. ${ }^{68}$ The gracious God, Sanders believes, invites human beings to "collaborate" in bringing about that open part of the future. ${ }^{69}$ This idea goes some way toward relieving the tension between the classical theology of the sovereignty of God, and the openness school of thought which upholds the freedom of the human will and its relationship to God, and the nature of the future.

Most would agree that Scripture is not explicit on every issue, and that some issues are more important than others. By the same token, exclusivists contend that there are "clear and dominant themes" which are informative regarding the doctrine of God, and therefore would, ideally, form the foundation of an evangelical theology of religions. ${ }^{70}$ However, there are significant differences within evangelicalism on aspects of open theistic ideas. Arguably, none is more strenuously debated than the doctrine of the omniscience of God. This is a significant shift from historic evangelical doctrine but one from which other openness of God theories flow. On

\footnotetext{
${ }^{67}$ Hall and Sanders, Does God Have a Future?, 201-202.

${ }^{68}$ Ibid., 203-204.

${ }^{69}$ Ibid., 13.

${ }^{70}$ Netland, Encountering Religious Pluralism, 315.
} 
this view, a God who knows the future and determines his purposes is not an open God. Therefore, open theism depicts a God who adjusts to the actions of freewill human beings and fosters a give-and-take relationship as the future is shaped together. The evangelical concern is that the desire to preserve the freedom of human beings overrides the biblical portrayal of an all-wise, all-knowing God. This in turn leads to the necessity of reducing the God of Scripture to what, in human thought, God should be. It is a pluralist concept which is also seen in pluralism's calls for the diminishing of Jesus who no longer occupies the central place.

Sanders makes the point that "saving faith involves the process of moving some truths about God's character to a degree of trust in the person of God that results in obedience to his will." ${ }^{, 71}$ In opposition to this idea, Ramesh Richard suggests that the need for trust in Jesus is removed as being inconsequential, or at least irrelevant. ${ }^{72}$ Again, "Pluralism," Christopher Wright observes, "has some major implications which set it totally at odds with biblical Christianity and make it actually a particularly dangerous philosophy for Christians to toy with ... [it undermines] our understanding of God, Jesus, the New Testament and the worship of Christians themselves." ${ }^{, 73}$ In the light of the opinions given above, it is not surprising that the

\footnotetext{
${ }^{71}$ Sanders, No Other Name, 228.

${ }^{72}$ Ramesh P. Richard, The Population of Heaven: A Biblical Response to the Inclusivist Position on Who Will Be Saved (Chicago: Moody Press, 1994), 70, n20.

${ }^{73}$ Wright, The Uniqueness of Jesus, 76.
} 
open view on the omniscience of God has been described by Sanders as the "lightning rod for criticism of the [openness] model.",74

\section{(1) Omniscience of God}

Sanders presents a concept for which he coined the term "dynamic omniscience." By this he means that God possesses exhaustive knowledge of the past and present, but the future is not something that already exists. It unfolds as God creates it together with human beings whose future actions are unknowable. Therefore, God knows the future only as partly definite (closed) and partly indefinite (open). "God's omniscience is dynamic in nature." 75

Classical theists have criticised this notion. Bruce Ware, for example, claims that Christians would (1) gain an exalted idea of their own contribution to the unfolding future at "the expense of God's diminished knowledge, wisdom and certainty" (2) that denying the exhaustive foreknowledge of God would "dishonour and belittle the true and living God." ${ }^{, 77}$ That assertion is not accepted. Sanders argues that because God sees the future as a partly open and partly closed reality, and because God freely chooses not to have a completely closed future (and thus possess exhaustive definite foreknowledge), God is not diminished in any way. ${ }^{78}$ He favours

\footnotetext{
${ }^{74}$ Sanders, The God Who Risks, 16.

75 Ibid.

${ }^{76}$ Bruce Ware. "Defining Evangelical's Boundaries Theologically: Is Open Theism Evangelical?," Journal of the Evangelical Theological Society 45:2 (June 2002): 211.

${ }^{77}$ Ibid., 199.

${ }^{78}$ Sanders, The God Who Risks, 84.
} 
the concept of a "give-and-take" relationship between God and humanity, whereby each respond to possibilities arising from the present. The future is then akin to God and his creatures writing their own "story book." 79 Open theism concedes that it is entirely possible for God to know the future comprehensively but maintains that he did not choose to do so. If he had, they say, it would have meant an absence of libertarian freewill with God tightly controlling every detail in the world. "God cannot know as definite what we will do," Sanders contends, "unless he destroys the very freedom he granted us." ${ }^{, 80}$

It is not possible to discuss here many of the Scriptural references to omniscience. Arguably, however, some of the best known Old Testament passages in this regard are contained in Isaiah 40-49. In the evangelical tradition these chapters are generally acknowledged as portraying the sovereign God who knows the future comprehensively. The contrast is being made between the false idols, which Israel was tempted to worship, and the Living God. The claims of God in Isaiah include:

I am God and there is no one like Me, declaring the end from the beginning, and from ancient times things that are not yet done, saying, "My purpose shall stand, and I will fulfill my intention" (Isa 46:9-10). For thus says the high and lofty one who inhabits eternity, whose name is Holy: "I dwell in the high and holy place" (Isa 57:15).

Sanders does not see the text Isaiah 46:9 as meaning anything more than that "the end" is the end of exile in Babylon. He observes that references such as the above do not teach the exhaustive definite foreknowledge of God, although he agrees that it

\footnotetext{
${ }^{79}$ Sanders, The God Who Risks, 207.

${ }^{80}$ Ibid., 206.
} 
could be a possible reading. ${ }^{81}$ For Sanders, God is no less great because he changes his mind as a result of having been "affected (and sometimes surprised) by his creatures." He maintains that the description of God's nature includes the ability to change his mind, "alongside graciousness as a key descriptor of God." 82 On one hand, there is the idea of the omniscient God who lacks exhaustive foreknowledge and changes his mind as he relates to human situations, while on the other hand, orthodox Christianity argues that God's omniscience can be harmonised with the human responsibility of exercising free will and the subsequent results from the latter. These questions constitute the greatest contrast and difficulty between open theism and evangelical tradition with their respective versions of biblical truth.

Openness theologians emphasise that the "absolutistic conception of God" actually derives from the writings of the Greek philosophers, Plato and Aristotle, and their perceptions of God. Many of their ideas were taken from Philo's writings, ${ }^{83}$ which influenced the early church fathers and assisted them to convey the Christian message and establish credibility. ${ }^{84}$ Based on these ideas of God's impassibility, immutability and timelessness, the church developed descriptions of God which were considered to be superior to anthropomorphic ways of stating beliefs about the nature of God. These notions have had a long-standing acceptance and the church has taken them as right and proper. However, Sanders explains, openness theology

\footnotetext{
${ }^{81}$ Sanders, The God Who Risks, 79.

${ }^{82}$ Hall and Sanders, Does God Have a Future?, 156.

${ }^{83}$ On this Jewish exegete, thinker and spiritual leader, see "Philo," in The Oxford Dictionary of the Christian Church, ed. F. L. Cross (London: Oxford University Press, 1958), 1065.

${ }^{84}$ Sanders, "God as Personal," in The Grace of God and the Will of Man, ed. Pinnock, 170-171.
} 
does not believe that the essence of God changes, but that God does change in experience, knowledge, emotions and actions. ${ }^{85}$

Sanders argues that the early church fathers' conception of God should be set aside in favour of the "personal view" of God who is revealed by the many metaphors in Scripture and who "will never be less than or contrary to, a personal being." 86 According to Terence Fretheim, this personal God is one:

Who knows all there is to know about the world, but there is a future which does not yet exist to be known even by God. God is Lord of time and history but God has chosen to be bound up in time and history of the world and to be limited thereby. God is unchangeable with respect to the steadfastness of his love and his salvific will for all creatures, yet God does change in the light of what happens in the interaction between God and the world. ${ }^{87}$

The personalistic interpretation of the Scriptures which Sanders supports speaks in metaphor of Yahweh's relationship with humankind and suggests that Yahweh should be seen as the "defenceless superior power." 88 This means that although Yahweh has set the rules in place, he made himself vulnerable, or defenceless, and willing to take the risk of his will not being accomplished. ${ }^{89}$ Here, the "dynamic omniscience" mentioned earlier appears. Yahweh is seen as granting human beings some of his power so that humanity is not a merely passive partner. The future, not exhaustively known by God, can change depending on human responses to the

\footnotetext{
${ }^{85}$ Sanders, The God Who Risks, 187.

${ }^{86}$ Sanders, "God as Personal," 174.

${ }^{87}$ Terence E. Fretheim, The Suffering of God: An Old Testament Perspective (Philadelphia: Fortress Press, 1984), 35.

${ }^{88}$ Sanders, "God as Personal," 175. Italics are in the original.

${ }^{89}$ Ibid., 174.
} 
divine will, but the covenant relationship between Yahweh and human beings is uppermost in Yahweh's responses. "Both parties," writes Sanders, "are creating the future." However, the covenant partners are not equal, for it is God who is the initiator. $^{90}$

The above discussion gives only a glimpse of major theological disagreements in the evangelical world. Although Sanders regards the Bible as his "final guiding belief" and the authoritative norm for theology, he employs "critical interpretationism" and encourages all evangelicals to apply themselves to interpret the Scriptures, to debate new ideas, to be willing to modify, or even reject, certain "control beliefs." 91 The difficulty is, however, that to modify or reject these beliefs, for example, the omniscience of God, marks a departure from the historical thought of orthodox Christian faith. While this does not seriously concern some inclusivists, exclusivist evangelicals deplore the situation. Bebbington has pointed out that until the eighteenth century, the beliefs of the Christian church were accepted as being contained in the Bible, and there was agreement among evangelicals "of all generations that it is inspired by God." "92 For exclusivists, Sanders' ideas of reducing the importance of historical Christian belief, present not only a reformulation of the understanding of God, but is also an unworthy portrayal of God.

\footnotetext{
90 Sanders, “God as Personal,” 178.

${ }^{91}$ Sanders, No Other Name, 32.

92 Bebbington, Evangelicalism in Modern Britain, 12-13.
} 


\section{(2) Immutability and Timelessness}

In The God Who Risks, Sanders examines Augustine's theology on this issue of immutability, and finds that Augustine gave no ground to the notions of God's knowledge ever changing, nor his will ever being altered. ${ }^{93}$ This means that God does not have the give-and-take relationship with humanity which the openness theology advances, and Sanders notes that the idea of "divine risk taking" is discounted. ${ }^{94}$ Sanders claims that Augustine contributed significantly to what became known as "classical theism." This was, God as "strongly immutable and impassible, timeless and simple." 95 It follows from the latter statement that there is no libertarian freedom such as the openness theory teaches. It is not unexpected that Sanders refutes this Augustinian viewpoint, and insists that it is precisely because of Yahweh's steadfast love that he can change in dealing with his people (Hos 11:8-9).

Berkhof's phrase "changeable faithfulness" is borrowed for it demonstrates and explains Yahweh's faithfulness to his salvific plan, while his changeableness is in his feelings, plans, and actions in responding to humanity. ${ }^{96}$ In any case, Sanders' belief is that an absolutely immutable God is not essential to Christianity - it "only requires a faithful God." ${ }^{97}$ For opponents of open theism, a denial of immutability would lead to a concept of severe limitation of God's knowledge and make way for error on

\footnotetext{
${ }^{93}$ Sanders, The God Who Risks, 149.

${ }^{94}$ Ibid., 153.

95 Ibid.

${ }^{96}$ Hendrikus Berkhof, Christian Faith: An Introduction to the Study of Faith (Grand Rapids: Eerdmans, 1979), 140.

${ }^{97}$ Hall and Sanders, Does God Have a Future?, 128.
} 
God's part, reducing God to human proportions. This would be unacceptable to those who hold that God's knowledge of the future is exhaustive, from ancient times revealing the end from the beginning (Isa 46:10-11). Immutability means that God cannot change from his state of absolute perfection, for this must mean that there would be either an impairment of his power, or an improvement on the already perfect state.

The Abraham story is used to support the openness notion of a risk-taking God. Rather than the proving of Abraham's faith towards God, Sanders writes that: "God needed to know"; "God has some lingering doubts"; "God intends to discover which trajectory Abraham is on"; and, "God takes the risk that Abraham will exercise trust." $" 98$ This view remains problematic for more conservative evangelicals. For them, timelessness means that God is eternal, without beginning or end, and is outside or beyond time. Traditional Christianity teaches that although God dwells in time, he is not confined to time but rather, transcends it. He created a world of space and time while not having his own beginning there, for his life is from within himself. His presence fills and sustains the world of space and time. Sanders writes that open theism denies divine timelessness, ${ }^{99}$ and in his larger and later work, The God Who Risks, Scriptures which relate to God's infinity have not been discussed.

There are several theories concerning God's relationship to time on which proponents of open theism disagree. The view of God which Sanders favours is that of "a personal agent who experiences the give-and-take of historical life with his

\footnotetext{
${ }^{98}$ Sanders, The God Who Risks, 51.

${ }^{99}$ Hall and Sanders, Does God Have a Future?, 139-140.
} 
creatures." ${ }^{\prime 100}$ Because God changes as he relates to humankind, God has a history. "God experiences temporal sequence of one event happening after another. God is everlasting in that he was, is, and will be."101 But, Sanders states, "God is not timeless since a timeless being has no history." 102 In Sanders' thought, there are actions which a timeless being is unable to do, such as plan, deliberate, have changing emotions, adjust plans, anticipate or respond. ${ }^{103}$ This is countered with the statement that there is no logical difficulty in saying that God does do all the above. While God is unchangeable in his character, Sanders agrees with Nicholas Wolterstorff:

God the Redeemer cannot be a God eternal. This is so because God the Redeemer is a God who changes. And any being which changes is a being among whose states there is temporal succession. Of course, there is an important sense in which God as presented in the Scriptures is changeless: he is steadfast in his redeeming intent and ever faithful to his children. Yet, ontologically, God cannot be a redeeming God without there being changeful variation among his states. ${ }^{104}$

It has been pointed out previously that open theists believe God has emotions which change, as do his actions and will; God responds to humanity and suffers because of their rejection of him. ${ }^{105}$ A difficulty arises when it is agreed that change involves time. Because of the fact that open theists hold to the above view of change which negates the traditional notion of immutability, it cannot then be said that God is

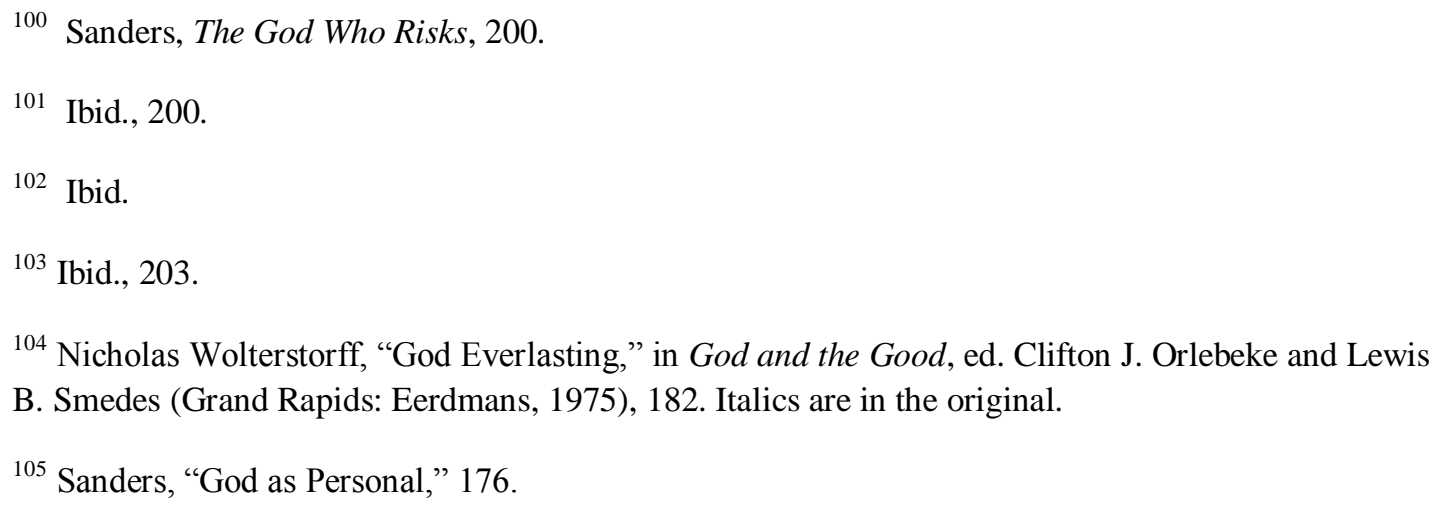


timeless. Neither can the latter be said if his foreknowledge is denied. Combined with immutability and timelessness, in particular, these doctrines form part of what evangelicals know as the "substance" or "essence" of God. None can be dispensed with and, at the same time, retain what is known as traditional Christian and evangelical belief. This means, then, that foundational truth held by historic branches of the Christian church is, in part, dismantled by open theistic ideas. However, Sanders, along with other evangelical Christians, agrees that the central tenet is the gospel with the attendant beliefs of the sacrificial death and resurrection of Jesus, and reconciliation to God which results in a godly life.

\section{Summary}

This examination of Sanders' theology has shown that, at certain points, he has moved away from the historical roots of Christian theology. The desire to find a way to solve the problem of the salvation of the unevangelised, to retain the freedom of the individual and to shake off the perceived influence of Greek philosophers, has led Sanders to take divergent paths. His search for inclusive ways to present salvation to those who have never heard the gospel has opened the door to possibilities unacceptable to traditional evangelicals mainly because of what they see as paucity of Scriptural basis. This is particularly so in the matter of the ontological/epistemological debate. More credence has been given to the scope and efficacy of general revelation than traditional evangelicalism has historically allowed. In Sanders' view, this argument gives added credibility to God's saving plan for humankind. It has been noted previously that in inclusivist thinking, general revelation has a mediatorial role to play. That is, while the finality of salvation is 
only in Christ, the knowledge of Christ's work is unnecessary. ${ }^{106}$ "God uses general revelation to mediate his salvific grace," writes Sanders. ${ }^{107}$ This belief founders on the idea that, by mediating salvation, general revelation presents truth equally to everyone. Richard explains that the pluralist dogma of modernity teaches it is only fair for truth to be equally present to everyone, and that the ultimate reality will be known by everyone, even if only vaguely. ${ }^{108}$ "Mediatorial general revelation supposedly presents truth equally and simultaneously to everyone," continues Richard. "There is one God and one mediator between God and man, namely, general revelation. General revelation has assumed the role of Christ." ${ }^{109}$ This point of view does not accord with historic evangelicalism which believes that salvation is an act of unmerited divine grace received through faith in Christ.

Sanders does not see the need to dismiss pluralistic ideas concerning divine involvement in other non-Christian religions but, on the contrary, has embraced them. At the same time, he upholds the uniqueness and finality of Jesus, arguing that, "God is redemptively at work in the lives of all people." ${ }^{110}$ Some would take issue with Sanders' statement that the early Christians rejected many of the ways the pagans worshipped but not who they worshipped. ${ }^{111}$ On the contrary, in that religiously plural world there were "many lords and many gods," Lesslie Newbigin

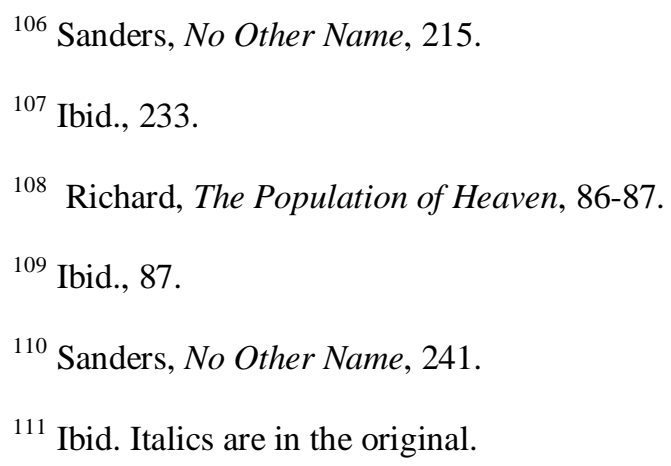


points out, "and Christians had to work out what it means that in fact Jesus alone is Lord." 112

Notwithstanding these innovations, there are significant areas of agreement between Sanders' theology and the stance of Harold Netland, as well as with other exclusivists covered in the preceding chapter. Specifically, Sanders emphasises his concurrence with "traditional evangelical theology" as expressed in his affirmation that "salvation is offered only through the work of Christ, a complete work of God's free grace, that is it appropriated only by faith, and that the Bible is the final authority for faith and practice." ${ }^{\prime 13}$ On the other hand, Sanders together with other open theists, is willing to set aside orthodox evangelical understanding of some doctrines as discussed above. Both schools of thought believe that Scripture supports their view. The ontological/epistemological differences surrounding the matter of salvation remain unresolved between them. The same is true of the question concerning the necessity of both general and special revelation in regard to salvation. The weakening of, or even departures from, traditional Christian doctrine is seen as having unwelcome consequences, importantly, for the perception of the sovereignty and certain attributes of God. The open theistic denial of God's exhaustive foreknowledge and the concept of a risk-taking God opposes the orthodox Christian belief in God's comprehensive knowledge of the past, present and future. These debates have played an important part in the process of disturbing the historic evangelical movement's degree of theological unity. They have produced confusion,

\footnotetext{
${ }^{112}$ Lesslie Newbigin, The Gospel in a Pluralist Society (Grand Rapids: Eerdmans, 1989), 157.

${ }^{113}$ Sanders, No Other Name, 32.
} 
and a fear that they will lead to an undermining of the Christian's confidence in God. The following chapter considers yet another dimension in evangelical thinking which is provoking much theological debate and is of importance to this study. 


\section{Chapter Four}

\section{CLARK H. PINNOCK, RADICAL INCLUSIVIST}

The third modern evangelical theologian under discussion in this thesis, Clark $\mathrm{H}$. Pinnock, is an inclusivist who displays strong sympathy for certain "pluralistic" ideas. His key work, A Wideness in God's Mercy: The Finality of Jesus Christ in a World of Religions, ${ }^{1}$ presents arguments which soften some traditionally-held evangelical viewpoints. While Pinnock does not support the pluralist stance which denies the uniqueness and finality of Jesus Christ, he does share the pluralistic emphasis on the universal love of God. The challenge, then, is what to make of the implication that salvation must be accessible for all people. ${ }^{2}$ Is confession of Jesus essential to salvation? Pinnock promotes ideas which have disturbed the evangelical world. He has been described as "one of the most stimulating, controversial and influential evangelical theologians." ${ }^{3}$ While some seriously question the appropriateness of labeling him "evangelical", Pinnock desires to be regarded as such. The points of contention have related to his understandings of the doctrine of God, as in his treatment of the "openness of God", 4 the effectiveness of general

\footnotetext{
${ }^{1}$ Clark H. Pinnock, A Wideness in God's Mercy: The Finality of Jesus Christ in a World of Religions (Grand Rapids: Zondervan, 1992).

${ }^{2}$ Ibid., 157.

${ }^{3}$ Daniel Strange, The Possibility of Salvation Among the Unevangelised: An Analysis of Inclusivism in Recent Evangelical Theology (Carlisle, Cumbria: Paternoster Press, 2001), 42.

${ }^{4}$ Clark H. Pinnock, Richard Rice, John Sanders, William Hasker and David Basinger, The Openness of God: A Biblical Challenge to the Traditional Understanding of God (Downers Grove, IL.: InterVarsity Press, 1994).
} 
revelation to those who have never heard the gospel, the possibility of a post-mortem salvation, and the final destiny of the unevangelised.

Pinnock's arguments concerning these issues are the focus of this chapter. They are important because they have been central to debates, particularly in the last three decades, about the nature and shape of the evangelical tradition. "Sometimes," Pinnock observes, "it seems as if Christianity is having to decide again about issues thought to be long settled." ${ }^{, 5}$ He explains that the purpose of his writing A Wideness in God's Mercy was to question restrictivists' thinking and to suggest an optimism of salvation for all humanity. Pinnock admits he is trying to change evangelical thinking, so that the issue of religious pluralism will be placed "on the agenda of evangelical theology. ${ }^{\circ 6}$ His own understanding has developed significantly from his earlier work in the 1970s. It is the purpose of this discussion to focus on the positions he has proposed in the above publication, and developed in more recent works. ${ }^{7}$

\section{Biographical}

Pinnock was born in Toronto in 1937, and brought up by parents who attended the Park Road Baptist Church. He made a personal commitment to Christ while in his very early teens, largely through the influence of his grandmother, living at this time

\footnotetext{
5 Pinnock, "The Finality of Jesus Christ in a World of Religions," in Christian Faith and Practice in the Modern World, ed. Mark A. Noll and David F. Wells (Grand Rapids: Eerdmans, 1988), 153.

${ }^{6}$ Pinnock, A Wideness, 15.

${ }^{7}$ Pinnock, et. al., The Openness of God; Pinnock, ed. The Grace of God and the Will of Man (Minneapolis: Bethany House Publishers, 1995); Flame of Love: A Theology of the Holy Spirit (Downers Grove, IL.: InterVarsity Press, 1996); Most Moved Mover: A Theology of God's Openness (Grand Rapids: Baker Academic, 2001).
} 
in his family's home. ${ }^{8}$ The Park Road Baptist Church, Pinnock recalls, was a "liberal church that had forgotten both the truth and the reality of God pretty much. It was a bore." $\mathrm{He}$ looked outside the Christian influence of his home and found much benefit from literature and religious radio programmes including Charles Fuller's “The Old-Fashioned Revival Hour", and "The Hour of Decision” broadcast by Billy Graham. "Youth for Christ" gatherings, which Pinnock found spiritually beneficial, were held at The Peoples Church, ${ }^{10}$ and he also attended the Canadian Keswick Convention. ${ }^{11}$ These contributed to his commitment to placing Scripture being at the centre of his Christian life. Pinnock was an enthusiast for the InterVarsity Christian Fellowship which was founded in the late 1920s and well established by 1940 . He recalls that he began his theological life "as a Calvinist who regarded alternate evangelical interpretations as suspect and at least mildly heretical. I accepted the

\footnotetext{
${ }^{8}$ Barry L. Callen, Clark H. Pinnock: Journey Toward Renewal (Nappanee, IN.: Evangel Publishing House, 2000), 16. The grandparents, Samuel and Madora Pinnock, were Methodists who had been sent to Nigeria in the 1890s. While working there as missionaries, they had accepted the teaching of water baptism by immersion, subsequently coming under the authority of the United States Southern Baptist mission.

${ }^{9}$ Ibid., 17.

${ }^{10}$ The Peoples Church, Toronto, so named in 1933, was the largest church in Canada. It featured evangelistic crusades and missionary conventions. Until 1959 it was pastored by Oswald J. Smith (1889-1986) who, by that time, had led congregations in Canada for 44 years. He was succeeded by his son, Paul. Oswald Smith was theologically trained at McCormick Theological Seminary, Chicago, 1912. He drew criticism from liberals for his evangelistic crusades, his emphasis on missions and the use of gospel songs. One of his many mottos was "The supreme task of the church is the evangelisation of the world." Oswald J. Smith, The Story of My Life (London: Marshall, Morgan and Scott, 1971), 87-94, 100. See http://www.believersweb.org/view.cfm?ID=130 (accessed 2 February, 2010).

${ }^{11}$ Bebbington, Evangelicalism in Modern Britain, 257-258. The first Convention was in 1875 at Keswick, Lakes District, England. American speakers, Robert and Hannah Pearsall Smith, had taught that a spiritual experience of holy living should follow salvation. John Wesley's belief in "sinless perfection" had paved the way for this new holiness school of thought. The Keswick Convention spread to Canada in the late 1880s.
} 
view I was given that Calvinism was just scriptural evangelicalism in its purest expression and I did not question it for a long time." 12

Pinnock's undergraduate studies were completed at the University of Toronto where his work earned him a scholarship which took him to Britain. His $\mathrm{PhD}$ thesis, completed in 1963 at the University of Manchester, was supervised by F. F. Bruce. Bruce was an influential Brethren scholar, best known for his New Testament theological commentaries. ${ }^{13}$ He had a moderating influence on Pinnock, who in 1971 had published Biblical Revelation: The Foundation of Christian Theology. ${ }^{14}$ This volume was reviewed as upholding the verbal, plenary inspiration of the Bible. Pinnock later explained that this was B. B. Warfield's theology, reinforced by J. I. Packer and then Francis Schaeffer in the 1960s. Bruce reportedly "softened" Pinnock's views as the former took a different stance. That is, he dismissed the fear that "all truth would come into question if the front of inerrancy was lost. This was

\footnotetext{
${ }^{12}$ Pinnock, ed. The Grace of God, 17.

${ }^{13}$ Frederick Fyvie Bruce (1910-1990) was, until 1978, the John Rylands Professor of Biblical Criticism and Exegesis at Manchester University, England. J. J. Scott has described his influence in the following terms: "Best known as a biblical exegete, Bruce published over fifty books, hundreds of articles, essays, and reviews, and edited numerous periodicals, series, and multiple-author volumes. He is one of only two persons to serve as president of both the Society for New Testament Studies and the Society for Old Testament Studies.” J. J. Scott Jr., "Frederick Fyvie Bruce," in Evangelical Dictionary of Theology, $2^{\text {nd }}$ ed., 188-189. Two publications in honour of Bruce were written by his academic colleagues and illustrate the regard in which his work is held. They are: Apostolic History and the Gospel: Biblical and Historical Essays Presented to F. F. Bruce on his $60^{\text {th }}$ Birthday, eds., W. Ward Gasque and Ralph P. Martin (Exeter: Paternoster; Grand Rapids: Eerdmans, 1970), Pauline Studies: Essays Presented to Professor F. F. Bruce on his $70^{\text {th }}$ Birthday, ed. Donald A. Hagner and M. J. Harris (Exeter: Paternoster; Grand Rapids: Eerdmans, (1980).

${ }^{14}$ Pinnock, Biblical Revelation: The Foundation of Christian Theology (Chicago: Moody Press, 1971).
} 
in his opinion, a false mentality." 15 Significantly, one third of Pinnock's dissertation was given over to the topic of the work of the Spirit in believers, and in the church. This was a subject in which he had become interested while studying in Toronto. In later years, the need for renewal through the Spirit was to become his central message to the church. ${ }^{16}$

Pinnock places the church's mission in the world ahead of any critical (or affirming) appraisal of his arguments in order to resolve what he sees as challenging theological questions. He retained his Baptist beliefs while, later, being noted for his ecumenical contacts with "Christians of the East and West, between Calvinists and Wesleyans, conservative Evangelicals and the more dynamic worlds of Pentecostal and Process thought and experience." ${ }^{\prime 17}$ For others, Pinnock is now a polarising influence. Though not his intention, conflicts about Pinnock's views have followed from his desire to "de-emphasise the seeing of evangelicalism as a set creed and [he] would rather see it as more of a spirituality at heart, a particular way of being Christian, a style of religious experience that makes Christ central and has a passion for spreading the good news." 18

\section{Inclusivism and its Appeal}

Pinnock shares the general evangelical disapproval of Hick's model of religious pluralism. Indeed, Pinnock takes him to task for his "impressive attempts" to

\footnotetext{
${ }^{15}$ Callen, Journey Toward Renewal, 58.

${ }^{16}$ Ibid., 31-33.

${ }^{17}$ Ibid., xxi.

18 Ibid.
} 
demolish traditional beliefs, disagreeing with Hick on the three essential Christian doctrines of the Incarnation, the Atonement and the Trinity. Pinnock is blunt, for in his view, liberal Christianity has no future. It is influenced by culture, has nothing to contribute, ruins the churches and robs the world of the gospel. ${ }^{19}$ Pinnock suggests that this would result from people not being told of "the light of the world" and that God has been revealed to the world through Jesus Christ. ${ }^{20}$

Nevertheless, Pinnock's theology sits between inclusivism which accepts the central place of Jesus in God's plan of salvation, and aspects of pluralism which maintain that salvation is available in all religions. Arguably, it is further on the spectrum toward pluralism than fellow inclusivists like Sanders. Among other ideas which will be examined more closely, Pinnock's "wider hope" arguments, including the possibility of an after-death salvation, put him at variance with mainstream evangelicals. Pinnock began to lean towards a "free will theism" in the 1970s. This meant that doctrines such as the immutability of God, for example, were closely scrutinised. The outcome of this will be seen later in Pinnock's argument for the "openness of God." Contrary to the opinion of some evangelicals who want to shelter in the security of views long held, Pinnock sees the new willingness to test evangelical theology, "as being a move towards maturity." 21

\footnotetext{
${ }^{19}$ Pinnock, "Response to John Hick," in More Than One Way? Four Views on Salvation in a Pluralistic World, ed. Dennis L. Okholm and Timothy R. Phillips (Grand Rapids: Zondervan, 1995), 64.

${ }^{20}$ Ibid.

${ }^{21}$ Pinnock, The Grace of God and the Will of Man (Minneapolis: Bethany House, 1995), 30, n19.
} 
A key theological marker for Pinnock is what he sees as the "unbounded generosity of God" as revealed in Jesus. The New Testament clearly teaches the twin truths: God's universal love for humankind and, secondly, the provision for reconciliation of sinners with himself, through the mediation of Christ. In view of universality, Pinnock's questions concern the scope of salvation and the extent to which God's grace reaches humankind and its religions. He deplores the "pessimism of salvation" which, in his opinion, has been passed down from the Augustinian tradition. Pinnock traces the "disaster" of Augustine's version of the doctrine of election which leads the individual to entertain notions of having a favoured status. Rather, Pinnock suggests, God loves the world (universality), and brings election into play with his choosing of "a people, prophets, and apostles in order to implement his love for the entire race." 22

Pinnock writes that the Augustinian thought which produced the pessimistic outlook on salvation, delivered a "package of dismal beliefs." ${ }^{23}$ Despite Christianity's indebtedness to Augustine in many ways, Pinnock states that "something ugly entered Christian theology through Augustine."24 Indeed, Pinnock continues, "his kind of mentality would receive classic expression in this often-quoted statement attributed to a disciple of Augustine's, 'there is no doubt that not only all the heathens, but also all the Jews and all the heretics and schismatics who are outside

\footnotetext{
${ }^{22}$ Pinnock, A Wideness, 25.

${ }^{23}$ Ibid., 39.

${ }^{24}$ Ibid., 40.
} 
the church will go into that everlasting fire prepared for the devils and his angels." 25 Pinnock believes that evangelicals have followed the tradition of Augustine's thinking and have restricted the scope of salvation. Pinnock thus points toward his theory of "wider hope."

Centuries have passed since the time of Augustine, and Pinnock welcomes the new wave of thought which adopts the less restrictive views of the Greek fathers, the most important of which was, for Pinnock, their "optimism of salvation." ${ }^{26} \mathrm{He}$ names Justin Martyr, Clement of Alexandria, Origen, Theophilus of Antioch, and Athenagoras, as theologians who considered the matter of divine election. They believed that election was based on the foreknowledge of God, rather than being a selected number to be saved, chosen before the creation of the world. ${ }^{27}$ This latter view was the Calvinistic idea which Pinnock had known. ${ }^{28}$ The Greek fathers, Pinnock observes, were more lenient to outsiders; instead of displaying a harsh attitude they presented a positive view of the "global reach of God's salvation." 29 Pinnock credits the Second Vatican Council for making the shift from the pessimistic "fewness" doctrine to the recognition of the greater scope of salvation in Christ. He also believes that the Council paved the way to acceptance of inclusivism

\footnotetext{
${ }^{25}$ Pinnock, A Wideness, 40. Quotation attributed to Fulgentius of Ruspe. The statement became incorporated in the Council of Florence (1438-1445).

${ }^{26}$ Ibid., 189, n31.

${ }^{27}$ Ibid., 36-37.

${ }^{28}$ Pinnock, The Grace of God, 19.

${ }^{29}$ Pinnock, A Wideness, 41.
} 
in the denominations. Thus, he is hopeful that extremes of pluralism can be avoided, and the framework of traditional doctrine will be preserved.

In the 1950s, Pinnock was newly Christian, and came under the influence of writers C. S. Lewis and Norman Anderson. The former accepted God's presence in other faiths which, Lewis believed, could lead to salvation, while Anderson used Old Testament figures to suggest the possibility of salvation without Christian confession. ${ }^{30}$ However, Pinnock had read recommended Calvinian theology since his conversion; he knew that Lewis and Anderson's ideas were distinctly suspect among his conservative evangelical fellows. Questions formed in Pinnock's mind concerning the "perseverance of the saints" as it had been expounded to him from the New Testament book of Hebrews. While thinking on the teaching of maintaining union with Christ, Pinnock began to reason that this relationship, in part, depended on human cooperation. The realisation, writes Pinnock, made him "begin to doubt the all-determining fatalistic blue print for history, and to think of God's having made us significantly free creatures, able to accept or reject his purposes for us." ${ }^{31}$

Pinnock records the doctrinal moves he made in the 1970s after much thought and reading on the grace of God. His "first and best discovery" was the lifting of the dark shadow of Calvinian logic. This was, that if God willed everything that took place in the world and if not all human beings will not be saved in the end, then God must have willed it. Labelled by Calvin himself as a "horrible decree," Pinnock admits

\footnotetext{
${ }^{30}$ Norman Anderson, Christianity and the World Religions: The Challenge of Pluralism (Leicester: InterVarsity Press, 1984), 31-32.

${ }^{31}$ Pinnock, The Grace of God, 18.
} 
that this was morally loathsome to him also. ${ }^{32} \mathrm{He}$ felt liberated "to accept the Scriptural teaching of the universal salvific will of God and not feel duty-bound to deny it as before." ${ }^{33}$ Most evangelicals, in Pinnock's opinion, are classed as hardline restrictivists, and he attributes this to Augustine's theology expounded by Calvin. At the same time, Pinnock observes a new conception of the wideness of God's among contemporary evangelicals. He claims to be anxious to foster this development, and replace pessimism of salvation with a biblically-based optimism. Pinnock's conviction is that redemption through Christ is for all; God's generosity revealed to the world in Jesus is unlimited.

\section{The Wider Hope}

Pinnock's affirmation of the theological centrality of God's generosity leads to an examination of his "wider hope" views. These are a crucial dimension of Pinnock's response to pluralism, and are considered in relation to six essential themes: salvation through general revelation; depravity and freedom of will; the substitutionary death of Christ and the doctrine of the Atonement; post-mortem salvation; annihilation and hell; the openness of God.

\section{(1) Salvation Through General Revelation}

Inclusivist views of general revelation were addressed in Chapter Three in relation to Sanders' contention that it is not necessary to know, or understand the work of Christ, in order to be saved by Christ. Pinnock agrees, and is convinced that no one

\footnotetext{
${ }^{32}$ Pinnock, The Grace of God, 19.

${ }^{33}$ Ibid.
} 
will be denied salvation because of a failure, for whatever reason, to hear the gospel. Because, in his view, salvation can be obtained outside of having a faith in Christ, general revelation is "potentially saving knowledge." God is a redemptive God, as well as the God of creation, but the former is not discovered through an awareness of creation only. It is the latter which presents possibilities for humankind to find God at any time. Three Old Testament figures, Job, Enoch and Noah are named as examples of those who are acceptable to God, yet received only general revelation which provides limited knowledge of God. In spite of biblical records, Pinnock does not engage with the possibility that all the above-named received special revelation through particular visitations of God. ${ }^{34}$

While not willing to fully align himself with pluralism's acceptance of other religions as vehicles of salvation, Pinnock comes very close when he writes, "God may use religion as a way of gracing people's lives ... whether God makes use of religion is a contingent matter to be explored case by case by discernment." ${ }^{, 35}$ It is unclear whose discernment is being alluded to at this point in his definition of inclusivism. He is also cautious in suggesting that non-Christian religions may be the "locale of God's grace given to the world because of Christ." 36 Pinnock tentatively opens the door to this pluralistic viewpoint, as explained in relation to Hick's writings in Chapter One. For Pinnock, God is present in non-religious, secular, and

\footnotetext{
${ }^{34}$ Pinnock, A Wideness, 105.

${ }^{35}$ Pinnock, “An Inclusivist View," in More Than One Way?, 100.

${ }^{36}$ Ibid., 98.
} 
non-Christian contexts for the purpose of "preparing the way of the Lord." ${ }^{37} \mathrm{He}$ applauds the Vatican Council for avoiding an "unwarrantedly positive judgment about religion.... That God's dealings with the soul are not restricted to the religious sphere is plain when the Council mentions the salvation of atheists for whom religion is not involved at all." 38 The "wider hope" thus presents many possibilities open to the individual within the confines of general revelation.

\section{(2) Depravity and Freedom of Will}

Pinnock does not agree with the restrictivist view of the total depravity of human nature. "The root problem of the universe," according to the restrictivist, Netland, "is sin; all creation, including humankind, has been corrupted by sin. There is no one who is exempt." ${ }^{39}$ If humanity is totally depraved, Pinnock sees that his inclusivist notion of human freedom is affected and all ability to respond voluntarily to God is removed. Pinnock prefers to explain "depravity" as an individual's progression in sin which varies between persons, and "total" as being at a certain point of sinfulness. Thus, Pinnock is able to retain his belief that individuals are responsible and free, capable of responding to God.

Pinnock attributes this capacity to the prevenient grace of God, that is to say, the grace of God which precedes any human response to God. Prevenient grace is present in all the world, available to humans who have no ability to seek God, nor

\footnotetext{
${ }^{37}$ Pinnock, “An Inclusivist View," 98.

${ }^{38}$ Ibid., 99-100.

${ }^{39}$ Netland, Encountering Religious Pluralism, 318.
} 
ways to assist themselves out of their helpless sinful state. In theological terms, it is that aspect of divine grace which preserves the biblical theme of God as the initiator, and affirms that God's grace can never be earned. The term was originally developed by Augustine who distinguished between prevenient grace (the free gift of God which is proffered before conversion) and subsequent grace, the latter being divinely dispensed after conversion. ${ }^{40}$ In this way Augustine endeavoured to preserve human beings' free will. ${ }^{41}$ For Calvinians, prevenient grace is seen as irresistible; Arminians and Wesleyans believe that the choice to believe in Jesus is left with the individual. ${ }^{42}$ By applying God's prevenient grace to a sinful world, and retaining his belief that depravity is a progression in sin, Pinnock's insistence on the human being's free will (in this case the choice to believe in Jesus) is retained.

\section{(3) The Substitutionary Death of Christ and the Doctrine of the Atonement}

The substitutionary interpretation of the doctrine of the Atonement is an important part of evangelical understanding. It has been termed "a distinguishing mark of the world-wide evangelical fraternity: namely, the belief that Christ's death on the cross had the character of penal substitution, and that it was in virtue of this fact that it brought salvation to mankind." ${ }^{43}$ The substitutionary model of Christ's death and atonement is believed to be central to Paul's thought, as his many statements to the

\footnotetext{
${ }^{40}$ McGrath, Christian Theology, 450.

${ }^{41}$ F. L. Cross, ed. The Oxford Dictionary of the Christian Church, 576.

42 Donald K. McKim, Westminster Dictionary of Theological Terms (Louisville, KY.: Westminster John Knox Press, 1996), 120.

43 J. I. Packer, "What Did the Cross Achieve? The Logic of Penal Substitution," The Tyndale Biblical Theology Lecture (July 1973): 3.
} 
early church convey his conviction that it revealed, supremely, God's love for humankind. That it was sacrificial is suggested by Paul's use of Old Testament typology of the lamb offered for the sins of the people, ${ }^{44}$ for in his death, Christ became the "sin-bearer." George Eldon Ladd explains the traditional evangelical view:

By virtue of the death of Christ, man (sic) is rescued from death; he is acquitted of his guilt and is justified; a reconciliation is accomplished because of which the wrath of God no longer need be feared. The death of Christ has saved the believer from the wrath of God no longer need be feared. The guilt and doom of sin have been borne by Christ; the wrath of God has been propitiated. $^{45}$

In Flame of Love, Pinnock explores the idea of a relational rather than a substitutionary (and in his view, legal) model of atonement. He finds the ideas of substitutionary atonement and the wrath of God inadequate, because the atonement, for him, has God's love rather than God's wrath as its basis. ${ }^{46}$ Pinnock suggests that a "representative and participatory model of atonement" in which God saves humanity by the representative journey of Jesus Christ, would be more credible and faithful to the biblical record. ${ }^{47}$ Broken relationships with God would be more to the fore than God's wrath, for the latter emphasis supports a penal substitutionary death of Jesus model. The "popular view" (presumably meaning the traditional evangelical

\footnotetext{
${ }^{44}$ Rom 3:25; Eph 1:7; Col 1:20.

${ }^{45}$ Ladd, A Theology of the New Testament, 430-431. "Propitiation" is translated in NRSV as "atoning sacrifice." L. Morris explains that "propitiation" is used for the turning away of wrath. He rejects "expiation" as given in some translations, for that is an impersonal term. "Propitiation is a personal term... the biblical way of looking at Christ's saving work is to see it as averting the divine wrath, that is to say, a propitiation." Sinclair B. Ferguson and David F. Wright, eds, New Dictionary of Theology (Leicester: InterVarsity Press, 1998), 608-609.

${ }^{46}$ Callen, Journey Toward Renewal, 129.

${ }^{47}$ Pinnock, Flame of Love, 102-103.
} 
idea) is distorted, Pinnock thinks, for it pictures God as judge and the Son as victim. "It gives the impression," he writes, "that God values his honour more than he values us, and it threatens the unity of Father and Son in the work of atonement."48

Pinnock criticises the traditional view for paying scant attention to the resurrection, and suggests that if this were to be corrected there would be fresh revelation on how Christians are saved by Christ's death. ${ }^{49}$ Here, Pinnock resists what he sees as the "legal dimension" of atonement theology. He argues against this being primarily the work of Christ, but rather, that it was a "power event" and the work of Christ was not "finished" on the cross. ${ }^{50}$ While agreeing that the atoning work of Christ did not end with his death, evangelicalism has historically insisted that Christ's cross displayed a finished work in the perfect sacrifice made once and for all, and that the resurrection is the divine confirmation of the efficacy of Jesus' death. This answers Pinnock's complaint that in "certain juridical models of the atonement, the resurrection has no significance for salvation." 51

Pinnock contends that unless atonement is seen in the context of the representative journey of Jesus, the logic of the substitutionary model will lead "inexorably" to belief in a limited atonement. ${ }^{52}$ Traditionally, evangelicals have maintained that

\footnotetext{
${ }^{48}$ Pinnock, Flame of Love, 102.

${ }^{49}$ Ibid., 98-99.

${ }^{50}$ Ibid., 99.

${ }^{51}$ Ibid.

52 Ibid., 106. "Limited atonement" was one of the articles of faith accepted at the Synod of Dort (1618-1619). Pinnock rejected this doctrine during a change in his theological thinking in the 1970s. See Barry Callen, "From TULIP to ROSE: Clark H. Pinnock on the Open and Risking God," Wesleyan Theological Journal 36 (2001): 160.
} 
Scripture teaches an unlimited atonement; the substitutionary death of Christ was on behalf of all, but effective for those who accept it. Pinnock's concern regarding this issue seems ill-placed, for the idea of limited atonement is that all humankind is not included, even though the atonement is universal in its scope. Universal salvation is not suggested here, for some will reject the offer of Jesus bearing their sin as their substitute. "The participatory model of atonement has a different kind of appeal and rationality from that of the legal theory," Pinnock notes. He does not deny that there is truth in the penal substitutionary model of atonement, but comments that he prefers the analogy of "family room" to the notion of condemnation and the "courtroom." The judge in this case of humanity's need, actually loves and desires the friendship of that same humanity. ${ }^{53}$ The above points are areas of difference between traditional evangelicals and Pinnock's inclusivism.

Pinnock presents three further ideas which give place to freedom of human will, and reinforce his preference for atonement to be based on the love of God rather than on the wrath of God. Thus it is possible to evade reference to sin being more than a "broken relationship and not a state of being or guilt". ${ }^{54}$ This avoids the notion of the separation between God and humanity because of sin, thus involving the sacrificial death of Christ. Pinnock's desire for the roles of God to be re-examined results in an imbalance between "the kindness and the severity of God" (Rom 11:22); God's goodness is favoured to the relative exclusion of God's severity. These notions connect with his more radical inclusivist views of a post-mortem salvation, his

\footnotetext{
${ }^{53}$ Pinnock, Flame of Love, 111.

${ }^{54}$ Sanders, The God Who Risks, 106.
} 
interpretation of eternal punishment, and the openness of God. They are, arguably, the most contentious of Pinnock's ideas which he has sought to introduce to evangelicalism.

\section{(4) The Possibility of Post-mortem Salvation}

The suggestion that post-mortem salvation might be possible is not generally accepted by inclusivists, but is important to Pinnock's wider hope understanding and his view of the openness of God. Pinnock sees logic in the idea, which makes way for certain categories of unevangelised humankind to respond to God's grace after death. Pinnock's definitions of the unevangelised accord with those given by Sanders in the previous chapter. In $A$ Wideness in God's Mercy, Pinnock includes those whose response to God was not ascertained before their death. He quotes Cranfield in saying, "There are those who have died without ever having had a real chance to believe in Christ.... These will not perish eternally without being given, in some way that is beyond our knowledge, an opportunity to hear the gospel and accept him as their Saviour." 55

Pinnock admits that few Scriptures give support to the notion of a post-mortem encounter with Christ, but he suggests that this is partly off-set by good theological argument. The latter statement is debatable, for the "argument" amounts to little more than an idea which centres on God's insight into what an individual's response would have been to his grace, if that one had been afforded an opportunity. Pinnock believes that a post-mortem encounter with Jesus "actually makes very good sense"

\footnotetext{
${ }^{55}$ C. E. Cranfield, “The Interpretation of 1 Pet 3:19 and 4:6," The Expository Times 69 (1958): 372.
} 
for, according to Rom 14:7-12, all will face Jesus, Lord of the dead and the living. "Why," asks Pinnock, "should we think there will be grace for the unevangelised?" The reason he gives is that God does not cease to be gracious or loving to sinners because they are no longer living. He will be a God of mercy and love. ${ }^{56}$ The Scriptures that Pinnock discusses in A Wideness in God's Mercy are acknowledged to be unclear in their meaning, which engenders disputation. For example, Pinnock emphasises 1 Pet 3:19-20, building on Pannenberg's use of that text in support of the notion of a post-mortem encounter. The phrase "and descended into hell" in the Apostles' Creed is based upon this passage. ${ }^{57}$ Pannenberg contends that the passage supports the idea that salvation from future judgment "is still made available to those who during their lifetime encountered neither Jesus nor the Christian message.”58

Yet there is no clear consensus among biblical commentators on 1 Pet 3:19-20. According to Ladd, the teaching of the early church fathers was that Christ preached to the spirits of those who either lived in the days of Noah, or in the time before Christ. This fell out of favour with the early church, Ladd explains, precisely because there was a danger of opening the door to possible salvation after death. He suggests that "preaching" did not involve an offer of salvation, but that it was a triumphant

\footnotetext{
${ }^{56}$ Pinnock, A Wideness, 170.

${ }^{57}$ Ibid., 169.

${ }^{58}$ Wolfhart Pannenberg, The Apostles' Creed in the Light of Today's Questions (Philadelphia: The Westminster Press, 1972), 95. It should be pointed out that "hell" is not mentioned in 1 Pet 3:19-20 and discussion on the terms Hell, Hades, Sheol or Gehenna as used in Scripture will not be undertaken here. It is sufficient to say that evangelicals do not place the Apostles' Creed, nor any other creed, on the level of Scripture.
} 
announcement of Christ's resurrection having broken the power of the spirit world. ${ }^{59}$ The identity of the spirits in prison and the possibilities for a post-mortem salvation are matters of divided opinion among theologians. For example, Tiessen favours the notion that Christ preached through Noah to the people of his day, but notes that "even if 1 Peter 3 teaches that Christ preached to some who had died prior to his own death, we lack any biblical grounds for assuming that a similar post-mortem opportunity is provided for others. ${ }^{, 60}$

Pinnock suggests that an opportunity to repent after death will be there, but it is a moot point as to whether sinners will respond to God any differently from the response they gave during their lifetime. God will not have changed from "love to hate." Those who desire to love God will be welcome to do so. Pinnock argues that some will have sought God while living, while others will be candidates for "updating" their knowledge of God when they have passed into his presence. He sees this as the completion of a faith decision made by those who have moved towards God in their lifetime. "For them," writes Pinnock, "a post-mortem opportunity is firmly established." Pinnock does not express the same confidence for those who have obviously refused God in this life, that is, those who have deliberately "disobeyed the gospel as well as any other form of revelation they have been given. ${ }^{\prime 61}$ The inference is that a post-mortem opportunity will not be afforded them.

\footnotetext{
${ }^{59}$ Ladd, A Theology of the New Testament, 601.

${ }^{60}$ Terrance L. Tiessen, Who Can Be Saved?, 221.

${ }^{61}$ Pinnock, A Wideness, 175.
} 
Pinnock draws upon Rom 14:7-12, which states that each person will be required to give an account of him or herself before the judgment seat of God. In the case of unrepentant sinners, Pinnock agrees that this may not be a "pleasant experience" but he pleads the mercy and grace of a loving God on behalf of the unevangelised. ${ }^{62}$ Other evangelical theologians point out, however, that while God's mercy and grace toward humanity is unquestioned, Rom 11:20-23 speaks of the severity of God, and should not be ignored. ${ }^{63}$ The passage in Rom 14 is not seen as giving any hint of the chance of salvation being offered after death, ${ }^{64}$ while Heb 9:27 asserts strongly that there is finality about death, in that the earthly life that has been lived cannot be changed. ${ }^{65}$

Pinnock holds, then, that knowledge of Jesus or hearing the gospel is not necessary for salvation, which is to say that general knowledge may be sufficient. This being Pinnock's conviction, one can reasonably ask why there is a need to promote the notion of a post-mortem salvation? Pinnock has proceeded much further with this idea than his fellow inclusivists as shown in No Other Name, where Sanders gives an extensive overview of the subject, but rules out Pinnock's position.

Two key theories are employed in Pinnock's treatment of post-mortem evangelisation. He holds to the restrictivist viewpoint of the particularity of salvation

\footnotetext{
${ }^{62}$ Pinnock, A Wideness, 170.

${ }^{63}$ William Edgar, "Exclusivism: Unjust or Just?," in Faith Comes by Hearing, ed. Christopher W. Morgan and Robert A. Peterson (Downers Grove, Il.: InterVarsity Press, 2008), 94; Henry C. Thiessen, Lectures in Systematic Theology (Grand Rapids: Eerdmans, 1983), 389.

${ }^{64}$ Ben Witherington III, Paul's Letter to the Romans: A Socio-Rhetorical Commentary Grand Rapids: Eerdmans, 2004), 336-338.

${ }^{65}$ Thiessen, Lectures in Systematic Theology, 388.
} 
through Christ. ${ }^{66}$ At the same time, he supports the inclusivists' insistence on the value of general knowledge being sufficient to lead the individual to salvation. Pinnock is caught between acknowledging that despite his wider hopes for the unevangelised, the task of spreading the good news (which must be inclusive) is still undiminished. His conviction that God's salvific will is universal, coupled with his belief that God does not have exhaustive foreknowledge, leads him to depend on contested exegesis of 1 Pet 3:19-20. Neither does the notion of "middle knowledge," for Pinnock, assist in solving this problem of the wider hope for the unevangelised. ${ }^{67}$ Pinnock is thus faced with having to maintain the restrictivists' view regarding the central place of Jesus in God's plan of salvation while dealing with the problem of those who have never heard the gospel. ${ }^{68}$ His compromise is to offer the unreached an opportunity after death, which stretches the bounds of inclusivism.

\section{(5) Annihilation and Hell}

Pinnock admits he does not feel calm about the "traditional doctrine of hell" which he believes to mean "everlasting conscious punishment," and suggests that this is probably not what the biblical doctrine means. ${ }^{69} \mathrm{He}$ denies presenting arguments based on sentimentality, or subjective moral outrage. Rather, he advances a view

\footnotetext{
${ }^{66}$ Pinnock, “An Inclusivist View,” 102.

${ }^{67}$ Pinnock, A Wideness, 160-161. Pinnock makes mention of "middle knowledge," that is, the idea that suggests God has knowledge of things which did not, but might have, happened. Pinnock does not subscribe to the notion, however.

${ }^{68}$ Ibid., 17.

${ }^{69}$ Ibid., 157.
} 
which he sees as gaining ground among evangelicals, albeit a "divisive issue" and he pleads for a possible reformation of this particular Christian doctrine. ${ }^{70}$

The term "annihilation" is sometimes used interchangeably with "conditional immortality." However, the latter strictly means that immortality is granted only to those who are redeemed, while the unrepentant cease to exist. The biblical concept of the resurrection of both the unrepentant and redeemed appearing before the judgment seat of Christ is therefore ignored (John 5:29; 2 Cor 5:10). Because Pinnock does not doubt the eschatological Christian doctrine of the resurrection of the body, he states, "I do not call my position conditional immortality."71 Therefore, in line with Pinnock's own vocabulary "annihilation" will be observed in this study.

While Pinnock has pushed the boundaries of inclusivism by offering a post-mortem experience, he by no means embraces universalism, which was discussed in Chapter Three. For him, the question of the finally unrepentant and their punishment still remains unaddressed. Therefore, Pinnock further extends inclusivist thought by promoting the idea of annihilation. This is, in his view, more biblical: rather than punishment that lasts forever God will "declare his judgment upon the wicked and condemn them to extinction which is the second death (Rev 20:11-15).,72

\footnotetext{
${ }^{70}$ Pinnock, "The Destruction of the Finally Impenitent," Criswell Theological Review 4 (1990): 246247.

${ }^{71}$ Ibid.

${ }^{72}$ Pinnock, “Fire, Then Nothing," Christianity Today (March 1987): 40.
} 
The notion of annihilation was mooted by the theologian, Arnobius, in the fourth century, but failed to gain ground. ${ }^{73}$ It surfaced again in the nineteenth century in an attempt to find a middle ground between the orthodox doctrine of eternal punishment and that of universalism, which holds that all, including the devil, will ultimately be saved. In the 1980s, the leading British evangelical John Stott was writing in support of the idea that the punishment of unrepentant human beings may not, in fact, be unending. In his correspondence with David Edwards, Stott admits that "the [unending] concept was intolerable" but that, as an evangelical, "my question must be ... what does God's word say?"74 Stott suggests that biblical material should be studied afresh and differences debated. It is understandable that Stott's tentative position in Evangelical Essentials, and the like-mindedness of an increasing number of evangelicals, would lend support to the wider hope notions. But it also elicits from the exclusive evangelical, Carson, the following observation: that developments in this doctrinal area "reflect greater diversity, greater pluralism if you will, than anything the movement experienced half a century ago." 75

The doctrine of hell is "difficult" but Carson notes that Jesus, who spoke of it more often than any other biblical figure, used the most "graphic language" in his many references. Therefore, it is necessary, Carson suggests, to make every endeavour to

\footnotetext{
${ }^{73}$ F. L. Cross, ed., The Oxford Dictionary of the Christian Church (Oxford: Oxford University Press, 1958), 90. Arnobius (d. ca. 330) is said to be the sole supporter of this opinion. He was an African Christian apologist and produced a treatise full of "curious learning, defending the consonance of the Christian religion with the best pagan philosophy."

${ }^{74}$ David L. Edwards and John Stott, Evangelical Essentials: A Liberal-Evangelical Dialogue (Downers Grove, IL.: InterVarsity Press, 1988), 314-315.

${ }^{75}$ Carson, The Gagging of God, 443.
} 
understand the Scriptures. He admits that this process is painful, and urges that all preaching and discussion on these "distressing themes" should be born out of compassion for sinners that they might "take refuge in the redeeming grace of the gospel." ${ }^{, 76}$ Pinnock, on the other hand, denounces the traditional doctrine of hell, labelling it "an outrageous doctrine, a theological and moral enormity, a bad doctrine of the tradition that needs to be changed." ${ }^{, 77}$ He points out that the doctrine of hell and punishment is not the first tradition to be revisited and challenged, therefore, his annihilation theory is an effort to begin the process of change. Moreover, evangelicals cannot legitimately argue that this particular doctrine must be retained because of tradition. Pinnock notes that, in company with traditionalists, he respects biblical authority, but in this case, their interpretation of Scripture is questioned. $^{78}$

The central questions Pinnock poses are: (a) should Christian theology contend that the finally impenitent will suffer everlasting punishment in body and soul, or, (b) are they more likely to be destroyed in the destruction of a second death? ${ }^{79}$ Augustine is again in the forefront of Pinnock's dissatisfaction with tradition, as it was he who mapped out the guidelines which remained in place for centuries. Orthodoxy includes the doctrine of the nature of hell, and a rejection of the wider hope, while

\footnotetext{
${ }^{76}$ Carson, The Gagging of God, 529.

${ }^{77}$ Pinnock, "The Destruction," 246.

${ }^{78}$ Clark Pinnock, "The Conditional View," in Four Views on Hell, ed. William Crockett (Grand Rapids: Zondervan, 1996), 158.

${ }^{79}$ Pinnock, "The Destruction," 247.
} 
Pinnock promotes notions of universal access to salvation which he sees as providing an avoidance of the "monstrosity" of hell. ${ }^{80}$

In 1987, Pinnock published an article in Christianity Today in which he explains Matt 25:46 as an example of his notion of "fire, then nothing." " "The dread possibility in Matt 10:28," writes Pinnock, "is surely the annihilation and extinction of the whole human person subject to this judgment." 82 In his view this is final, irrevocable, definitive death, rather than the action of an "endlessly vindictive" deity. ${ }^{83}$ There is no point, Pinnock argues, in an everlasting punishment that could never lead to anything good, and this notion is out of line with God's love revealed in the gospels. ${ }^{84}$ He claims that believers will be granted eternal life, and unbelievers will be annihilated at the second death. The eternal punishment idea, Pinnock argues, has come from the Greek view of the natural immortality of the soul. But one needs to think biblically, and so see human beings as mortal, needing to be given eternal life "if they are to have it." 85

Pinnock has not revised these ideas in A Wideness, but rather, reinforced them by suggesting that the erroneous doctrine of universalism would be a choice some would want to make, in order to avoid the doctrine of the eternal punishment of

\footnotetext{
${ }^{80}$ Pinnock, "The Conditional View," 166.

${ }^{81}$ Pinnock, "Fire, Then Nothing," 40-41.

${ }^{82}$ Ibid., 40.

${ }^{83}$ Ibid.

${ }^{84}$ Pinnock, “The Conditional View," 153.

${ }^{85}$ Pinnock, "Fire, Then Nothing," 41.
} 
hell. ${ }^{86}$ Subsequently, Pinnock wrote: "I realise that in interpreting hell as annihilation, I am adopting a minority view among evangelicals and placing myself at risk among them." ${ }^{, 87}$

Briefly, the works of two exegetes differ from Pinnock on the matter of duration of punishment. Gerhard Kittel translates the Greek word apollumi (to destroy) which is used in the Scriptures (noted below) as meaning loss, or to suffer loss, hopeless destiny of death, to make completely inoperative, to put out of use. ${ }^{88}$ With reference to verses which speak of "destruction" and "perdition" Kittel explains, "what is meant here is not a simple extinction of existence, but an everlasting state of torment and death." ${ }^{89}$ He points out that the New Testament gives a central place to the contrast between life and death. Destruction is definitive "not merely in the sense of physical existence, but rather as an eternal plunge into Hades, and a hopeless destiny of death. ${ }^{90}$ Horst Balz and Gerhard Schneider concur, ${ }^{91}$ and cite several references in Mark, Luke and Jude, ${ }^{92}$ giving the meaning of "destroy" thus: to put out of the way entirely, abolish, put an end to, ruin.

\footnotetext{
${ }^{86}$ Pinnock, A Wideness, 156-157.

${ }^{87}$ Pinnock, "The Conditional View," 161.

${ }^{88}$ Gerhard Kittel, ed. Theological Dictionary of the New Testament, Vol. 1, trans. by Geoffrey W. Bromiley (Grand Rapids: Eerdmans, 1964), 394-397; cf. John 17:12; 2 Thess 2:3; 2 Pet 2:1, 3; 3:7; 3:16; Rev 17:8, 17:11.

${ }^{89}$ Ibid., 397; cf. Matt 7:13; Phil 1:28; 3:19; 1 Tim 6:9.

${ }^{90}$ Ibid., 396.

${ }^{91}$ Horst Balz and Gerhard Schneider, eds, Exegetical Dictionary of the New Testament, Vol. 3 (Grand Rapids: Eerdmans, 1999), 622-623.

${ }^{92}$ Mark 1:24; Luke 4:34; 17:27, 29; Jude 5.
} 
Pinnock notes that the Bible gives very little "precise information" on the subject, but concedes that biblical language indicates death and perishing. He suggests a "final and never-changing judgment" rather than eternal punishment. ${ }^{93}$ Pinnock turns from the traditional teaching on the nature of hell as punishment from God, and places the onus on the freedom of the individual. Because God respects the choices of humankind, Pinnock explains, God is morally justified in the destruction of the wicked, ${ }^{94}$ but the idea that hell begins an immortal life of punishment is rejected and Pinnock argues that hell is the "end of a life in rebellion." 95 Human choice is in the forefront of Pinnock's arguments. The relationship with God, as well as the final destiny of human beings, Pinnock explains, "are chosen by ourselves and not thrust upon us. God does not purpose to condemn anyone, but anyone can choose rejection." 96

\section{(6) The Openness of God}

This sixth dimension of Pinnock's "wider hope" theory has tested inclusivist thought and disturbed the evangelical concept of the doctrine of God thus contributing to the process of fragmentation within the evangelical movement. In the early 1980s, Pinnock records that the classical model of Christian theism, "largely thought out by Augustine and with the influence of Greek philosophy," altered the biblical portrayal

\footnotetext{
${ }^{93}$ Callen, Journey Toward Renewal, 165.

${ }^{94}$ Pinnock, "The Conditional View," 151.

${ }^{95}$ Ibid., 137.

${ }^{96}$ Pinnock, A Wideness, 156.
} 
of God. ${ }^{97}$ Therefore, he was faced with re-thinking the doctrine of God, particularly with regard to divine sovereignty and fellowship between God and his free will creatures. The example of Augustine was an encouragement to Pinnock, however, for the latter comments, "If an Augustine had the courage to deal with the culture of his day, and come up with some dazzling new insights, then we can do the same in our own setting." 98 On the other hand, the endeavour to understand the biblical view of God is no insignificant matter. Pinnock wrestled with the "received doctrine of God" by which he meant the classical theistic view. The areas he and Sanders found which needed to be revisited have been reviewed in Chapter Three - divine immutability, the timelessness of God, and divine omniscience. ${ }^{99}$

By the mid-1990s Pinnock had formed the opinion that classical theism stressed the power of God, his eternity and immutability, to the detriment of Pinnock's preferred perception of God. That is, he saw a dynamic dimension to the nature of God, the choice to give true freedom to humankind, and willingness not only to affect, but to be vulnerable to, and affected by, human decisions. ${ }^{100}$ In other words, the "openness

\footnotetext{
${ }^{97}$ Douglas F. Kelly, “Afraid of Infinitude,” Christianity Today (January 1995): 32. Kelly disagrees with this statement. He argues that it is used to dismiss the infinity of God and, thus, the classical model of Christian theism in the matter of the sovereignty of God and his relationship with free will humankind. Kelly argues that Hellenistic terms and concepts were transformed during the early Christian era. He cites Athanasius altering a passage from Plato's Republic. In place of God as "beyond being" Athanasius writes that "God is beyond all created being" which, Kelly believes, is a "profoundly biblical concept."

${ }^{98}$ Pinnock, The Grace of God, 29.

${ }^{99}$ Ibid., 24-26.

${ }^{100}$ Callen, Journey Toward Renewal, 154-155.
} 
of God," he claimed, "is a more biblical understanding of God." He proposed three changes, given below, in order to promote this understanding:

\section{(a) Metaphors}

For biblical understanding, Pinnock suggests that metaphors traditionally used of God should be re-examined. Whereas traditional images of God as "sovereign" and "judge" suggest remoteness and severity, Pinnock argues that more approachable metaphors such as that of the "loving parent" should be applied. "Root metaphors" Pinnock suggests, affect the way individuals relate to God. ${ }^{101}$ The "absolute monarch" model has been changed in Pinnock's perspective to the "loving parent" which 'is at once transcendent, triune, 'open,' and gracefully engaged with a fallen creation."102 However, classical theists argue that the removal of some Scriptural metaphors would produce an unbalanced and unbiblical portrayal of God, emphasising God's love and mercy over justice and righteousness. God thus becomes easier to relate to, which accords with the open theism notions of the "giveand-take relationship" with God, and the adaptation of God's plans to the changing situations which human beings, in their freedom, provoke.

\section{(b) Exhaustive Divine Foreknowledge}

In the second point in his openness of God argument, Pinnock states that the Scriptures do not teach that God has exhaustive divine foreknowledge of the free

\footnotetext{
${ }^{101}$ Pinnock, "Response to Daniel Strange and Amos Yong," in The Evangelical Quarterly 71:4 (1999): 351.

102 Pinnock, "From TULIP to ROSE: Clark H. Pinnock on the Open and Risking God," Wesleyan Theological Journal 36 (2001): 185.
} 
decisions and actions of moral human beings. ${ }^{103}$ While open theists agree that God possesses exhaustive knowledge of the past and present, they disagree with traditional evangelicals by denying God's foreknowledge. This latter point is the main doctrinal platform on which the "openness of God" stands, and is another example of the diversity of beliefs among evangelicals. Open theists point out that the notion of God's exhaustive foreknowledge is incompatible with their conception of human freedom; God cannot know what free moral creatures will choose to do, therefore God does not have exhaustive foreknowledge. This statement questions the wisdom and judgment of God as well as the ability to make perfect decisions. For example, Basinger states, "since God does not necessarily know exactly what will happen in the future, it is always possible that even that which God in his unparalleled wisdom believes to be the best course of action at any given time, may not produce the anticipated results in the long run." ${ }^{\prime 104}$ Pinnock admits that the openness model that he proposes goes further than other versions of the open view in the matter of divine knowledge. However, he points to the Greek fathers "who affirmed genuine human freedom, and a divine/human give-and-take."105 Therefore, Pinnock argues, the openness view is not distanced from the "old traditions of relational theism."106

\footnotetext{
${ }^{103}$ Callen, Journey Toward Renewal, 153.

${ }^{104}$ David Basinger, "Practical Implications," in The Openness of God, 165.

105 Pinnock, "Response to Strange and Yong," in Evangelical Quarterly 71:4 (1999): 353.

106 Ibid.
} 
(c) The Give-and-Take Relationship

In 1994, Pinnock and four like-mined theologians contributed to the publication The Openness of God: A Biblical Challenge to the Traditional Understanding of God. ${ }^{107}$

The writers expressed the premise of their work in these terms:

The Christian life involves a genuine interaction between God and human beings ... God takes risks in this give-and-take relationship ... adapting his own plans to fit the changing situation. God does not control everything that happens. Rather, he is open to receiving input from his creatures. In loving dialogue, God invites us to participate with him to bring the future into being. 108

This does not come about through God imposing his own plan on human beings.

Rather, it is a togetherness which cooperates in mapping the course of one's life; the give-and-take relationship of love. "Open theists," explains Vanhoozer, "want to take seriously (by which they mean literally) the biblical depiction of God's giveand-take relationship with humans." ${ }^{109}$ Open theism does not subscribe to biblical language being dismissed as anthropomorphic, for which they blame Greek philosophical ideas. In the open system, God does not know the future actions of his creatures, but guides and encourages. Neither has God chosen to control every

\footnotetext{
${ }^{107}$ Callen, Journey Towards Renewal, 153, n65. Callen notes that the project of writing Openness of God was originally conceived by John Sanders. Encouraged by Pinnock, Sanders approached the various writers. As Chapter Three of this thesis has indicated, Sanders had come to some of these ideas himself, although he acknowledges the mentoring of Pinnock.

${ }^{108}$ Pinnock, The Openness of God, 7.

${ }^{109}$ Kevin J. Vanhoozer, "The Triune God of the Gospel," in The Cambridge Companion to Evangelical Theology, ed. Timothy Larsen and Daniel J. Treier (Cambridge: Cambridge University Press, 2007), 24.
} 
circumstance in an individual's life in order to bring his purposes to fruition, for this would imply manipulation of those with whom God desires to work in dialogue. ${ }^{110}$

In Pinnock's view, the give-and-take notion flows through to inclusivists' openness to truth found in other traditions. Arguably, Pinnock is the only prominent evangelical who has explored traditions outside "inherited traditions" which were previously untroubled by serious disagreement. Referring to The Documents of Vatican II, Pinnock feels no need of apology as an evangelical in admitting an enormous debt of gratitude to the Second Vatican Council for guidance on the topic of recognising other models of theology. ${ }^{111} \mathrm{He}$ had assumed a position he called "modal inclusivism" which stressed the point that salvation must be universally accessible if God loves the world and Christ died for it, and that elements of other religions could be vehicles of prevenient grace to those who had not heard the Gospel. ${ }^{112}$ Further, Pinnock sees no reason for an atheist not to have faith even though he or she does not understand who God is - a concept outside evangelical thought, and aligned with pluralism. Pinnock's theologies are derived from ideas of the Cappadocian Fathers in the matter of the "social Trinity,"113 the recapitulation, rather than the penal substitutionary doctrine of the atonement, from Irenaeus, ${ }^{114}$ and the idea of theosis, that is, salvation being union with God, from Eastern Orthodoxy.

\footnotetext{
${ }^{110}$ Sanders, The God Who Risks, 287.

${ }^{111}$ Pinnock, “An Inclusivist View,” 97, n4.

112 Strange, "Clark H. Pinnock: The Evolution of an Evangelical Maverick," The Evangelical Quarterly 71:4 (1999): 320-321.

${ }^{113}$ Strange, The Possibility of Salvation, 65.

114 Ibid., 80.
} 
On this last point he writes, "It may be that when we celebrate union with God as the goal of salvation, we have something in common not only with the Eastern churches but also with non-Christian Eastern religions." ${ }^{115}$ Here again, this idea comes close to the pluralists who "urge Christians to move from a Christ-centred faith (that excludes other people) to a God-centred faith."116 This conflicts with the evangelical understanding of salvation being union with Christ, or similarly, the relationship between Christ and believers whereby the benefits of salvation are enjoyed.

The six aspects of Pinnock's wider hope views as given above all question the tenets of orthodox Christianity to some degree. The "openness of God" generates the most serious concerns and debates among evangelicals, first appearing in print as "Divine Foreknowledge and Free-will Theism," in The Grace of God and the Will of Man, five years prior to the publishing of The Openness of God. In this chapter, Richard Rice discusses the difficulties of harmonising human free choice with a doctrine of the exhaustive foreknowledge of God, a major difficulty between traditional evangelicals and open thesis. ${ }^{117} \mathrm{He}$ insists that there is a need for some important aspects of the Christian doctrine of God to be re-interpreted, in order to "enrich" the understanding of divine foreknowledge. ${ }^{118}$ The evangelical "absolutistic" conception of God is a flaw in Christian theism derived from Greek philosophy (discussed in Chapter Three), and in Sanders' view has led to "many problems" in the history of

\footnotetext{
115 Strange, The Possibility of Salvation, 114, n28.

${ }^{116}$ Sanders, No Other Name, 115.

${ }^{117}$ Richard Rice, "Divine Foreknowledge and Free-Will Theism," in The Grace of God and the Will of Man, ed. Clark H. Pinnock (Minnesota: Bethany House Publishers, 1989), 128-139.

${ }^{118}$ Ibid., 134.
} 
the church. ${ }^{119}$ Opposed to these inclusivist stances, Ware has observed that no other branch of orthodoxy or evangelicalism has disputed the doctrine of exhaustive foreknowledge. ${ }^{120}$ However, the denial of the exhaustive foreknowledge of God, as specifically stated in openness doctrine, is necessary to open theists in order to support their view of the future free actions of humankind.

It is the conviction of some evangelicals, even allowing for the many differences between them as mentioned in previous chapters, that the openness of God theories are a re-modelling of the Gospel of Scripture. The proposed new explanations present God as a congenial deity and Pinnock prefers the notion of a "more relational model in which we frame the problems as broken relationships, not divine anger and honour."121

\section{Summary}

Pinnock's changing theological beliefs have engendered debate with those he calls his fellow evangelicals. They have not always been sympathetic and sometimes more than a little antagonistic. It has been shown in this chapter that Pinnock's theology is not aligned to that of the pluralist Hick, since, for example, Pinnock will not give way on the authority of Scripture, the incarnation, the centrality of Jesus, or the Trinity. But it has also been pointed out that Pinnock has expressed ideas to

\footnotetext{
${ }^{119}$ John Sanders, "God as Personal," in The Grace of God and the Will of Man, ed. Clark H. Pinnock (Minnesota: Bethany House Publishers, 1989), 167.

${ }^{120}$ Ware, “Defining Evangelicalism’s Boundaries Theologically,” 194.

${ }^{121}$ Clark H. Pinnock and Robert Brow, Unbounded Love: A Good News Theology for the $21^{\text {st }}$ Century (Downers Grove, IL.: InterVarsity Press, 1994), 103.
} 
which pluralists could relate. Some exclusivist evangelical theologians disown him as being outside the pale of evangelical belief and dismiss his ideas as unscriptural. Others admire the willingness to move beyond notions which Pinnock describes as being supported by "old logic" at the risk of losing traditional evangelical credibility. Pinnock admits to having been frustrated with the lack of voice from among Arminian evangelicals, and he feels the time is past for Calvinists to continue having the upper hand as far as theological teaching in the seminaries is concerned. Not only that, Pinnock believes that leadership of evangelical denominations is largely influenced by Augustinian thinking.

Some writers are opposed to the bold moves Pinnock has made, particularly in his notions of a post-mortem opportunity which widens the scope of salvation, annihilation of the finally impenitent, and his view of hell and punishment. Particularly offensive to exclusivists, but less so to some inclusivists, is the theory Pinnock developed after grappling with the traditional view of omniscience. This "openness of God" theory promotes many notions: God enters into give-and-take relationships with human beings; God takes risks and adapts his own plans to accommodate changes; God seeks the participation of humankind to bring the future into being; God does not have exhaustive knowledge of the future but knows all that is knowable. These ideas are contrary to orthodox evangelical views. Traditionalists consider that they rest on a weak biblical basis and lead to a severely limited concept of God.

It remains a matter of intense debate in evangelicalism as to whether Pinnock has promoted a more biblical understanding of God. And it may be too much for him to 
expect an enthusiastic response to his insights from those who follow an historic tradition passed down, they believe, from the early church. 


\section{Chapter Five}

\section{CONCLUSION}

The preceding chapters have presented the beliefs of three contemporary theologians whose viewpoints range from traditional restrictivism to radical inclusivism which embraces pluralistic ideas. Evangelicalism, as a particular direction found in many denominations held to basic Christian doctrines until relatively recently when aspects of its distinctives were challenged. Many questions arise as to why there is now a call for significant changes in the doctrine of God, perceptions of the scope of salvation, the atoning death of Christ, the final destiny of the unevangelised and the introduction of an "openness of God" theory. Fresh theological ideas have been promoted, due to the focus on the particular problem of the fate of the unevangelised, which has been brought to the forefront of evangelical theology. It is largely the sincere desire to find a way around these questions which has led to the examination of what the Bible teaches and the presentation of notions which have provoked, or pleased, evangelicals. The works of all three theologians have played an important part in urging the evangelical world to strive for biblical answers to these questions. Each of them has made a genuine appeal to, and acknowledgement of, the authority of Scripture in stating their individual views. Even so, core doctrines of orthodox evangelicalism as traditionally defined are under intense scrutiny.

In 1995, Alister McGrath wrote enthusiastically about the future of evangelicalism. At the same time he warned of a danger that it may break up into mutually suspicious splinter groups, each claiming to be the only representation of "true evangelicalism" that others have "sold out" or "betrayed." The threat of evangelical 
rationalism, he believed, was exacerbated by the expansion of evangelicalism in academic circles. ${ }^{1}$ In support of this contention McGrath cited the example of sixteenth century Calvinism when there was optimism pervading the movement, yet within decades, squabbling in their ranks led to "serious long-term division." Although for different reasons, it is evident from the present study that evangelicalism is fragmented; beliefs formerly taken as basic are being challenged. In some areas they are given away. Evangelicalism speaks with one voice in some respects - insisting that Jesus is the only Saviour, on the centrality of the cross, and on the importance of conversion. In other areas, however, evangelicalism presents far less than a united front. For example, there is no single evangelical response on matters such as the doctrine of God or the final destiny of the unevangelised.

The background to the diversifying of traditional evangelicalism has been addressed by Netland in Chapter Two. Netland maintains an exclusivist position, which he regards as both traditional evangelicalism and orthodox Christianity, founded on absolute biblical truth. Together with all evangelicals he agrees that Jesus is the only Saviour. He has also taken seriously God's desire for all to be saved and know the truth, while acknowledging that there are those who have never heard the truth of the Gospel. Netland considers that difficulty in reconciling these problems has assisted the rapid growth of inclusive/pluralistic ideas with respect to the salvific value of non-Christian religions. The demographic fact of increasing cultural pluralism, and changing cultural values generally are also noted. As Netland suggests, Christian believers have responded to these developments by seeking ways whereby adherents to non-Christian beliefs may be presented with an inoffensive Gospel. Consequently,

\footnotetext{
${ }^{1}$ Alister McGrath, Evangelicalism and the Future of Christianity (Downers Grove, Il.: InterVarsity Press, 1995), 189.
} 
he claims that previously non-negotiable doctrines have been revisited, leading to a blurring of the formerly clear lines of evangelical doctrine.

One of Netland's major contributions has been in developing a framework for an evangelical theology of religions, albeit in a tentative and preliminary form. ${ }^{2}$ To Netland, this provides a crucial step for evangelicals - whom he chides for largely avoiding pluralistic questions when faced with other religions. Significantly, Netland frames this whole project by asking whether God has truly revealed himself through Scripture and the beliefs of the Christian church, and the confession and practice of Christians based on the authority of Scripture. If so, he asserts that regardless of secular and non-Christian outlooks, an evangelical theology would need to be built on commitment to Scripture, even if this is not the least offensive line and may therefore be unpalatable to, or incompatible with, non-Christian thought.

Obviously, not every contemporary problem is specifically addressed in the Bible. Answers to some are unclear, still others indicate only principles. Yet Netland's insistence on the centrality of the authority of Scripture is a critical point; it highlights a fundamental element of evangelical identity, but also a central difficulty, since each of the theologians addressed in this thesis makes similar affirmations.

This thesis has argued that the doctrines which have traditionally shaped the evangelical movement are rooted in historical theology, and that the maintaining of these distinctives is a central issue for the continuation of a coherent evangelical movement. It has also highlighted the difficulty of defining evangelicalism solely, or even primarily, in theological terms.

\footnotetext{
${ }^{2}$ Harold Netland, Encountering Religious Pluralism, 308-348.
} 
Theologically, the evangelical movement has emphasised that the sovereign, holy God loves sinful humanity and has planned its salvation: God was in Christ, the only Saviour, whose sacrificial death has made atonement for sin. Evangelicalism has also recognised the authority and sufficiency of Scripture. Third, the need for personal conversion to Christ has been believed and practiced. These theological emphases correspond to three of Bebbington's quadrilateral of evangelical characteristics; they have traditionally comprised the linchpin of evangelicalism, and been supported by orthodox Christian understandings through the centuries. ${ }^{3}$

It is notable that the evangelical theologians addressed in this thesis affirm at least the first two of these emphases. It is only in relation to the third that significant divergence arises. Even here, each asserts the validity and importance of conversion; positions are divided, however, on questions concerning its nature and necessity. While there is clearly variation within the evangelical movement on theological matters, this commonality suggests that the major controlling doctrines remain critical markers of evangelical consciousness and identity. However, when the theological parameters of evangelicalism are more tightly or specifically defined, and especially when questions of "orthodoxy" and tradition are invoked, the lack of theological coherence within evangelicalism becomes more acute.

Even with respect to responses to religious pluralism, theological accord is maintained in a number of matters flowing from the emphases above. For example, exclusivists and inclusivists, radical or otherwise, readily agree on the finality of Christ for salvation. However, inclusivists deem aspects of the exclusivist view too

\footnotetext{
${ }^{3}$ Bebbington, Evangelicalism in Modern Britain, 3.
} 
narrow, so theological discussion develops over salvation being attainable through general revelation and the non-necessity of a personal knowledge of Christ.

On the other hand, inclusivist theologians have clearly adopted a more radical stance on the role of tradition in defining orthodox and evangelical belief - a pattern that has been particularly evident in the debates about open theism. Traditional, or conservative, evangelicals have criticised open theism for bypassing nearly two thousand years of agreement in the Christian church. Further, they argue that it has strained orthodox Christian doctrine by questioning notions of the omniscience and sovereignty of God. For conservative evangelicals, this is tantamount to denying the God of Scripture and creating a god in humankind's own image. Open theism leans closely towards pluralistic disregard for declarations of the unique all-powerful Yahweh in the Old Testament (Isaiah 40-55), which then flows on to the affirmation of Jesus being as unique as Yahweh in the New Testament (Phil 2:5-11). ${ }^{4}$

The breadth of proposed answers to theological questions today has been referred to as the "evangelical big tent". Pinnock, for one, admits to an affinity with this term. While appreciating the liberty it offers, he denies making irresponsible use of it. The "tent" is continuing to enfold developing ideas. Pinnock suggests that in order to promote the wider hope, and the openness of God theories, traditional doctrines have to be re-thought in order to be adjusted or discarded. Claiming to be "an orthodox theologian," positions which do not cohere with orthodox evangelicalism.

\footnotetext{
${ }^{4}$ Wright, The Uniqueness of Jesus, 102.

${ }^{5}$ Pinnock, A Wideness, 40.
} 
Sanders and Pinnock argue that the offer of a wider hope includes those who have not received the message of the Gospel. The incarnation probably is therefore unknown and not understood, which exclusivists argue will endanger an adequate explanation of sin, and the wrath of God which is turned upon it. From that point on, exclusivists fear that little adjustment would be required to deny, or ignore, the necessity of Christ's sacrificial death. In spite of their wider hope ideas, Sanders and Pinnock hold to the uniqueness of Christ as the only Saviour which accords with Sanders' support of "traditional evangelical theology" and Pinnock's claim given above. $^{6}$ Their denial of the epistemological necessity of Jesus, however, places them at the perimeter of evangelical thought.

Again, open theists maintain that God does not have exhaustive foreknowledge because the choices of free humanity have not yet been made. According to Sanders they are "no thing," impossible to be known, even by God. Significant weight is given to the idea that human beings have a part to play in bringing the future into being, together with God. The will of a risk-taking God is often thwarted by the whims and disobedience of human beings, and God is obliged to introduce an alternative plan. In inclusivist thinking, risks which are taken show the willingness of God to partner with freewill humanity. If God is limited in such a way, evangelical exclusivists say their historical orthodox Christian view is being contradicted.

Orthodoxy in the Christian church does not support openness theory. The latter has no platform if it does not deny the foreknowledge of God, but because this denial is propounded, other tenets of the Christian church are adversely affected. The hope

\footnotetext{
${ }^{6}$ Sanders, No Other Name, 32.
} 
expressed by Pinnock that the framework of traditional doctrine will be preserved, is therefore in doubt of being realised. He argues that no evangelical doctrine should be insisted upon simply because it is a tradition. It is rightly pointed out in Most Moved Mover that the traditions of "infant baptism, infused grace through the Eucharist, the celibacy of the priesthood, the theotokos, the images, and a state church that can call councils" have not been followed by evangelicals. ${ }^{7}$ Arguably, this was due to the lack of Scriptural foundation.

Where, then, is the boundary of evangelical theology to be marked? For inclusivists the element of mystery in some biblical doctrines becomes a stumbling-block, the incarnation being a case in point, although Pinnock writes of faith which looks for rational expression, but also "respects mystery." of God as a loving, risk-taking parent will supersede the exclusivist portrayal of the goodness and severity of God. Further, they see the friendly partnering paradigm of God as in line with modern day culture.

In response to such trends, David Wells has argued forcefully that the idea of embracing culture, that is, when it contravenes articles of Christian faith, is neither "neutral" nor "harmless." ${ }^{99}$ Writing in 1993, Wells noted technology as a facet of the culture in which he lived, and while recognising the benefits of the same in the whole of human life, he expressed doubt that culture can be a comfortable partner in the "cause of celebrating Christian truth." The culture of today, Wells observed, is

\footnotetext{
${ }^{7}$ Pinnock, Most Moved Mover, 109.

${ }^{8}$ Robert V. Rakeshaw, “Clark H. Pinnock: A Theological Odyssey,” Christian Scholar's Review 3 (1990): 264.

${ }^{9}$ David F. Wells, No Place for Truth: or, Whatever Happened to Evangelical Theology? (Grand Rapids: Eerdmans, 1993), 11.
} 
inclined to treat "efficient" and "good" as synonymous terms. He would, therefore, dismiss Pinnock's notion of introducing a concept of God simply because it is more attractive to the culture of today. ${ }^{10}$ Furthermore, more conservative evangelicals have been reluctant to adhere to the concept of culture being brought into the theological equation. This cautious approach is based on the perceived need to "sift out truth from local culture."11 It would appear, then, that the material studied in the preceding chapters reveals McGrath's fear of "mutually suspicious groups" as being already a reality.

The final destiny of the unevangelised remains an open debate among both restrictivists and inclusivists and shows no signs of reaching a conclusion to satisfy all evangelical schools of thought. To recapitulate: exclusive evangelicals affirm that explicit knowledge of Jesus, his death and resurrection, and faith in him alone, secures the individual's eternal salvation. Inclusivism agrees that Christ is the only Saviour but, at the same time, expresses an "optimism of salvation" in that explicit knowledge of Jesus is not essential for eternal security. Pluralism denies both of these definitions and maintains that God is revealing himself in all religious traditions. Therefore, the urgency for deciding human beings' final destiny does not arise. In any case, pluralism argues that there is nothing more unique or normative in the person of Jesus than in any other religious leader. Middle knowledge, mentioned briefly in Chapter Four, is ruled out by the writers considered. The option of postmortem evangelism is agreed upon by a relatively small number of evangelicals. Lastly, relativism argues that there is no way to decide on religious truth, and

\footnotetext{
${ }^{10}$ Wells, No Place for Truth, 11.

${ }^{11}$ Carson, The Gagging of God, 539.
} 
questions if there is such a thing. Clearly, the notions advanced into the public arena and the theological world as discussed in this thesis, have failed to achieve agreement.

The limitations of placing theologians in categories, and the difficulties which arise from the diversity within each paradigm, are now widely recognised and have been discussed in Chapter Two. Indeed, the contestation around these issues and extemt pf variation within evangelicalism is striking. It is apparent even in relation to individual evangelical theologians' views. For example, Pinnock describes his own position as restrictive (or exclusive) in that Christ is the Saviour of the world. It is also inclusive because he affirms the grace of God in the wider world. Pinnock admits it is pluralist too, to the extent that he "acknowledges God's gracious work in the lives of human beings everywhere and accepts real differences in what they believe ..." While remaining under the evangelical umbrella, Pinnock's stated purpose is to change evangelical thinking, to retrieve "neglected biblical themes" and find "a new direction for evangelicals." 13

For evangelicals, the religious pluralism debate has largely focused on questions concerning the unevangelised and the saving will of God. It has caused evangelicals to consider their adherence, or otherwise, to historical evangelicalism, and enter into discussion which is based on the authority of Scripture. On some doctrinal matters, this thesis has found that the clarity of evangelical theology has been dimmed. Theologians at various places on the spectrum of the three schools of thought as given in Chapter One have agreed on some areas of belief while others exemplify the

\footnotetext{
${ }^{12}$ Pinnock, A Wideness, 15.

${ }^{13}$ Ibid.
} 
considerable scope in evangelicalism. The ensuing incompatibility of viewpoints underscores the relevance of the topic. Thus, there are continuing endeavours in the theological world to find solutions to the problems discussed and which, at the same time, adhere to Scripture. 


\section{BIBLIOGRAPHY}

\section{Books and Chapters in Books}

Anderson, Norman. Christianity and the World Religions: The Challenge of Pluralism. Downers Grove, IL.: InterVarsity Press, 1984.

Baillie, D. M. God was in Christ. London: Faber and Faber, 1956.

Balz, Horst, and Gerhard Schneider, eds. Exegetical Dictionary of the New Testament, Vol. 3. Grand Rapids: Eerdmans, 1999.

Basinger, David. "Practical Implications." In The Openness of God: A Biblical Challenge to the Traditional Understanding of God, ed. Clark Pinnock, et. al., 155-176. Downers Grove, IL.: InterVarsity Press, 1994.

Bebbington, David W. Evangelicalism in Modern Britain. A History from the 1730s to the 1980s. London: Routledge, 1989.

Berkhof, Hendrikus. Christian Faith: An Introduction to the Study of Faith. Grand Rapids: Eerdmans, 1979.

Bruce, F. F. The Canon of Scripture. Downers Grove, IL.: InterVarsity Press, 1988.

Callen, Barry L. Clark H. Pinnock: Journey Toward Renewal. An Intellectual Biography. Nappanee, IN.: Evangel Publishing House, 2000.

Carson, Donald A. The Gagging of God: Christianity Confronts Pluralism. Grand Rapids: Zondervan, 1996.

Copan, Paul, and Chad Meister, eds. Philosophy of Religion: Classic and Contemporary Issues. Oxford: Blackwell, 2007.

Cross, F. L., ed. The Oxford Dictionary of the Christian Church. London: Oxford University Press, 1963.

D'Costa, Gavin, ed. Christian Uniqueness Reconsidered: The Myth of a Pluralistic Theology of Religions. Maryknoll, NY.: Orbis Books, 1990.

Theology and Religious Pluralism: The Challenge of Other Religions. Oxford: Blackwell, 1986.

Edgar, William. "Exclusivism; Just or Unjust?” In Faith Comes by Hearing, ed. Christopher W. Morgan and Robert A. Peterson, 94-97. Downers Grove, IL.: InterVarsity Press, 2008.

Edwards, David L, and John Stott. Evangelical Essentials: A Liberal-Evangelical Dialogue. Downers Grove, IL.: InterVarsity Press, 1988.

Feinberg, P. D. "Inerrancy and Infallibility of the Bible." In Evangelical Dictionary of Theology, ed. Walter A. Elwell, 156-159. $2^{\text {nd }}$ ed., Grand Rapids: Baker Academic, 2009. 
Ferguson, Sinclair B, and David F. Wright, eds. New Dictionary of Theology. Leicester: InterVarsity Press, 1998.

Fretheim, Tony E. The Suffering of God: An Old Testament Perspective. Philadelphia: Fortress Press, 1984.

Gasque, W. Ward, and Ralph P. Martin, eds. Apostolic History and the Gospel: Biblical and Historical Essays Presented to F. F. Bruce on his $60^{\text {th }}$ birthday. Grand Rapids: Eerdmans, 1970.

Gray, Tony, and Christopher Sinkinson, eds. Reconstructing Theology: A Critical Assessment of the Theology of Clark Pinnock. Carlisle: Paternoster, 2000.

Grenz, Stanley J. Revisioning Evangelical Theology: A Fresh Agenda for the $21^{\text {st }}$ Century. Downers Grove: Intervarsity Press, 1993.

Hagner, Donald A., and M. J. Harris, eds. Pauline Studies: Essays Presented to Professor F. F. Bruce on his $70^{\text {th }}$ Birthday. Grand Rapids: Eerdmans, 1980.

Hall, Christopher A., and John Sanders. Does God Have a Future? A Debate on Divine Providence. Grand Rapids: Baker Academic, 2003.

Hawthorne, Gerald, Ralph P. Martin and Daniel G. Reid, eds. Dictionary of Paul and His Letters. Downers Grove: InterVarsity Press, 1993.

Hick, John. "A Pluralist View." In More Than One Way? Four Views on Salvation in a Pluralistic World, ed. Dennis L. Okholm and Timothy R. Phillips, 29-59. Grand Rapids: Zondervan, 1995.

. "Jesus and the World Religions." In The Myth of God Incarnate, ed. John Hick, 167-185. London: SCM, 1977.

Hick, John, and Paul Knitter, eds. The Myth of Christian Uniqueness: Towards a Pluralistic Theology of Religions. Maryknoll: Orbis Books, 1987.

Hunter, James Davison. Evangelicalism: The Coming Generation. Chicago: Chicago University Press, 1987.

Kittel, Gerhard, ed. Theological Dictionary of the New Testament, Vol. 1. Translated by Geoffrey Bromiley. Grand Rapids: Eerdmans, 1964.

Kraft, Charles. Christianity in Culture: A Study in Biblical Theologizing in CrossCultural Perspective, $2^{\text {nd }}$ ed. Maryknoll, NY.: Orbis Books, 2005.

Kung, Hans. On Being a Christian. Glasgow: William Collins Sons \& Co Ltd., 1974.

Ladd, George Eldon. A Theology of the New Testament. Grand Rapids: Eerdmans, 1979.

Larsen, Timothy, and Daniel J. Treier, eds. The Cambridge Companion to Evangelical Theology. Cambridge: Cambridge University Press, 2007. Evangelical Theology, ed. Timothy Larsen and Daniel Treier,1-14. Cambridge: 
Cambridge University Press, 2007.

. "The Triune God of the Gospel." In The Cambridge Companion to

Evangelical Theology, ed. Timothy Larsen and Daniel Treier, 17-34. Cambridge: Cambridge University Press, 2007.

Lewis, Gordon R. "Impassibility of God." In Evangelical Dictionary of Theology, ed. Walter A. Elwell, 553. $1^{\text {st }}$ ed. Grand Rapids: Baker Book House, 1986.

Marshall, I. Howard. "Incarnational Christology in the New Testament." In Christ the Lord: Studies in Christology presented to Donald Guthrie, ed. Harold H. Rowdon, 2-16. Leicester: InterVarsity Press, 1982.

McGrath, Alister. Christian Theology: An Introduction. $3^{\text {rd }}$ ed. Oxford: Blackwell, 2001.

Evangelicalism and the Future of Christianity. Downers Grove, IL.: InterVarsity Press, 1995.

. "A Particularist View." In More Than One Way? Four Views on Salvation in a Pluralistic World, ed. Dennis L. Okholm and Timothy R. Phillips, 151- 186. Grand Rapids: Zondervan, 1995.

. A Passion for Truth: the Intellectual Coherence of Evangelicalism. Leicester: Apollos, 1986.

McKim, Donald K. Westminster Dictionary of Theological Terms. Louisville, KY.: Westminster John Knox Press, 1996.

Mitchell, J. Jr. “James Innell Packer.” In Evangelical Dictionary of Theology, ed. Walter A. Elwell, 881. $2^{\text {nd }}$ ed. Grand Rapids: Baker Academic, 2009.

Morris, L. L. "Sacrifice." In New Dictionary of Theology, ed. Sinclair B. Ferguson and David F. Wright, 608-609. Leicester: InterVarsity Press, 1998.

Nash, Ronald. Is Jesus the Only Saviour? Grand Rapids: Zondervan, 1994.

Netland, Harold A. Dissonant Voices: Religious Pluralism and the Question of Truth. Vancouver: Regent College Publishing, 1997.

Encountering Pluralism: The Challenge to Christian Faith and Mission. Downers Grove, IL.: InterVarsity Press, 2001.

. "Religious Exclusivism." In Philosophy of Religion: Classic and Contemporary Issues, ed. Paul Copan and Chad Meister, 68-69. Oxford: Blackwell Publishing, 2008.

Okholm, Dennis L., and Timothy R. Phillips, eds. More Than One Way? Four Views on Salvation in a Pluralistic World. Grand Rapids: Zondervan, 1995.

Packer, J. I. God's Words: Studies in Key Bible Themes. Downers Grove, IL.: InterVarsity Press, 1981.

Pannenberg, Wolfhart. "Religious Pluralism and Conflicting Truth Claims.” In 
Christian Uniqueness Reconsidered: The Myth of a Pluralistic Theology of Religions, ed. Gavin d'Costa, 97. Maryknoll, NY.: Orbis, 1990.

The Apostles' Creed in the Light of Today's Questions. Philadelphia: Westminster, 1972.

Pinnock, Clark H. A Wideness in God's Mercy: The Finality of Jesus Christ in a World of Religions. Downers Grove: IL.: InterVarsity Press, 1992.

. "An Inclusivist View." In More Than One Way? Four Views on Salvation in a Pluralistic World, ed. Dennis L. Okholm and Timothy R. Phillips, 95-123. Grand Rapids: Zondervan, 1995.

. Biblical Revelation: The Foundation of Christian Theology. Chicago: Moody Press, 1971.

. "Conclusion." In More Than One Way? Four Views on Salvation in a Pluralistic World, ed. Dennis L. Okholm and Timothy R. Phillips, 141-148. Grand Rapids: Zondervan, 1995.

Flame of Love: A Theology of the Holy Spirit. Downers Grove, IL.: InterVarsity Press, 1996. 2001.

Most Moved Mover: A Theology of God's Openness. Carlisle: Paternoster,

. "Response to John Hick." In More Than One Way? Four Views in Salvation in a Pluralistic World, ed. Dennis L. Okholm and Timothy R. Phillips, 60-64. Grand Rapids: Zondervan, 1995.

. "The Conditional View." In Four Views on Hell, ed. William V. Crockett, John F. Walvoord, Zachary J. Hayes and Clark H. Pinnock, 135-178. Grand Rapids: Zondervan, 1992.

."The Finality of Jesus Christ in a World of Religions." In Christian Faith and Practice in the Modern World, ed. Mark A. Noll and David F. Wells, 152168. Grand Rapids: Eerdmans, 1988.

Pinnock, Clark, ed. The Grace of God and the Will of Man. Minneapolis: Bethany House, 1995.

Pinnock, Clark, Richard Rice, John Sanders, William Hasker and David Basinger, eds. The Openness of God: A Biblical Challenge to the Traditional Understanding of God. Downers Grove, IL.: InterVarsity Press, 1994.

Pinnock, Clark, and Robert Brow. Unbounded Love : A Good News Theology for the $21^{\text {st }}$ Century. Downers Grove, IL.: InterVarsity Press, 1994.

Richard, Ramesh P. The Population of Heaven: A Biblical Response to the Inclusivist Position on Who Will Be Saved. Chicago: Moody Press, 1994.

Richardson, Alan. A Dictionary of Christian Theology. London: SCM Press, 1972.

Rice, Richard. "Divine Foreknowledge and Free-Will Theism." In The Grace of God 
and the Will of Man, ed. Clark Pinnock, 128-139. Minnesota: Bethany House Publishers, 1989.

Sanders, John. "God as Personal." In The Grace of God and the Will of Man, ed. Clark Pinnock, 161-171. Minneapolis: Bethany House, 1995.

. No Other Name: An Investigation into the Destiny of the Unevangelised. Grand Rapids: Eerdmans, 1992.

The God Who Risks: A Theology of Divine Providence. $2^{\text {nd }}$ ed. Downers Grove, IL.: InterVarsity Press, 2007.

Scott, J. J. "Frederick Fyvie Bruce.” In Evangelical Dictionary of Theology, ed. Walter A. Elwell, 188-189, $2^{\text {nd }}$ ed. Grand Rapids: Baker Academic, 2009.

Smith, Oswald J. The Story of My Life. London: Marshall, Morgan and Scott, 1971.

Stewart, James S. A Man in Christ: the Vital Elements of St. Paul's Religion. London: Hodder \& Stoughton, 1964.

Stott, John R. W. Christ the Controversalist. London: Tyndale Press, 1970. 2006.

The Cross of Christ. $20^{\text {th }}$ Anniversary ed. Nottingham : InterVarsity Press,

Strange, Daniel. The Possibility of Salvation Among the Unevangelised: An Analysis of Inclusivisism in Recent Evangelical Theology. Carlisle: Paternoster, 2001.

Strimple, Robert B. "What Does God Know?” In The Coming Evangelical Crisis, ed. John H. Armstrong, 139-153. Chicago: Moody Press, 1996.

Taylor, Justin. "Introduction." In Beyond the Bounds: Open Theism and the Undermining of Biblical Christianity, ed. John Piper, Justin Taylor and Paul Kjoss Helseth, 13-18. Wheaton, IL.: Crossway Books, 2003.

Thiessen, Henry C. Lectures in Systematic Theology. Grand Rapids: Eerdmans, 1983.

Thompson, Mark. "The Uniqueness of Christ as the Revealer of God." In Christ the One and Only: A Global Affirmation of the Uniqueness of Jesus Christ, ed. Sung Wook Chung, 90-109. Grand Rapids: Baker Academic, 2005.

Tiessen, Terrance L. Who Can Be Saved? Reassessing Salvation in Christ and World Religions. Downers Grove, IL.: InterVarsity Press, 2004.

Vanhoozer, Kevin J. "The Triune God of the Gospel." In The Cambridge Companion to Evangelical Theology, ed. Timothy Larsen and Daniel J. Treier, 17-34. Cambridge: Cambridge University Press, 2007.

Wells, David F. No Place for Truth: or, Whatever Happened to Evangelical Theology? Grand Rapids: Eerdmans Publishing Co. 1993.

Wolterstorff, Nicholas. "God Everlasting.” In God and the Good, ed. Clifton J. Orlebeke and Lewis B. Smedes, 181-203. Grand Rapids: Eerdmans, 1975 
Wright, Christopher J. H. Thinking Clearly About the Uniqueness of Jesus, ed. Clive Calver, Thinking Clearly Series. London: Monarch Books, 2001.

Wright, N. T. The Last Word: Beyond the Bible Wars to a New Understanding of the Authority of Scripture. New York: HarperCollins Publishers, 2005.

\section{Internet sources}

Evangelical Alliance. "News Brief." http://www.ekklesia.co.uk/content/news_syndication/article_041115_4754.shtml (accessed 28 March, 2009).

Evangelical Free Church of America. http://www.efca.org/about-efca/our-history (accessed 29 April, 2009).

The Evangelical Alliance Mission. http://www.ministrywatch.com/profile/The-Evangelical-Alliance-Mission.aspx (accessed 2 May, 2009).

Trinity Evangelical Divinity School. http://www.tiu.edu/sfe/pdfs/teds0506app.pdf (accessed 30 April, 2009).

\section{Journals and Book Reviews}

Callen, Barry L. "From TULIP to ROSE: Clark H. Pinnock on the Open and Risking God." Wesleyan Theological Journal 36 (2001): 160-186.

Cranfield, C. E. "The Interpretation of 1 Pet 3: 19 and 4: 6." The Expository Times 69 (1958): 369-372.

Kelly, Douglas F. “Afraid of Infinitude.” Christianity Today (9 January 1995): 33-34.

Neff, David. “Open to Healing.” Christianity Today (January 2004): 21-22.

Netland, Harold. "Exclusivism, Tolerance and Truth.” Missiology XV: 2 (April 1987): 250-251.

Packer, J. I. ““Good Pagans' and God's Kingdom.” Christianity Today (January 17, 1986): 22-25.

. "What Did the Cross Achieve? The Logic of Penal Substitution." Tyndale Bulletin (1974): 3-45.

Pinnock. "Fire, then Nothing." Christianity Today (20 March 1987): 40-41.

. "Response to Daniel Strange and Amos Yong." The Evangelical Quarterly 71:4 (1999): 351- 354.

."The Destruction of the Finally Impenitent." Criswell Theological Review 4 (1990): 243-259.

Rakeshaw, Robert V. "Clark H. Pinnock: A Theological Odyssey." Christian Scholar's 
Review 3 (1990): 264.

Robinson, Bob. "What Exactly is Meant by the 'Uniqueness of Christ?' An

Examination of the Phrase and Other Suggested Alternatives in the Context of Religious Pluralism (Part I)." Evangelical Review of Theology 25 (2001): 362371.

. 'What Exactly is Meant by the 'Uniqueness of Christ?' An Examination of the Phrase and Other Suggested Alternatives in the Context of Religious Pluralism (Part II)." Evangelical Review of Theology 26 (2002): 76-90.

Sanders, John. "Is Belief in Christ Necessary for Salvation?," The Evangelical Quarterly 60 (1988): 241-259.

Strange, Daniel. "Clark Pinnock: The Evolution of an Evangelical Maverick." The Evangelical Quarterly 71:4 (1999): 311-326.

Ware, Bruce A. "Defining Evangelicalism's Boundaries Theologically: Is Open Theism Evangelical?" Journal of the Evangelical Theological Society 45:2 (June 2002): 193-212.

Wright, Christopher J. H. "The Christian and Other Religions." Themelios 9 (February 1984): 1-15. 